


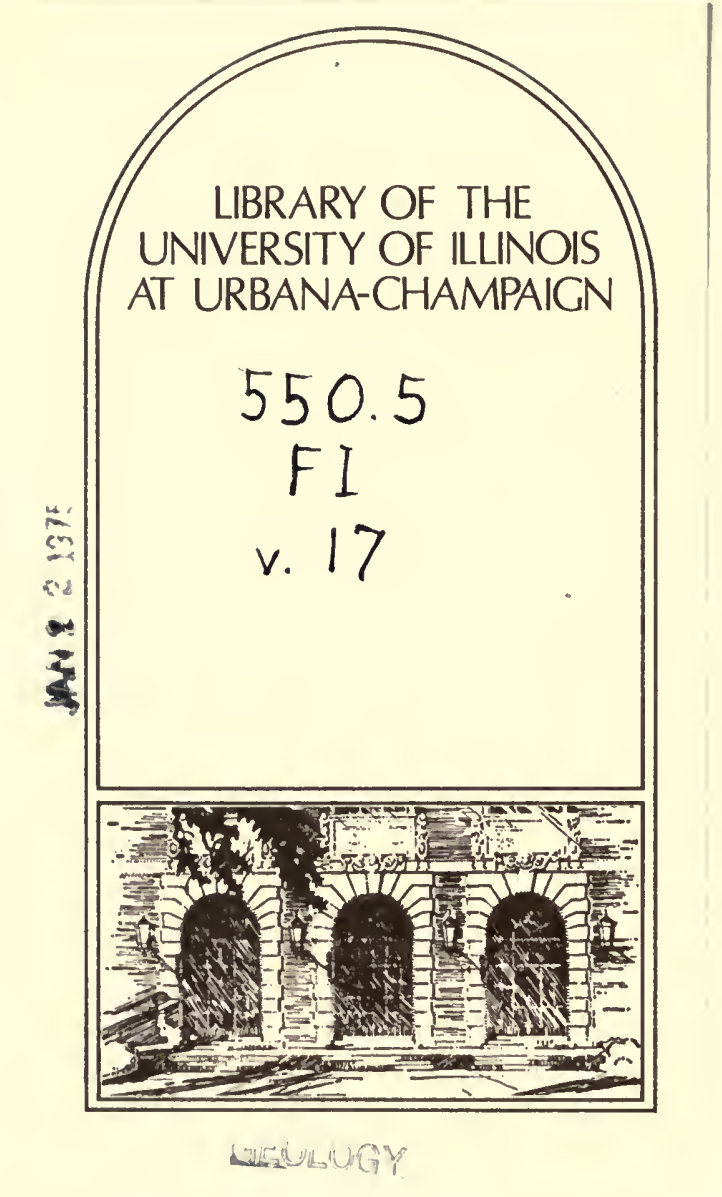

\author{
UNIVERSITY OF \\ ILLINOIS LIBRARY \\ AT URBANA-CHAMPAIGN \\ GEOLOGY
}






CATALOG OF TYPE AND REFERRED SPECIMENS OF FOSSIL OSTRACODES

\title{
IN THE FIELD MUSEUM OF NATURAL HISTORY
}

\author{
MATTHEW H. NITECKI \\ AND \\ DIANA Z. HANDLER
}

\section{The Library of the IMAY 151972 \\ tiniversity of Itlinois at Urbana-Champaien}

\section{-FIELDIANA: GEOLOGY}

VOLUME 17, NUMBER 5

Published by

FIELD MUSEUM OF NATURAL HISTORY

JUNE 17,1968 





\title{
CATALOG OF TYPE AND REFERRED SPECIMENS OF FOSSIL OSTRACODES
}

\section{IN THE FIELD MUSEUM OF NATURAL HISTORY}

\author{
MATTHEW H. NITECKI \\ Assistant Curator, Invertebrate Paleontology \\ AND \\ DIANA Z. HANDLER \\ Assistant, Geology Department
}

FIELDIANA: GEOLOGY

VOLUME 17, NUMBER 5

Published by

FIELD MUSEUM OF NATURAL HISTORY

JUNE 17, 1968 
Library of Congress Catalog Card Number: 68-26379

PRINTED IN THE UNITED STATES OF AMERICA

BY FIELD MUSEUM PRESS 


\section{INTRODUCTION}

This part of the catalog of type specimens of fossil invertebrates lists Paleozoic ostracodes deposited chiefly in the Walker Museum of Paleontology of the University of Chicago, and now housed in the Field Museum of Natural History. Most of these fossils were described by Carey Croneis and his students. In addition, several types belonging to S. A. Miller, Stuart Weller and others are catalogued. Specimens originally deposited in this collection but definitely known to be lost are included. Casts of types not housed in the Field Museum are listed in the Catalog of Casts.

As in previous catalogs, the locality numbers are consecutive and are given in a separate register. Also consistent with former lists is the usage of the word type; only holotypes are recognized, all other "types" are considered "referred specimens."

An attempt has been made to bring the taxonomic positions up to date. The Treatise on Invertebrate Paleontology, the Soviet Treatise (Osnovy paleontologii), and a number of shorter papers have been consulted. However, no pretence of completeness is claimed.

In these references the status of some of the groups included in the catalog has been questioned or changed. The genus Jonesina Ulrich and Bassler, 1908, is placed in Nomina nuda in the Treatise on Invertebrate Paleontology with the statement that "most species referred to this genus belong to Geisina and Hypotetragona" (p. Q413).

Bradorona Matthew, 1903 is referred to Bradoria Matthew, 1899 by Ulrich and Bassler, 1931 (p. 12); by Bassler and Kellett, 1934 (p. 222); by Shimer and Shrock, 1944 (p. 655); and by SylvesterBradley in Moore, 1961 (p. Q102). Aristozoe Barrande, 1868 is referred to Aluta Matthew, 1896 by Ulrich and Bassler, 1931 (p. 49); referred by Rolfe in Moore, 1961 (p. Q429) to phyllocarids. Beyrichona Matthew, 1886,Bradoria Matthew, 1899 and Hipponicharion Matthew, 1886 are referred by Ulrich and Bassler, 1931 (p. 62) to Conchostraca; by Bassler and Kellett, 1934 (pp. 214, 222 and 329) to branchiopods; by Shimer and Shrock, 1944 (pp. 657 and 655) to Archaeostraca. 
In the Russian treatise the following changes in the generic assignments are made: Workmanella Croneis and Gale, 1939, and Pterocodella Croneis and Gale, 1939, are placed in the synonymy of Tetrasacculus Stewart, 1936 (p. 313); Ectodemites Cooper, 1941, and Polytylites Cooper, 1941, are considered subgenera of Amphissites Girty, 1910 (p. 319); Idiomorpha Croneis and Gale, 1939, and Idiomorphina Croneis and Gale, 1939, are placed in the synonymy of Glyptopleura Girty, 1910 (p. 325); Lamarella Croneis and Funkhouser, 1939, is placed in the synonymy of Sansabella Roundy, 1926 (p. 324); the preoccupied Entomis Jones, 1861, is placed in the synonymy of Entomozoe Pribyl, 1950 (p. 330); Golcondella Croneis and Gale, 1939, Kirkbyella Coryell and Booth, 1933, and Verrucosella Croneis and Gale, 1939, are deemed of "unclear systematic position" (p. 413); and Triceratina Upson, 1933, is placed in the synonymy of Monoceratina Roth, 1928 (p. 411).

References to text books have been omitted, even if an illustration of one of our specimens was included. The only exceptions are Pokorný (1965) and Zittel and Eastman (1913). The Ellis and Messina compilation on ostrocodes was not consulted.

Former Walker Museum specimens are identified by the letters UC; the Field Museum of Natural History specimens by the letters P or PE.

We are indebted to Dr. Lois Kent of the Illinois Geological Survey for unravelling the unbelievably complicated Survey localities cited by Croneis and Gutke, 1939, and by Croneis and Bristol, 1939. This paper was supported in part by National Science Foundation grant GB-7197. 


\section{CATALOG OF TYPES}

Aechmina byrnesi (Miller)

See: Leperditia byrnesi Miller, 1874

Aechminella moreyi (Croneis and Funkhouser)

See: Balantoides moreyi Croneis and Funkhouser, 1939

Aechminella reticulatus (Croneis and Thurman)

See: Balantoides reticulatus Croneis and Thurman, 1939

Amphissites bellipunctus Van Pelt, 1933

Holotype: not designated; to be chosen from among UC 38600 ,

UC 38601 and UC 38602, described and illustrated by Van Pelt, 1933, pp. 332-333, pl. 39, figs. 37-40.

Stratigraphic position: Middle Devonian, Bell Shale, Locality 124. Remarks: all specimens consist of single valves only. Referred to Halliella bellipuncta (Van Pelt) by Bassler and Kellett, 1934, p. 322; by Warthin, 1934, p. 208; by Stewart, 1936, p. 746; by Kesling, 1952, p. 26; and by Kesling and Weiss, 1953, p. 35. Referred by Shimer and Shrock, 1944, p. 671, to Kirkbyella bellipuncta (Van Pelt).

Amphissites bicarinatus Croneis and Thurman, 1939

Holotype: by original designation, UC 44509 described and illustrated by Croneis and Thurman, 1939, p. 311, pl. 8, figs. 10-12.

Stratigraphic position: Upper Mississippian, Kinkaid Formation, Locality 147.

Remarks: referred by Cooper, 1941, p. 49, to Ectodemites bicarinatus (Croneis and Thurman).

Amphissites biforatus Croneis and Thurman, 1939

Holotype: by original designation, UC 44510 described and illustrated by Croneis and Thurman, 1939, p. 312, pl. 8, fig. 9 .

Referred specimen: the other specimen, UC 51684, described by Croneis and Thurman, 1939, p. 312. 
Stratigraphic position: Upper Mississippian, Kinkaid Formation, Locality 143.

Remarks: holotype consists of a single valve only. Referred by Cooper, 1941, p. 52, to Polytylites biforatus (Croneis and Thurman).

Amphissites bradfieldi Croneis and Funkhouser in Croneis, 1939

See: Amphissites rothi Croneis and Funkhouser, 1939

Polytylites bradfieldi (Croneis and Funkhouser)

\section{Amphissites carinatus Cooper, 1941}

See: Amphissiles centronotus (Ulrich and Bassler)

\section{Amphissites centronotus (Ulrich and Bassler)}

Referred specimens: UC 37815 described by Kellett, 1933, pp. 9597. The specimens UC 44418 described and illustrated by Croneis and Gale, 1939, p. 270, pl. 5, fig. 9, and cited by Cooper, 1941, pp. 48-49.

Stratigraphic position: UC 37815 Lower Permian, Elmdale Formation, Locality 138; UC 44418 Upper Mississippian, Golconda Formation, Locality 151.

Remarks: UC 37815 consists of five free specimens on slide; three are complete and two are single valves. UC 44418 consists of nine specimens on one slide; the specimen illustrated by Croneis and Gale, 1939, on pl. 5, fig. 9, consists of a single valve. Croneis and Gale, p. 270, assigned the specimens UC 44418 to $A$. centronotus with doubt, and placed a question mark after the species name. The specimens UC 44418 (described by Croneis and Gale) referred by Cooper, 1941, pp. 48-49, to Amphissites carinatus Cooper, 1941 . Cooper, 1946, p. 98, states that the specimen described and illustrated as Amphissites centronotus by Croneis and Gale, 1939, p. 270, pl. 5, fig. 9, is not A. centronotus (Ulrich and Bassler).

Amphissites concavus Croneis and Bristol, 1939

Holotype: by original designation, UC 45118, described and illustrated by Croneis and Bristol, 1939, pp. 79-80, pl. 4, figs. 8-9.

Stratigraphic position: Upper Mississippian, Menard Formation, Locality 168.

Remarks: referred by Cooper, 1941, p. 52, to Polytylites concavus (Croneis and Bristol). 
Amphissites costellifera Croneis and Bristol, 1939

Holotype: lost

Referred specimen: UC 51735 described by Croneis and Bristol, 1939 , p. 80.

Stratigraphic position: Upper Mississippian, Menard Formation, Locality 169.

Remarks: the surviving specimen UC 51735 should be designated holotype. Referred by Cooper, 1941, p. 50, to Ectodemites costilliferus (Croneis and Bristol).

Amphissites dattonensis Harlton, 1927

Referred specimens: UC 37817 described by Kellett, 1933, pp. 9394.

Stratigraphic position: Upper Pennsylvanian, Wabaunsee group, Howard Formation, Locality 131.

Remarks: UC 37817 consists of two free single valves on a slide. Referred by Cooper, 1946, p. 101, to Ectodemites dattonensis (Harlton).

Amphissites decipiens Croneis and Bristol, 1939

Holotype: by original designation, UC 45119 described and illustrated by Croneis and Bristol, 1939, p. 81, pl. 4, fig. 4.

Stratigraphic position: Upper Mississippian, Menard Formation, Locality 169.

Remarks: referred by Cooper, 1941, p. 50, to Ectodemites costelliferus (Croneis and Bristol).

Amphissites diadematus Van Pelt, 1933

Holotype: lost

Referred specimens: UC 38603A - UC 38603G described and illustrated by Van Pelt, 1933, pp. 329-331, pl. 39, figs. 8, 9, 10, 12 and 13. Cited by Stewart, 1936, p. 751 .

Stratigraphic position: Middle Devonian, Bell Shale, Locality 124.

Remarks: all specimens consist of single valves only. Referred by Pokorný, 1965, pp. 190-191, to Arcyzona diademata (Van Pelt). Referred by Stewart, 1936, p. 751, to Amphissites subquadratus (Ulrich). The holotype only referred by Kesling, 1952, p. 31, and by Kesling and Weiss, 1953, p. 51 to Arcyzona diademata (Van Pelt). The specimen figured by Van Pelt, 1933, on 
pl. 39, fig. 8, referred by Kesling, 1952, pp. 32-33, to Arcyzona bythiclimacota Kesling, 1952.

Amphissites elongatus Croneis and Bristol, 1939

Holotype: by original designation, UC 45120 described and illustrated by Croneis and Bristol, 1939, pp. 81-82, pl. 4, fig. 10.

Stratigraphic position: Upper Mississippian, Menard Formation, Locality 170.

Remarks: UC 45120 consists of one valve only. Referred by Cooper, 1941, p. 52, to Polytylites elongatus (Croneis and Bristol).

Amphissites fossilis Croneis and Thurman, 1939

Holotype: by original designation, UC 44511 described and illustrated by Croneis and Thurman, 1939, pp. 312-313, pl. 8, fig. 18 . Stratigraphic position: Upper Mississippian, Kinkaid Formation, Locality 143.

Remarks: referred by Cooper, 1941, p. 52, to Polytylites fossilis (Croneis and Thurman).

Amphissites golcondensis Croneis and Gale, 1939

Holotype: by original designation, UC 44416 described and illustrated by Croneis and Gale, 1939, p. 269, pl. 5, fig. 7 .

Referred specimens: the other two specimens on slide UC 44416 described by Croneis and Gale, 1939, p. 269.

Stratigraphic position: Upper Mississippian, Golconda Formation, Locality 151.

Remarks: UC 44416 consists of three specimens on one slide; holotype consists of a single valve only.

Amphissites grovei Croneis and Gutke, 1939

Holotype: by original designation, UC 45163 described and illustrated by Croneis and Gutke, 1939, pp. 46-47, pl. 2, figs. 28-29. Stratigraphic position: Upper Mississippian, Renault Formation, Locality 182 (published) and 185 (on slide and in Museum catalog).

Remarks: referred by Cooper, 1941, p. 53, to Polytylites grovei (Croneis and Gutke).

Amphissites insignis Croneis and Thurman, 1939

Holotype: by original designation, UC 44512 described and illustrated by Croneis and Thurman, 1939, pp. 314-315, pl. 8, figs. 13-15. 
Stratigraphic position: Upper Mississippian, Kinkaid Formation, Locality 143.

Amphissites latinodus Croneis and Bristol, 1939

Holotype: by original designation, UC 45121 described and illustrated by Croneis and Bristol, 1939, pp. 82-83, pl. 4, fig. 7 .

Stratigraphic position: Upper Mississippian, Menard Formation, Locality 160.

Amphissites lineatus Croneis and Bristol, 1939

Holotype: by original designation, UC 45122 described and illustrated by Croneis and Bristol, 1939, pp. 83-84, pl. 4, figs. 1-2.

Referred specimen: the other specimen UC 51736 described by Croneis and Bristol, 1939, pp. 83-84.

Stratigraphic position: Upper Mississippian, Menard Formation, Localities 164 (UC 45122) and 179 (UC 51736).

Remarks: referred by Cooper, 1941, p. 52, to Polytylites bradfieldi (Croneis and Funkhouser).

Amphissites? obesus Croneis and Gale, 1939

Holotype: by original designation, UC 44419 described and illustrated by Croneis and Gale, 1939, pp. 270-271, pl. 5, figs. 2-3.

Referred specimens: the other three specimens on slide UC 44419 described by Croneis and Gale, 1939, pp. 270-271.

Stratigraphic position: Upper Mississippian, Golconda Formation, Locality 151.

Remarks: UC 44419 consists of four specimens, holotype is a complete carapace; referred specimens are single valves. Referred by Cooper, 1941, p. 50, to Ectodemites obesus (Croneis and Gale).

Amphissites pinguis (Ulrich and Bassler)

Referred specimens: UC 37818 described by Kellett, 1933, pp. 9495.

Stratigraphic position: Lower Permian, Neva Limestone, Locality 139.

Remarks: UC 37818 consists of seven free specimens on slide. One specimen is complete and six are single valves. Referred by Cooper, 1946, p. 102 to Ectodemites geneae (Roth). 
Amphissites rothi Croneis and Funkhouser, 1939

Holotype: by original designation, UC 44463 described and illustrated by Croneis and Funkhouser, 1939, pp. 346-348, pl. 10, fig. 15.

Referred specimens: the other specimens, UC 44483 and UC 51687, described by Croneis and Funkhouser, 1939, pp. 346-348.

Stratigraphic position: Upper Mississippian, Clore Formation, Locality 189.

Remarks: UC 44463 consists of one valve only; UC 44483 consists of 16 specimens on one slide, three are complete and 13 are single valves only; UC 51687 consists of three specimens, one complete carapace and two valves on one slide. Croneis and Funkhouser in Croneis, 1939, p. 29, substituted the new name Amphissites bradfieldi for this species to rectify a homonymy. Referred by Cooper, 1941, p. 52, to Polytylites bradfieldi (Croneis and Funkhouser).

Amphissites similis Croneis and Gale, 1939

Holotype: by original designation, UC 44417 described and illustrated by Croneis and Gale, 1939, pp. 269-270, pl. 5, fig. 6 .

Stratigraphic position: Upper Mississippian, Golconda Formation, Locality 152.

Remarks: UC 44417 consists of a single valve only. Referred by Cooper, 1941, p. 53, to Polytylites similis (Croneis and Gale).

Amphissites (?) simplicissimus Knight, 1928

Referred specimens: UC 37816 described by Kellett, 1933, p. 97. Stratigraphic position: Lower Permian, Elmdale Formation, Locality 138.

Remarks: UC 37816 consists of two free specimens on slide; one is complete and one is a single valve. Referred by Cooper, 1946, pp. 108-109, to Roundyella simplicissima (Knight).

\section{Amphissites sublineatus Croneis and Thurman, 1939}

Holotype: by original designation, UC 44513 described and illustrated by Croneis and Thurman, 1939, pp. 315-316, pl. 8, fig. 16.

Referred specimen: the other specimen, UC 51686, described by Croneis and Thurman, 1939, pp. 315-316.

Stratigraphic position: Upper Mississippian, Kinkaid Formation, Locality 142. 
Remarks: referred by Cooper, 1941, p. 53, to Polytylites sublineatus (Croneis and Thurman).

\section{Amphissites subquadratus Ulrich, 1890}

Referred specimens: UC 38604A and UC 38604B described and illustrated by Van Pelt, 1933, pp. 331-332, pl. 39, figs. 18-20. Stratigraphic position: Middle Devonian, Bell Shale, Locality 128. Remarks: UC 38604A and UC 38604B consist of single valves only. Also see: Amphissites diadematus Van Pelt, 1933.

Amphissites superus Croneis and Gale, 1939

Holotype: by original designation, UC 44421 described and illustrated by Croneis and Gale, 1939, pp. 272-273, pl. 5, figs. 13-14.

Stratigraphic position: Upper Mississippian, Golconda Formation, Locality 156.

Remarks: referred by Cooper, 1941, pp. 53-54, to Polytylites superus (Croneis and Gale).

Amphissites trilobus Croneis and Gale, 1939

Holotype: by original designation, UC 44420 described and illustrated by Croneis and Gale, 1939, pp. 271-272, pl. 5, fig. 5 .

Referred specimens: the other sixteen specimens on slide UC 44420 described by Croneis and Gale, 1939, pp. 271-272.

Stratigraphic position: Upper Mississippian, Golconda Formation, Locality 151.

Remarks: UC 44420 consists of 17 specimens; two specimens are complete, ten specimens are single valves and five are fragments. Referred by Cooper, 1941, p. 54, to Polytylites trilobus (Croneis and Gale).

\section{Amphissites wilsoni Croneis and Gutke, 1939}

Holotype: by original designation, UC 45164 described and illustrated by Croneis and Gutke, 1939, pp. 47-48, pl. 2, figs. 24-25.

Referred specimen: the other specimen UC 51721 described by Croneis and Gutke, 1939, pp. 47-48.

Stratigraphic position: Upper Mississippian, Renault Formation, Locality 180.

Remarks: referred by Cooper, 1941, p. 54, to Polytylites wilsoni (Croneis and Gutke). 
Aparchites? sp.

Referred specimen: P 28878 described and illustrated by Roy, 1941, p. 171, text-figs. $138 \mathrm{a}-\mathrm{c}$.

Stratigraphic position: Upper Ordovician, Richmond, Locality 243. Remarks: P 28878 is a complete carapace slightly damaged along antero-ventral edge.

Arcyzona bythiclimacota Kesling, 1952

See: Amphissites diadematus Van Pelt, 1933

Arcyzona diademata (Van Pelt)

See: Amphissites diadematus Van Pelt, 1933

Bairdia altifrons Knight, 1928

See: Bairdia chasae Kellett, 1934

Bairdia beedei Ulrich and Bassler, 1906

Referred specimens: UC 37910 described by Kellett, 1934, pp. 123125.

Stratigraphic position: Permian, Wreford Formation, Locality 137.

Remarks: UC 37910 consists of four complete specimens and five single valves.

Bairdia cestriensis Ulrich, 1891

See: Bairdia cooperi Croneis and Gale, 1939

Bairdia chasae Kellett, 1934

Referred specimen: UC 37912 described by Kellett, 1934, pp. 135136.

Stratigraphic position: Pennsylvanian, Shawnee Group, Topeka Formation, Locality 194.

Remarks: referred by Cooper, 1946 to Bairdia altifrons Knight, 1928.

Bairdia cooperi Croneis and Gale, 1939

Holotype: by original designation, UC 44439 described and illustrated by Croneis and Gale, 1939, p. 287, pl. 6, figs. 11-12.

Stratigraphic position: Upper Mississippian, Golconda Formation, Locality 153.

Remarks: referred by Cooper, 1941, p. 25, to Bairdia cestriensis Ulrich, 1891. 


\section{Bairdia crassa (?) Harlton, 1929}

Referred specimens: UC 37913 described by Kellett, 1934, p. 129. Stratigraphic position: Middle Pennsylvanian, Iatan Limestone, Locality 193.

Remarks: UC 37913 consists of two complete and one single valve.

\section{Bairdia deloi Kellett, 1934}

Referred specimens: UC 37914 described by Kellett, 1934, pp. 126127.

Stratigraphic position: Permian, Chase Group, Wreford Formation, Locality 196.

Remarks: UC 37914 consists of one complete and one single valve.

Bairdia ? deloi Croneis and Gale, 1939

Holotype: by original designation, UC 44440 described and illustrated by Croneis and Gale, 1939, p. 288, pl. 6, figs. 13-14.

Stratigraphic position: Upper Mississippian, Golconda Formation, Locality 157.

Remarks: Croneis and Gale in Croneis, 1939, pp. 28-29, proposed the new name Bairdia ? osorioi for this species to rectify a homonymy.

Bairdia florenaensis Upson, 1933

Referred specimens: UC 37915, UC 37916 and UC 37917 described by Kellett, 1934, pp. 137-138.

Stratigraphic position: Permian, Chase Group, Wreford Formation, Locality 133 (UC 37915); Elmdale Formation, Locality 138 (UC 37916), and Council Grove Group, Cottonwood Formation, Locality 134 (UC 37917).

Remarks: UC 37915 consists of five complete and five single valves; UC 37916 consists of five complete and one single valve, and UC 37917 consists of four complete and ten single valves.

\section{Bairdia folgeri Kellett, 1934}

Referred specimens: UC 37918 and UC 37919 described by Kellett, 1934, pp. 136-137.

Stratigraphic position: Upper Pennsylvanian, Wabaunsee Group, Howard Formation, Locality 131 (UC 37919) and Howard Formation or Topeka Formation, Locality 201 (UC 37918). 
Remarks: UC 37918 consists of a complete carapace and one valve on one slide; UC 37919 consists of six specimens.

Bairdia galei Croneis and Thurman, 1939

Holotype: by original designation UC 44523 described and illustrated by Croneis and Thurman, 1939, pp. 325-326, pl. 7, fig. 2.

Referred specimen: the other specimen, UC 51685, described by Croneis and Thurman, 1939, pp. 325-326.

Stratigraphic position: Upper Mississippian, Kinkaid Formation, Locality 147.

Bairdia garrisonensis Upson, 1933

Referred specimens: UC 37920 described by Kellett, 1934, p. 134.

Stratigraphic position: Lower Permian, Elmdale Formation, Locality 138.

Remarks: UC 37920 consists of one complete specimen and one single valve.

Bairdia glennensis Harlton, 1927

Referred specimens: two specimens UC 51749 described by Kellett, 1935, pp. 133-134.

Stratigraphic position: Lower Permian, Elmdale Formation, Locality 138.

Remarks: referred by Cooper, 1946, p. 45, to Bairdia cf. B. glennensis Harlton, 1927.

Bairdia cf. B. glennensis Harlton, 1927

See: Bairdia glennensis Harlton, 1927

Bairdia golcondensis Croneis and Gale, 1939

Holotype: by original designation, UC 44438 described and illustrated by Croneis and Gale, 1939, pp. 286-287, pl. 6, figs. 26-27.

Referred specimens: UC 45135 described and illustrated by Croneis and Bristol, 1939, p. 95, pl. 3, fig. 20. UC 45176 and UC 51728 described by Croneis and Gutke, 1939, p. 58; UC 45176 illustrated by them on pl. 2, fig. 23.

Stratigraphic position: Upper Mississippian, UC 44438 from Golconda Formation, Locality 153; UC 45135 from Menard Formation, Locality 176; UC 45176 and UC 51728 from Renault Formation, Locality 182 (published) and 185 (on slides and in Museum catalogs). 
Bairdia hoxbarensis Harlton, 1927

Referred specimens: 12 specimens UC 37911 described by Kellett, 1934, pp. 131-132; specimens PE 12027 cited by Olson, 1946, p. 282.

Stratigraphic position: Middle Pennsylvanian, Stanton Limestone, Locality 141 (UC 37911); and Pennsylvanian, La Salle Cyclothem, Locality 210 (PE 12027).

Remarks: referred by Cooper, 1946, p. 54, to Bairdiacypris nebraskensis (Upson). Slide PE 12027 consists of numerous ostracode specimens from Locality 210.

Bairdia marmorea Kellett, 1934

Referred specimens: seven specimens UC 37921 described by Kellett, 1934, p. 127; specimens PE 12027 cited by Olson, 1946, p. 282.

Stratigraphic position: Lower Permian, Elmdale Formation, Locality 200 (UC 37921), and Pennsylvanian, La Salle Cyclothem, Locality 210 (PE 12027).

Remarks: Slide PE 12027 consists of numerous ostracode specimens from Locality 210.

Bairdia mccoyi Croneis and Gutke, 1939

Holotype: by original designation, UC 45177 described and illustrated by Croneis and Gutke, 1939, p. 59, pl. 2, fig. 15 .

Referred specimen: the other specimen UC 51729 described by Croneis and Gutke, 1939, p. 59.

Stratigraphic position: Upper Mississippian, Renault Formation, Locality 182 (published) and 185 (on slide and in Museum catalogs).

Bairdia ? osorioi Croneis and Gale in Croneis, 1939

See: Bairdia? deloi Croneis and Gale, 1939

Bairdia perincerta Kellett, 1934

Referred specimen: UC 37923 described by Kellett, 1934, p. 132.

Stratigraphic position: Upper Pennsylvanian, Wabaunsee Group, Howard Formation, Locality 131.

Remarks: UC 37923 consists of a single valve only. 
Bairdia pompiliodes Harlton, 1928

Referred specimens: UC 37922 described by Kellett, 1934, pp. 130131.

Stratigraphic position: Lower Permian, Elmdale Formation, Locality 199.

Remarks: UC 37922 consists of two complete specimens and two single valves.

Bairdia renaultensis Croneis and Gutke, 1939

Holotype: by original designation, UC 45178 described and illustrated by Croneis and Gutke, 1939, pp. 59-60, pl. 1, figs. 5-6.

Referred specimen: the other specimen UC 51730 described by Croneis and Gutke, 1939, pp. 59-60.

Stratigraphic position: Upper Mississippian, Renault Formation, Locality 182 (published) and 185 (on slide and in Museum catalogs).

Bairdia reussiana Kirkby, 1858

Referred specimens: seven specimens UC 37928 described by Kellett, 1934, pp. 132-133.

Stratigraphic position: Permian, Chase Group, Fort Riley Limestone, Locality 135.

Bairdia seminalis Knight, 1928

Referred specimens: UC 37924 described by Kellett, 1934, pp. 127128.

Stratigraphic position: Pennsylvanian, Shawnee Group, Deer Creek Formation, top of Ervine Creek Limestone Member, Locality 191.

Remarks: UC 37924 consists of six complete carapaces and five single valves.

Bairdia verwiebei Kellett, 1934

Referred specimens: seven specimens UC 37926 described by Kellett, 1934, pp. 129-130.

Stratigraphic position: Permian, Wreford Formation, Locality 137.

Bairdiacy pris nebraskensis (Upson)

See: Bairdia hoxbarensis Harlton, 1927 
Bairdiolites brevirostris Croneis and Thurman, 1939

Holotype: by original designation, UC 44524A described and illustrated by Croneis and Thurman, 1939, pp. 326-327, pl. 7, fig. 20.

Referred specimen: UC 44524B, described by Croneis and Thurman, 1939, pp. 326-327.

Stratigraphic position: Upper Mississippian, Kinkaid Formation, Locality 150.

Remarks: UC 44524B consists of two complete carapaces.

Bairdiolites bulbosus Croneis and Bristol, 1939

Holotype: by original designation, UC 45136 described and illustrated by Croneis and Bristol, 1939, pp. 95-96, pl. 3, figs. 14-15.

Referred specimen: the other specimen UC 51737 described by Croneis and Bristol, 1939, pp. 95-96.

Stratigraphic position: Upper Mississippian, Menard Formation, Locality 177.

Remarks: Croneis and Bristol, 1939, p. 95, in caption to Bairdiolites bulbosus assign the authorship to Croneis and Gale, n. sp. However, in caption to figs. 14 and 15 on pl. 3, they assign it to Croneis and Bristol. The first entry is assumed to be in error.

Also see: Bairdiolites emarginatus Croneis and Bristol, 1939

Bairdiolites crescentis Croneis and Gale, 1939

Holotype: by original designation, UC 44441 described and illustrated by Croneis and Gale, 1939, pp. 288-289, pl. 6, figs. 19, 20. Cited and illustrated by Shimer and Shrock, 1944, p. 685, pl. 288, figs. 8, 9. Described and illustrated by Pokorný, 1965, p. 241, fig. 881 .

Referred specimens: UC 45137 and UC 51738 described by Croneis and Bristol, 1939, p. 96; UC 45137 illustrated by them on pl. 3 , fig. 18.

Stratigraphic position: Upper Mississippian, UC 44441 from Golconda Formation, Locality 153; UC 45137 Menard Formation, Locality 160; and UC 51738 Menard Formation, Locality 164.

Bairdiolites elongatus Croneis and Funkhouser, 1939

Holotype: by original designation, UC 44471A described and illustrated by Croneis and Funkhouser, 1939, p. 356, pl. 9, figs. $16-$ 17. 
Referred specimen: the other specimen UC 44471B described by Croneis and Funkhouser, 1939, p. 356.

Stratigraphic position: Upper Mississippian, Clore Formation, Locality 187.

Bairdiolites emarginatus Croneis and Bristol, 1939

Holotype: by original designation, UC 45138 described by Croneis and Bristol, 1939, pp. 96-97, pl. 3, figs. 12-13.

Stratigraphic position: Upper Mississippian, Menard Formation, Locality 160.

Remarks: referred by Cooper, 1941, p. 27, to Bairdiolites bulbosus Croneis and Bristol, 1939.

Bairdiolites ovatus Croneis and Funkhouser, 1939

Holotype: by original designation, UC 44472A described and illustrated by Croneis and Funkhouser, 1939, p. 357, pl. 9, figs. 1314. Cited by Cooper, 1941, p. 27.

Referred specimen: the other specimen UC $44472 B$ described by Croneis and Funkhouser, 1939, p. 357.

Stratigraphic position: Upper Mississippian, Clore Formation, Locality 187.

Bairdiolites platypleurus Croneis and Gale, 1939

Holotype: by original designation, UC 44442 described and illustrated by Croneis and Gale, 1939, p. 289, pl. 6, fig. 25.

Stratigraphic position: Upper Mississippian, Golconda Formation, Locality 151.

Balantoides moreyi Croneis and Funkhouser, 1939

Holotype: by original designation, UC 44464 described and illustrated by Croneis and Funkhouser, 1939, pp. 348-349, pl. 10, fig. 16.

Stratigraphic position: Upper Mississippian, Clore Formation, Locality 188.

Remarks: UC 44464 consists of a single valve only. The name Balantoides Morey, 1935, is placed in the synonymy of Aechminella Harlton, 1933, by Sohn in Moore, 1961, p. Q125.

Balantoides reticulatus Croneis and Thurman, 1939

Holotype: by original designation, UC 44514 described and illustrated by Croneis and Thurman, 1939, pp. 316-317, pl. 8, fig. 17. 
Stratigraphic position: Upper Mississippian, Kinkaid Formation, Locality 144.

Remarks: holotype consists of a single valve only. The name Balantoides Morey, 1935, is placed in the synonymy of Aechminella Harlton, 1933, by Sohn in Moore, 1961, p. Q125.

\section{Basslerella crassa Kellett, 1935}

Referred specimens: two specimens UC 51717 described by Kellett, 1935, p. 156.

Stratigraphic position: Lower Permian, Elmdale Formation, Locality 138.

\section{Basslerella firma Kellett, 1935}

Referred specimens: four specimens UC 51718 described by Kellett, 1935 , pp. 156-157.

Stratigraphic position: Lower Permian, Elmdale Formation, Locality 198.

\section{Beyrichia cincinnatiensis S. A. Miller, 1875}

Holotype: UC 8789 described and illustrated by Miller, 1875, pp. 350-351, text-fig. 25; illustrated by Miller, 1889, p. 561, text-fig. 1045 ; described by Ulrich, 1890 , p. 132; described by Cummings, 1908, pp. 1047-1048; illustrated by Bassler in Zittel and Eastman, 1913, fig. 1425b.

Referred specimens: other original specimens on slab UC 8789 described by Miller, 1875, pp. 350-351.

Stratigraphic position: Ordovician, Cincinnatian, Richmond, Locality 230.

Remarks: UC 8789 is a slab of buff limestone $2 \times 9 \times 6.5 \mathrm{~cm}$., containing numerous specimens of Beyrichia cincinnatiensis, and associated invertebrates. Referred to Primitia cincinnatiensis (S. A. Miller), by Miller, 1889, p. 561; Ulrich, 1890, p. 132; Cummings, 1908, pp. 1047-1048; Grabau and Shimer, 1910, p. 345; Bassler in Zittel and Eastman, 1913, p. 738; Ulrich and Bassler, 1923, p. 299; and Hussey, 1926, p. 183 . Referred to Milleratia cincinnatiensis (S. A. Miller) by Swartz, 1936, pp. 543, 544, 567, 568; Shimer and Shrock, 1944, p. 655; Levinson, 1950, p. 69; Levinson, 1951, p. 559; and Levinson in Moore, 1961, p. Q191. 
Beyrichia duryi S. A. Miller, 1874

Holotype: not designated, should be selected from among UC 8878 .

Referred specimens: the original specimens UC 8878 described and illustrated by Miller, $1874 \mathrm{a}$, pp. 232-233, text-figs. 24 and 25; and by Miller, 1889, p. 534, text-figs. 976 and 977.

Stratigraphic position: Ordovician, Cincinnatian, Maysville. Locality 234.

Remarks: UC 8878 consists of one whole carapace, one valve and six fragments. Referred to Ctenobolbina duryi (S. A. Miller) by Ulrich, 1890, p. 108; Ulrich and Bassler, 1908, p. 310; Bassler, 1915, p. 298; and Bassler and Kellett, 1934, p. 251.

Beyrichia gregaria Grubbs, 1939

Holotype: by original designation, UC 46062 described and illustrated by Grubbs, 1939, pp. 559-560, pl. 62, figs. 35, 36 .

Referred specimens: the other four specimens UC 46063 described and illustrated by Grubbs, 1939, pp. 559-560, pl. 62, figs. 37-39.

Stratigraphic position: Silurian, Niagaran Dolomite, Locality 203.

Beyrichia hammelli Miller and Faber, 1894

Holotype: not designated, should be selected from among UC 21709 .

Referred specimens: original specimens UC 21709 described and illustrated by Miller and Faber, 1894, pp. 157-158, pl. 8, fig. 26; by Miller, 1897, p. 787, text-fig. 1458; by Cummings, 1908, pp. 1045-1046, pl. 53, fig. 6; and by Shimer and Shrock, 1944, p. 668 , pl. 281, fig. 66 .

Stratigraphic position: Ordovician, Richmond. Locality 224.

Remarks: UC 21709 is a buff grey, highly fossiliferous, limestone slab, $20 \times 14 \mathrm{~cm}$., containing at least three valves. Specimen from which original drawing was made is not identified. Referred to Ctenobolbina ciliata hammelli (Miller and Faber) by Cummings, 1908, p. 1045. Referred to Ctenobolbina hammelli (Miller and Faber) by Ulrich and Bassler, 1908, p. 310; Bassler, 1915, p. 299; Bassler, 1927, p. 343; Bassler and Kellett, 1934, p. 251; and Shimer and Shrock, 1944, p. 669.

Beyrichia placida Croneis and Gale, 1939

Holotype: by original designation, UC 44410 described and illustrated by Croneis and Gale, 1939, p. 264, pl. 5, fig. 31. 
Stratigraphic position: Upper Mississippian, Golconda Formation, Locality 152.

Beyrichia richardsoni S. A. Miller, 1874

Holotype: UC 8834 described and illustrated by Miller, 1874b, pp. 347-348, text-fig. 40 ; by Miller, 1889 , p. 535, text-fig. 978.

Referred specimens: other original specimens UC 8834 described by Miller, 1874b, pp. 347-348.

Stratigraphic position: Ordovician, Cincinnatian, Richmond, Locality 235.

Remarks: UC 8834 is a slab of fossiliferous limestone $10 \times 6 \mathrm{~cm}$. containing numerous specimens of Beyrichia richardsoni. Referred to Drepanella richardsoni (S. A. Miller) by Ulrich, 1890, p. 117; Ulrich and Bassler, 1908, p. 292; Bassler, 1915, p. 463; and Bassler and Kellett, 1934, p. 205.

Beyrichia tumifrons Hall, 1871

Holotype: UC 52000 described and illustrated by Hall, 1871, pp. 7-8, pl. 4, fig. 11; by Hall, 1872, pp. 231-232, pl. 8, fig. 11; and by Hall and Whitfield, 1875, pp. 102-103, pl. 4, fig. 8 .

Stratigraphic position: Ordovician, Eden, Locality 221.

Remarks: UC 52000 is a slab of grey limestone measuring $9 \times 6 \mathrm{~cm}$. The specimen itself is approximately $0.19 \mathrm{~cm}$. long, marked by a small green diamond. Referred by Bassler, 1915, p. 298, to Ctenobolbina ciliata (Emmons).

Beyrichiopsis cincta (Croneis and Bristol)

See: Denisonia cincta Croneis and Bristol, 1939

Denisonella cincta (Croneis and Bristol)

Beyrichiopsis serrata (Croneis and Thurman)

See: Deloia serrata Croneis and Thurman, 1939

Beyrichiopsis spinosa (Croneis and Bristol)

See: Deloia spinosa Croneis and Bristol, 1939

Beyrichiopsis sulcata (Croneis and Funkhouser)

See: Deloia sulcata Croneis and Funkhouser, 1939

Beyrichiopsis torta (Croneis and Gale)

See: Leightonella torta Croneis and Gale, 1939

Deloia torta (Croneis and Gale) 
Bythocypris clorensis Croneis and Funkhouser, 1939

Holotype: by original designation, UC 44473 described and illustrated by Croneis and Funkhouser, 1939, pp. 357-358, pl. 10, figs. 11-12.

Referred specimens: the other four specimens UC 44485 described by Croneis and Funkhouser, 1939, pp. 357-358.

Stratigraphic position: Upper Mississippian, Clore Formation, Locality 188.

Bythocypris aff. B. cyclindrica (Hall)

Referred specimen: P 28886 described and illustrated by Roy, 1941, p. 176, text-figs. 146a and b.

Stratigraphic position: Upper Ordovician, Richmond, Locality 243. Remarks: $\mathrm{P} 28886$ is a complete carapace.

Bythocypris pediformis Knight, 1928

Referred specimens: UC 51732 described by Kellett, 1935, pp. 135137.

Stratigraphic position: Upper Pennsylvanian, Wabaunsee Group, Howard Formation, Locality 131.

Remarks: UC 51732 consists of 16 complete specimens and three single valves.

Carbonita inflata (Jones and Kirkby)

See: Carbonita (?) tumida (Upson)

Carbonita magna (Upson)

See: Carbonita (?) tumida var. magna (Upson)

Carbonita (?) tumida (Upson)

Referred specimens: two specimens UC 51680 described by Kellett, 1935, pp. 160-161.

Stratigraphic position: Permian, Chase Group, Wreford Formation, Locality 133.

Remarks: referred by Cooper, 1946, p. 66, to Carbonita inflata (Jones and Kirkby).

Carbonita (?) tumida var. magna (Upson)

Referred specimens: two specimens UC 51681 described by Kellett, 1935, p. 161. 
Stratigraphic position: Upper Pennsylvanian, Upper Wabaunsee Group, Falls City Limestone (?), Locality 195.

Remarks: referred by Cooper, 1946, p. 67, to Carbonita magna (Upson).

Carboprimitia depressa Croneis and Funkhouser, 1939

Holotype: by original designation, UC 44452 described and illustrated by Croneis and Funkhouser, 1939, pp. 337-338, pl. 9, figs. 1-2.

Referred specimens: the other five specimens UC 44477 described by Croneis and Funkhouser, 1939, pp. 337-338. UC 45104 and UC 51739 described by Croneis and Bristol, 1939, pp. 70-71. UC 45104 illustrated by them on pl. 3, figs. 1-3.

Stratigraphic position: Upper Mississippian, Clore Formation, Locality 188 (UC 44452); and Menard Formation, Localities 160 (UC 45104) and 178 (UC 51739).

Remarks: UC 44477 consists of three complete and two single valves. The name Carboprimitia Croneis and Funkhouser, 1939, is placed in the synonymy of Sansabella Roundy, 1926, by Sohn in Moore, 1961, p. Q187.

Carboprimitia rotunda Croneis and Funkhouser, 1939

Holotype: by original designation, UC 44453 described and illustrated by Croneis and Funkhouser, 1939, pp. 338-339, pl. 9, figs. 3-4.

Referred specimen: the other specimen UC 44478 described by Croneis and Funkhouser, 1939, pp. 338-339.

Stratigraphic position: Upper Mississippian, Clore Formation, Locality 187.

Remarks: the name Carboprimitia Croneis and Funkhouser, 1939, is placed in the synonymy of Sansabella Roundy, 1926, by Sohn in Moore, 1961, p. Q187.

Carboprimitia rotunda var. tumida Croneis and Funkhouser, 1939.

Holotype: by original designation, UC 44454 described and illustrated by Croneis and Funkhouser, 1939, pp. 339-340, pl. 9, figs. 5-6.

Stratigraphic position: Upper Mississippian, Clore Formation, Locality 187. 
Remarks: the name Carboprimitia Croneis and Funkhouser, 1939, is placed in the synonymy of Sansabella Roundy, 1926, by Sohn in Moore, 1961, p. Q187.

Carboprimitia simulans Croneis and Thurman, 1939

Holotype: by original designation, UC 44503 described and illustrated by Croneis and Thurman, 1939, pp. 303-304, pl. 7, figs. 23-25.

Referred specimens: UC 45105 and UC 51700 described by Croneis and Bristol, 1939, p. 71. UC 45105 illustrated by them on pl. 3, fig. 4. The other original specimens UC 44503 described by Croneis and Thurman, 1939, pp. 303-304.

Stratigraphic position: Upper Mississippian, Kinkaid Formation, Locality 144 (UC 44503); Menard Formation, Locality 161 (UC 45105 and UC 51700).

Remarks: UC 45105 consists of a single valve only. UC 44503 consists of holotype and five other carapaces. The name Carboprimitia Croneis and Funkhouser, 1939, is placed in the synonymy of Sansabella Roundy, 1926, by Sohn in Moore, 1961, p. Q187.

Carboprimitia spinosa Croneis and Bristol, 1939

Holotype: by original designation, UC 45106 described and illustrated by Croneis and Bristol, 1939, pp. 71-72, pl. 3, fig. 8.

Stratigraphic position: Upper Mississippian, Menard Formation, Locality 160.

Remarks: the name Carboprimitia Croneis and Funkhouser, 1939, is placed in the synonymy of Sansabella Roundy, 1926, by Sohn in Moore, 1961, p. Q187.

Cavellina coryelli Croneis and Gale, 1939

Holotype: by original designation, UC 44446 described and illustrated by Croneis and Gale, 1939, pp. 292-293, pl. 5, fig. 18.

Referred specimen: the other specimen on slide UC 44446 described by Croneis and Gale, 1939, pp. 292-293.

Stratigraphic position: Upper Mississippian, Golconda Formation, Locality 151.

Remarks: UC 44446 consists of two specimens on one slide. 
Cavellina edmistonae (Harris and Lalicker)

Referred specimens: eight specimens UC 51715 described by Kellett, 1935, pp. 147-148. PE 12027 cited by Olson, 1946, p. 282. Stratigraphic position: Permian, Chase Group, Fort Riley Limestone, Locality 135 (UC 51715); Pennsylvanian, La Salle Cyclothem, Locality 210 (PE 12027).

Cavellina fittsi Kellett, 1935

Referred specimens: UC 51714 described by Kellett, 1935, p. 147. Stratigraphic position: Upper Pennsylvanian, Wabaunsee Group, Howard Formation, Locality 131.

Remarks: UC 51714 consists of 33 specimens. Thirty specimens are complete and three are single valves.

Cavellina cf. fittsi Kellett, 1935

Referred specimens: PE 12027 cited by Olson, 1946, p. 282.

Stratigraphic position: Pennsylvanian, La Salle Cyclothem, Locality 210.

Remarks: PE 12027 consists of numerous young molts.

Cavellina geisi (Croneis and Gale)

See: Cytherella geisi Croneis and Gale, 1939

Cavellina mediocris Croneis and Thurman, 1939

Holotype: by original designation, UC $44525 \mathrm{~A}$ described and illustrated by Croneis and Thurman, 1939, pp. 327-328, pl. 7, fig. 17.

Referred specimen: UC 44525B, one complete carapace and one valve, described by Croneis and Thurman, 1939, pp. 327-328.

Stratigraphic position: Upper Mississippian, Kinkaid Formation, Locality 144.

Remarks: referred by Cooper, 1941, p. 37, to Cavellina ovatiformis (Ulrich).

\section{Cavellina nebrascensis (Geinitz)}

Referred specimens: eleven specimens UC 51713 described by Kellett, 1935, pp. 146-147. Specimens PE 12027 cited by Olson, 1946, p. 282.

Stratigraphic position: Lower Permian, Elmdale Formation, Locality 200 (UC 51713); Pennsylvanian, La Salle Cyclothem, Locality 210 (PE 12027). 
Cavellina ovalis Croneis and Funkhouser, 1939

Holotype: by original designation, UC 44474 described and illustrated by Croneis and Funkhouser, 1939, p. 358-359, pl. 9, figs. 9-10.

Referred specimens: the other seven specimens, UC 44486 and UC 44486B, described by Croneis and Funkhouser, 1939, pp. 358-359.

Stratigraphic position: Upper Mississippian, Clore Formation, Locality 188.

Remarks: referred by Cooper, 1941, p. 37, to Cavellina ovatiformis (Ulrich).

\section{Cavellina ovatiformis (Ulrich)}

See: Cavellina mediocris Croneis and Thurman, 1939

Cavellina ovalis Croneis and Funkhouser, 1939

Cavellina parallela Croneis and Gutke, 1939

Holotype: by original designation, UC 45182 described and illustrated by Croneis and Gutke, 1939, p. 62, pl. 1, fig. 1 .

Stratigraphic position: Upper Mississippian, Renault Formation, Locality 180.

Cavellina ? perplexa Croneis and Funkhouser, 1939

Holotype: by original designation, UC 44475 described and illustrated by Croneis and Funkhouser, 1939, p. 359, pl. 9, figs. 1920 .

Referred specimens: UC 45115 and UC 51709 described by Croneis and Bristol, 1939, p. 86. UC 45115 illustrated by them, pl. 3, fig. 17.

Stratigraphic position: Upper Mississippian, Clore Formation, Locality 187 (UC 44475); Menard Formation, Localities 171 (UC 45115) and 158 (UC 51709).

Remarks: Croneis and Bristol, 1939, spelled the genus Cavallina. It is considered to be a typographic error.

Cavellina spatulata Croneis and Gutke, 1939

Holotype: by original designation, UC 45181 described and illustrated by Croneis and Gutke, 1939, pp. 61-62, pl. 1, fig. 2.

Referred specimen: the other specimen UC 51731 described by Croneis and Gutke, 1939, pp. 61-62. 
Stratigraphic position: Upper Mississippian, Renault Formation, Locality 184 (published) and 186 (on slide and in Museum catalogs).

\section{Cavellina sp.}

Referred specimens: PE 12028 cited by Olson, 1946, p. 295.

Stratigraphic position: Upper Pennsylvanian, Locality 211.

Chesterella exuta Croneis and Gutke, 1939

Holotype: by original designation, UC 45161 described and illustrated by Croneis and Gutke, 1939, p. 45, pl. 1, figs. 20-21.

Cited and illustrated by Shimer and Shrock, 1944, p. 679, pl. 285, figs. 14, 15.

Referred specimen: the other specimen UC 51759 described by Croneis and Gutke, 1939, p. 45.

Stratigraphic position: Upper Mississippian, Renault Formation, Locality 182 (published) and 185 (indicated on slides and Museum catalogs).

Remarks: the name Chesterella Croneis and Gutke, 1939, is placed in the synonymy of Knoxina Coryell and Rogatz, 1932, by Sohn in Moore, 1961, p. Q186.

\section{Chesterella fissurata Croneis and Gutke, 1939}

Holotype: by original designation, UC 45162 described and illustrated by Croneis and Gutke, 1939, pp. 45-46, pl. 1, figs. 18-19. Described and illustrated by Pokorný, 1965, pp. 211-212, fig. 820 .

Referred specimen: the other specimen UC 51720 described by Croneis and Gutke, 1939, pp. 45-46.

Stratigraphic position: Upper Mississippian, Renault Formation, Locality 184 (published) and 186 (indicated on slides and $\mathrm{Mu}$ seum catalogs).

Remarks: Cooper, 1941, p. 54, questioned the generic designation of Chesterella fissura Croneis and Gutke, 1939. The name Chesterella Croneis and Gutke, 1939, is placed in the synonymy of Knoxina Coryell and Rogatz, 1932, by Sohn in Moore, 1961, p. Q186.

Coelochilina jerseyensis (S. Weller)

See: Eurychilina jerseyensis S. Weller, 1903 
Coelochilina oculifera (S. Weller)

See: Eurychilina oculifera S. Weller, 1903

Cornigella binoda Kellett, 1933

Referred specimen: UC 37819 described by Kellett, 1933, p. 73.

Stratigraphic position: Lower Permian, Chase Group, Fort Riley

Limestone, Locality 135.

Remarks: UC 37819 consists of single valve on slide.

Cornigella golcondensis (Croneis and Gale)

See: Verrucosella golcondensis Croneis and Gale, 1939

Coryellina bicornis (Croneis and Gale)

See: Perprimitia ? bicornis Croneis and Gale, 1939

Coryellina elegans (Croneis and Gutke)

See: Perprimitia elegans Croneis and Gutke, 1939

Remarks: the name Coryellina Kellett, 1935, is placed in the synonymy of Coryellites Kellett, 1936, by Cooper, 1946, p. 55.

Coryellites elegans (Croneis and Gutke)

See: Coryellina elegans (Croneis and Gutke)

Ctenobolbina ciliata (Emmons)

See: Beyrichia tumifrons Hall, 1871

Ctenobolbina ciliata hammelli (Miller and Faber)

See: Beyrichia hammelli Miller and Faber, 1894

Ctenobolbina duryi (S. A. Miller)

See: Beyrichia duryi S. A. Miller, 1874

Ctenobolbina hammelli (Miller and Faber)

See: Beyrichin hammelli Miller and Faber, 1894

Cythere irregularis S. A. Miller, 1878

Holotype: not designated; should be selected from among UC 8874 .

Referred specimens: the original specimens UC 8874 described and illustrated by Miller, 1878, p. 106, pl. 3, figs. 7 and 7a.

Stratigraphic position: Ordovician, Cincinnatian, Locality 233. 
Remarks: UC 8874 consists of three specimens; the smallest, a complete carapace illustrated by Miller; the largest, an almost complete carapace measured by Miller; and a mediumsize complete carapace. The captions to Miller's pl. 3, figs. 7 and $7 \mathrm{a}$ indicate that the illustrations are drawn to scale; however, they are enlarged three times. Referred to Cytheropsis irregularis (Miller) by Miller, 1889, p. 541. Referred to Elpe irregularis (Miller) by Bassler, 1915, p. 476, and by Bassler and Kellett, 1934, p. 297.

\section{Cytherella geisi Croneis and Gale, 1939}

Holotype: by original designation, UC 44445 described and illustrated by Croneis and Gale, 1939, pp. 291-292, pl. 5, fig. 32.

Stratigraphic position: Upper Mississippian, Golconda Formation, Locality 151.

Remarks: referred by Cooper, 1941, p. 36, to Cavellina geisi (Croneis and Gale).

Cytherella quaesita Roth, 1929

Referred specimens: UC 38605A and UC 38605B described and illustrated by Van Pelt, 1933, pp. 341-342, pl. 39, figs. 1, 2.

Stratigraphic position: Middle Devonian, Bell Shale, Locality 124.

Remarks: UC 38605A and UC 38605B are complete specimens on two separate slides.

\section{Cytherella symmetrica Payne, 1937}

Referred specimens: PE 12027 cited by Olson, 1946, p. 282.

Stratigraphic position: Pennsylvanian, La Salle Cyclothem, Locality 210.

Cytherella sp.

Referred specimens: PE 12028 cited by Olson, 1946, p. 295.

Stratigraphic position: Upper Pennsylvanian, Locality 211.

\section{Cytherellina punctulifera (Hall)}

See: Primitiopsis unicornis Van Pelt, 1933

Cy theropsis irregularis (S. A. Miller)

See: Cythere irregularis S. A. Miller, 1878 
Deloia serrata Croneis and Thurman, 1939

Holotype: by original designation, UC 44515 described and illustrated by Croneis and Thurman, 1939, pp. 307-308, pl. 7, figs. $7-10$. Cited and illustrated by Shimer and Shrock, 1944, p. 679, pl. 285, figs. 16-19.

Stratigraphic position: Upper Mississippian, Kinkaid Formation, Locality 148.

Remarks: the name Deloia Croneis and Thurman, 1939, is placed in the synonymy of Beyrichiopsis Jones and Kirkby, 1886, by Sohn in Moore, 1961, p. Q185. Also suggested by Pokorný, 1965, p. 215.

Deloia spinosa Croneis and Bristol, 1939

Holotype: by original designation, UC 45108 described and illustrated by Croneis and Bristol, 1939, pp. 73-74, pl. 3, fig. 21.

Stratigraphic position: Upper Mississippian, Menard Formation, Locality 163.

Remarks: holotype consists of one valve.

Also see: Leightonella torta Croneis and Gale, 1939. The name Deloia Croneis and Thurman, 1939, is placed in the synonymy of Beyrichiopsis Jones and Kirkby, 1886, by Sohn in Moore, 1961, p. Q185.

Deloia sulcata Croneis and Funkhouser, 1939

Holotype: by original designation, UC 44460 described and illustrated by Croneis and Funkhouser, 1939, pp. 344-345, pl. 9, fig. 18.

Stratigraphic position: Upper Mississippian, Clore Formation, Locality 187.

Remarks: UC 44460 consists of one valve only. The name Deloia Croneis and Thurman, 1939, is placed in the synonymy of Beyrichiopsis Jones and Kirkby, 1886, by Sohn in Moore, 1961, p. Q185.

\section{Deloia torta (Croneis and Gale)}

See: Leightonella torta Croneis and Gale, 1939

Beyrichiopsis torta (Croneis and Gale)

Denisonella cincta (Croneis and Bristol)

See: Denisonia cincta Croneis and Bristol, 1939 
Beyrichiopsis cincta (Croneis and Bristol)

Remarks: the name Denisonella Croneis and Bristol, 1942, is placed in the synonymy of Beyrichiopsis Jones and Kirkby, 1886, by Sohn in Moore, 1961, p. Q185; and by Pokorný, 1965, p. 215.

Denisonia cincta Croneis and Bristol, 1939

Holotype: by original designation, UC 45112 described and illustrated by Croneis and Bristol, 1939, pp. 76-77, pl. 4, fig. 13.

Referred specimen: the other specimen UC 51701 described by Croneis and Bristol, 1939, pp. 76-77.

Stratigraphic position: Upper Mississippian, Menard Formation, Locality 165.

Remarks: UC 45112 consists of one valve. The name Denisonia Croneis and Bristol, 1939, is placed in the synonymy of Beyrichiopsis Jones and Kirkby, 1886, by Sohn in Moore, 1961, p. Q185, and by Pokorný, 1965, p. 215. Croneis and Bristol, 1942 , p. 777 , proposed the new generic name Denisonella, to rectify a homonymy.

\section{Dicranella? byrnesi (S. A. Miller)}

See: Leperditia byrnesi S. A. Miller, 1874

Discoidella pendens Croneis and Gutke, 1939

Holotype: by original designation, UC 45166 described and illustrated by Croneis and Gutke, 1939, p. 49, pl. 2, fig. 20.

Referred specimen: the other specimen UC 51723 described by Croneis and Gutke, 1939, p. 49.

Stratigraphic position: Upper Mississippian, Renault Formation, Locality 180.

Discoidella simplex Croneis and Gale, 1939

Holotype: by original designation, UC 44426 described and illustrated by Croneis and Gale, 1939, p. 276, pl. 5, figs. 16-17. Figured by Sylvester-Bradley in Moore, 1961, p. Q408, fig. $330,3 a$.

Stratigraphic position: Upper Mississippian, Golconda Formation, Locality 152.

Remarks: Sohn, 1954, p. 8 , states that " $D$. simplex Croneis and Gale 1938, is not an ostracode." 
Dizygopleura trisinuata Van Pelt, 1933

Holotype: by original designation, UC 38606 described and illustrated by Van Pelt, 1933, pp. 328-329, pl. 39, fig. 61.

Referred specimen: the other specimen UC 38607 described and illustrated by Van Pelt, 1933, pp. 328-329, pl. 39, fig. 62.

Stratigraphic position: Middle Devonian, Bell Shale, Localities 124 (holotype) and 126 (referred specimen).

Remarks: UC 38606 and UC 38607 consist of single valves only.

Drepanella richardsoni (S. A. Miller)

See: Beyrichia richardsoni S. A. Miller, 1874

Ectodemites bicarinatus (Croneis and Thurman)

See: Amphissites bicarinatus Croneis and Thurman, 1939

Remarks: the name Ectodemites Cooper, 1941, is placed in the synonymy of Amphissites Girty, 1910, by Sohn in Moore, 1961, p. Q165.

Ectodemites costelliferus (Croneis and Bristol)

See: Amphissites costellifera Croneis and Bristol, 1939 Amphissites decipiens Croneis and Bristol, 1939

Remarks: the name Ectodemites Cooper, 1941, is placed in the synonymy of Amphissites Girty, 1910, by Sohn in Moore, 1961, p. Q165.

Ectodemites dattonensis (Harlton)

See: Amphissites dattonensis Harlton, 1927

Ectodemites geneae (Roth)

See: Amphissites pinguis (Ulrich and Bassler)

Ectodemites obesus (Croneis and Gale)

See: Amphissites obesus Croneis and Gale, 1939

Remarks: the name Ectodemites Cooper, 1941, is placed in the synonymy of Amphissites Girty, 1910, by Sohn in Moore, 1961, p. Q165.

Ellipsella calcar (Harlton)

See: Ellipsella distenta Kellett, 1935 


\section{Ellipsella distenta Kellett, 1935}

See: Jonesina distenta Kellett, 1933

Remarks: the name Ellipsella Coryell and Rogatz, 1932, is placed in the synonymy of Oliganisus Geis, 1932, by Sohn in Moore, 1961, p. Q182. The name Ellipsella distenta Kellett, 1933, is placed in the synonymy of Ellipsella calcar (Harlton) by Cooper, 1946, p. 109.

\section{Elpe irregularis (S. A. Miller)}

See: Cythere irregularis S. A. Miller, 1878

\section{Entomis rugatulus Van Pelt, 1933}

Holotype: by original designation, UC 38608 described and illustrated by Van Pelt, 1933, pp. 340-341, pl. 39, fig. 21.

Referred specimen: the other specimen UC 38609 described and illustrated by Van Pelt, 1933, pp. 340-341, pl. 39, fig. 22.

Stratigraphic position: Middle Devonian, Bell Shale, Localities 124 (holotype) and 126 (referred specimen).

Remarks: holotype consists of single valve. The name Entomis Jones, 1861, is placed in the synonymy of Entomozoe Pribyl, 1951, by Sylvester-Bradley in Moore, 1961, p. Q389.

\section{Entomozoe rugatulus (Van Pelt)}

See: Entomis rugatulus Van Pelt, 1933

\section{Euglyphella sigmoidalis (Jones)}

See: Octonaria percarinata Van Pelt, 1933

\section{Eurychilina bassleri Roy, 1941}

Holotype: by original designation, P 28881 described and illustrated by Roy, 1941, pp. 173-174, text-fig. 141.

Stratigraphic position: Upper Ordovician, Richmond, Locality 243. Remarks: P 28881 consists of a nearly perfect left valve in a piece of blue grey limestone of the dimensions $8 \times 5 \times 3 \mathrm{~mm}$.

\section{Eurychilina jerseyensis S. Weller, 1903}

Holotype: UC 10256 described and illustrated by Weller, 1903, pp. 210-211, pl. 13, fig. 17 (cited on pp. 42, 43).

Referred specimen: the other original specimen UC 10256 described by Weller, 1903, pp. 210-211. 
Stratigraphic position: Ordovician, Trenton Limestone, Locality 223.

Remarks: UC 10256 consists of two valves, each on a separate chip of dark limestone. The holotype is the larger specimen on the larger chip. Referred to Coelochilina jerseyensis (S. Weller) by Bassler and Kellett, 1934, p. 246).

Eurychilina oculifera S. Weller, 1903

Holotype: UC 10257 described and illustrated by Weller, 1903, p. 210, pl. 13, fig. 16 (cited on pp. 42, 43).

Referred specimen: the other original specimen UC 10257 described by Weller, 1903, p. 210.

Stratigraphic position: Ordovician, Trenton Limestone, Locality 223.

Remarks: UC 10257 consists of two complete valves, in black limestone. The holotype is marked by an orange diamond. Referred to Coelochilina oculifera (S. Weller) by Ulrich and Bassler, 1923a, p. 521; and by Bassler and Kellett, 1934, p. 246.

\section{Eurychilina sp.}

Referred specimen: P 28882 described and illustrated by Roy, 1941, p. 174, text-fig. 142.

Stratigraphic position: Upper Ordovician, Richmond, Locality 243. Remarks: The specimen is an external mold of a left valve in a $9 \times 9 \times 2 \mathrm{~mm}$. piece of grey-blue limestone.

Geisina bicornis (Croneis and Gale)

See: Perprimitia ? bicornis Croneis and Gale, 1939

Geisina elegans (Croneis and Gutke)

See: Perprimitia elegans Croneis and Gutke, 1939

Geisina funkhouseri (Croneis and Thurman)

See: Perprimitia funkhouseri Croneis and Thurman, 1939

Geisina matheri (Croneis and Bristol)

See: Perprimitia matheri Croneis and Bristol, 1939

Geisina robusta (Croneis and Gale)

See: Perprimitia robusta Croneis and Gale, 1939 


\section{Geisina spinosa (Croneis and Gale)}

See: Perprimitia spinosa Croneis and Gale, 1939

Geisina turrita (Croneis and Gutke)

See: Perprimitia turrita Croneis and Gutke, 1939

Glyptopleura adunca Croneis and Thurman, 1939

Holotype: by original designation, UC 44516A described and illustrated by Croneis and Thurman, 1939, pp. 317-318, pl. 8, fig. 3.

Referred specimen: UC $44516 \mathrm{~B}$ described by Croneis and Thurman, 1939, pp. 317-318.

Stratigraphic position: Upper Mississippian, Kinkaid Formation, Locality 144.

Glyptopleura alata Croneis and Funkhouser, 1939

Holotype: by original designation, UC 44465 described and illustrated by Croneis and Funkhouser, 1939, pp. 349-350, pl. 10, fig. 3 .

Stratigraphic position: Upper Mississippian, Clore Formation, Locality 187.

Remarks: UC 44465 consists of a single valve and a fragment.

Glyptopleura alternata Croneis and Funkhouser, 1939

Holotype: by original designation, UC 44466 described and illustrated by Croneis and Funkhouser, 1939, pp. 350-351, pl. 10, fig. 7 .

Stratigraphic position: Upper Mississippian, Clore Formation, Locality 187.

Glyptopleura bristoli Croneis and Gutke, 1939

Holotype: by original designation, UC 45167 described and illustrated by Croneis and Gutke, 1939, pp. 49-50, pl. 2, figs. 3-4.

Referred specimen: the other specimen UC 51724 described by Croneis and Gutke, 1939, pp. 49-50.

Stratigraphic position: Upper Mississippian, Renault Formation, Locality 184 (published) and 186 (on slides and in Museum catalogs).

Also see: Glyptopleura pergibba Croneis and Gutke, 1939 
Glyptopleura carrolli Croneis and Bristol, 1939

Holotype: by original designation, UC 45125 described and illustrated by Croneis and Bristol, 1939, pp. 86-87, pl. 4, fig. 20.

Stratigraphic position: Upper Mississippian, Menard Formation, Locality 169.

Remarks: holotype consists of single valve.

Glyptopleura complexa Croneis and Funkhouser, 1939

Holotype: by original designation, UC 44467 described and illustrated by Croneis and Funkhouser, 1939, pp. 351-352, pl. 10, fig. 2.

Referred specimens: the other three specimens UC 44484 described by Croneis and Funkhouser, 1939, pp. 351-352. UC 45126 and UC 51702 described by Croneis and Bristol, 1939, p. 87; UC 45126 illustrated by them pl. 4, fig. 25 .

Stratigraphic position: Upper Mississippian, Clore Formation, Locality 189 (UC 44467 and UC 44484); Menard Formation, Locality 160 (UC 45126 and UC 51702).

Remarks: UC 44467, UC 44484 and UC 45126 consist of single valves only.

Also see: Glyptopleura hamatilis Croneis and Bristol, 1939

Glyptopleura compta Croneis and Thurman, 1939

Holotype: by original designation, UC 44517A described and illustrated by Croneis and Thurman, 1939, pp. 318-319, pl. 8, fig. 4 .

Referred specimen: UC 44517B, two incomplete valves, described by Croneis and Thurman, 1939, pp. 318-319.

Stratigraphic position: Upper Mississippian, Kinkaid Formation, Locality 143.

Glyptopleura conflexacosta ta Croneis and Gale, 1939

Holotype: by original designation, UC 44429 described and illustrated by Croneis and Gale, 1939, pp. 278-279, pl. 6, fig. 7.

Referred specimens: UC 45127 and UC 51703 described by Croneis and Gale, 1939, pp. 87-88. UC 45127 illustrated by them, pl. 4, fig. 21.

Stratigraphic position: Upper Mississippian, Golconda Formation, Locality 152 (UC 44429); Menard Formation, Locality 160 (UC 45127 and UC 51703).

Remarks: UC 44429 and UC 45127 consist of single valves only. 
Glyptopleura ? curvata Croneis and Gale, 1939

Holotype: by original designation, UC 44433 described and illustrated by Croneis and Gale, 1939, pp. 281-282, pl. 6, figs. 15-16.

Stratigraphic position: Upper Mississippian, Golconda Formation, Locality 151.

Glyptopleura decacostata Croneis and Gale, 1939

Holotype: by original designation, UC 44428 described and illustrated by Croneis and Gale, 1939, pp. 277-278, pl. 6, fig. 5 . Cited and illustrated by Shimer and Shrock, 1944, p. 681, pl. 285, fig. 48.

Stratigraphic position: Upper Mississippian, Golconda Formation, Locality 151.

Remarks: UC 44428 consists of a single valve.

Glyptopleura elliptica Croneis and Gutke, 1939

Holotype: by original designation, UC 45168 described and illustrated by Croneis and Gutke, 1939, pp. 50-51, pl. 2, fig. 9.

Stratigraphic position: Upper Mississippian, Renault Formation, Locality 180.

Glyptopleura gibba Croneis and Gale, 1939

Holotype: by original designation, UC 44432 described and illustrated by Croneis and Gale, 1939, pp. 280-281, pl. 6, figs. 9-10.

Stratigraphic position: Upper Mississippian, Golconda Formation, Locality 153.

Glyptopleura hamatilis Croneis and Bristol, 1939

Holotype: by original designation, UC 45128 described and illustrated by Croneis and Bristol, 1939, pp. 88-89, pl. 4, fig. 22.

Stratigraphic position: Upper Mississippian, Menard Formation, Locality 160.

Remarks: UC 45128 consists of one valve. Referred by Cooper, 1941, p. 40, to Glyptopleura complexa Croneis and Bristol, 1939.

Glyptopleura harltoni Croneis and Bristol, 1939

Holotype: by original designation, UC 45129 described and illustrated by Croneis and Bristol, 1939, pp. 89-90, pl. 4, fig. 26.

Stratigraphic position: Upper Mississippian, Menard Formation, Locality 172. 
Remarks: UC 45129 consists of one valve.

Glyptopleura henbesti Croneis and Gutke, 1939

Holotype: by original designation, UC 45169 described and illustrated by Croneis and Gutke, 1939, pp. 51-52, pl. 2, figs. 7-8. Cited and illustrated by Shimer and Shrock, 1944, p. 681, pl. 285, figs. 49-50.

Referred specimen: the other specimen UC 51725 described by Croneis and Gutke, 1939, pp. 51-52.

Stratigraphic position: Upper Mississippian, Renault Formation, Locality 184 (published) and 186 (on slide and in Museum catalogs).

Also see: Glyptopleura hendricksi Croneis and Gutke, 1939

Glyptopleura hendricksi Croneis and Gutke, 1939

Holotype: by original designation, UC 45170 described and illustrated by Croneis and Gutke, 1939, pp. 52-53, pl. 2, figs. 5-6.

Stratigraphic position: Upper Mississippian, Renault Formation, Locality 180.

Remarks: referred by Cooper, 1941, pp. 40-41, to Glyptopleura henbesti Croneis and Gutke, 1939.

Glyptopleura in termedia Croneis and Gale, 1939

Holotype: by original designation, UC 44430 described and illustrated by Croneis and Gale, 1939, p. 279, pl. 6, fig. 6 .

Stratigraphic position: Upper Mississippian, Golconda Formation, Locality 151.

Remarks: UC 44430 consists of one valve. Croneis and Gale, 1939, in caption to fig. 6 , pl. 6 , spell it Glyptopleura intermidia. It is considered to be a spelling error.

Glyptopleura kayi Croneis and Bristol, 1939

Holotype: by original designation, UC 45130 described and illustrated by Croneis and Bristol, 1939, pp. 90-91, pl. 9, fig. 23.

Stratigraphic position: Upper Mississippian, Menard Formation, Locality 173.

Glyptopleura kellettae Croneis and Thurman, 1939

Holotype: by original designation, UC 44518A described and illustrated by Croneis and Thurman, 1939, pp. 319-320, pl. 8, fig. 8 . Cited by Cooper, 1941, p. 41. 
Referred specimen: UC 44518B, a valve, described by Croneis and Thurman, 1939, pp. 319-320.

Stratigraphic position: Upper Mississippian, Kinkaid Formation, Locality 144.

Glyptopleura pentacostata Croneis and Gale, 1939

Holotype: by original designation, UC 44431 described and illustrated by Croneis and Gale, 1939, pp. 279-280, pl. 6, fig. 8.

Stratigraphic position: Upper Mississippian, Golconda Formation, Locality 155.

Glyptopleura pergibba Croneis and Gutke, 1939

Holotype: by original designation, UC 45171 described and illustrated by Croneis and Gutke, 1939, pp. 53-54, pl. 2, figs. 1-2.

Stratigraphic position: Upper Mississippian, Renault Formation, Locality 184 (published) and 186 (on slide and in Museum catalogs).

Remarks: referred by Cooper, 1941, p. 40, to Glyptopleura bristoli Croneis and Gutke, 1939.

Glyptopleura pseudosulcata Croneis and Thurman, 1939

Holotype: by original designation, UC 44519A described and illustrated by Croneis and Thurman, 1939, pp. 320-321, pl. 8, fig. 7 .

Referred specimens: two other complete specimens on one slide, UC 44519B, described by Croneis and Thurman, 1939, pp. 320321.

Stratigraphic position: Upper Mississippian, Kinkaid Formation, Locality 145.

Glyptopleura reniformis Croneis and Thurman, 1939

Holotype: by original designation, UC 44520 described and illustrated by Croneis and Thurman, 1939, pp. 321-322, pl. 8, figs. 1-2.

Stratigraphic position: Upper Mississippian, Kinkaid Formation, Locality 145.

Glyptopleura resupinata Croneis and Bristol, 1939

Holotype: by original designation, UC 45131 described and illustrated by Croneis and Bristol, 1939, pp. 91-92, pl. 4, fig. 24. Cited and illustrated by Shimer and Shrock, 1944, p. 681, pl. 285, fig. 51 . 
Stratigraphic position: Upper Mississippian, Menard Formation, Locality 174.

Glyptopleura similis Croneis and Funkhouser, 1939

Holotype: by original designation, UC 44468 described and illustrated by Croneis and Funkhouser, 1939, pp. 352-353, pl. 10, fig. 4 .

Stratigraphic position: Upper Mississippian, Clore Formation, Locality 187.

Remarks: UC 44468 consists of a single valve.

Glyptopleura symmetrica Croneis and Funkhouser, 1939

Holotype: by original designation, UC 44469 described and illustrated by Croneis and Funkhouser, 1939, pp. 353-355, pl. 10, fig. 1.

Referred specimen: the other specimen, on slide UC 44469A, and the two specimens on slide UC 44469B, described by Croneis and Funkhouser, 1939, pp. 353-355.

Stratigraphic position: Upper Mississippian, Clore Formation, Locality 190.

Remarks: UC 44469 consists of two specimens. The specimen mounted at the top is the holotype.

Glyptopleura teretiformis Croneis and Thurman, 1939

Holotype: by original designation, UC 44521 described and illustrated by Croneis and Thurman, 1939, pp. 323-324, pl. 8, fig. 5 .

Stratigraphic position: Upper Mississippian, Kinkaid Formation, Locality 147.

Glyptopleura varians Croneis and Funkhouser, 1939

Holotype: by original designation, UC 44470 described and illustrated by Croneis and Funkhouser, 1939, pp. 355-356, pl. 10, figs. $5-6$.

Stratigraphic position: Upper Mississippian, Clore Formation, Locality 187.

Glyptopleura varicostata Croneis and Thurman, 1939

Holotype: by original designation, UC $44522 \mathrm{~A}$ described and illustrated by Croneis and Thurman, 1939, pp. 324-325, pl. 8, fig. 6 .

Referred specimen: UC 44522B, a single valve, described by Croneis and Thurman, 1939, pp. 324-325. 
Stratigraphic position: Upper Mississippian, Kinkaid Formation, Locality 142.

Glyptopleurina ? bulbosa Croneis and Gale, 1939

Holotype: by original designation, UC 44434 described and illustrated by Croneis and Gale, 1939, pp. 282-283, pl. 6, fig. 3. Cited and illustrated by Shimer and Shrock, 1944, p. 681, pl. 286, fig. 9 .

Stratigraphic position: Upper Mississippian, Golconda Formation, Locality 153.

Glyptopleurina complexa Croneis and Bristol, 1939

Holotype: by original designation, UC 45132 described and illustrated by Croneis and Bristol, 1939, pp. 92-93, pl. 4, fig. 16.

Stratigraphic position: Upper Mississippian, Menard Formation, Locality 175.

Glyptopleurina coryelli Croneis and Gutke, 1939

Holotype: by original designation, UC 45172 described and illustrated by Croneis and Gutke, 1939, pp. 54-55, pl. 2, figs. 21-22.

Referred specimen: the other specimen UC 51726 described by Croneis and Gutke, 1939, pp. 54-55.

Stratigraphic position: Upper Mississippian, Renault Formation, Locality 180.

Glyptopleurina insculpta (Croneis and Funkhouser)

See: Jonesina insculpta Croneis and Funkhouser, 1939

Glyptopleurina insignis (Croneis and Gale)

See: Idiomorpha insignis Croneis and Gale, 1939

Idiomorphina insignis (Croneis and Gale)

Glyptopleurina oehersi (Croneis and Bristol)

See: Idiomorphina oehersi Croneis and Bristol, 1939

Glyptopleurina ornata (Croneis and Gale)

See: Idiomorpha ornata Croneis and Gale, 1939

Idiomorphina ornata (Croneis and Gale)

Glyptopleurina simplex Croneis and Bristol, 1939

Holotype: by original designation, UC 45133 described and illustrated by Croneis and Bristol, 1939, p. 93, pl. 4, fig. 19. 
Stratigraphic position: Upper Mississippian, Menard Formation, Locality 160.

Glyptopleurina simulans Croneis and Gutke, 1939

Holotype: by original designation, UC 45173 described and illustrated by Croneis and Gutke, 1939, pp. 55-56, pl. 2, figs. 13-14.

Referred specimen: the other specimen UC 51727 described by Croneis and Gutke, 1939, pp. 55-56.

Stratigraphic position: Upper Mississippian, Renault Formation, Locality 180.

Glyptopleuroides girtyi Croneis and Gutke, 1939

Holotype: by original designation, UC 45174 described and illustrated by Croneis and Gutke, 1939, pp. 56-57, pl. 2, figs. 11-12. Stratigraphic position: Upper Mississippian, Renault Formation, Locality 180.

Glyptopleuroides insculptus Croneis and Gale, 1939

Holotype: by original designation, UC 44435 described and illustrated by Croneis and Gale, 1939, pp. 283-284, pl. 6, fig. 32. Cited and illustrated by Shimer and Shrock, 1944, p. 681, pl. 286, fig. 22.

Stratigraphic position: Upper Mississippian, Golconda Formation, Locality 151.

Glyptopleuroides perplexa Croneis and Gutke, 1939

Holotype: by original designation, UC 45175 described and illustrated by Croneis and Gutke, 1939, pp. 57-58, pl. 2, figs. 18-19.

Stratigraphic position: Upper Mississippian, Renault Formation, Locality 180.

Golcondella sulcata Croneis and Gale, 1939

Holotype: by original designation, UC 44408 described and illustrated by Croneis and Gale, 1939, pp. 262-263, pl. 5, fig. 30.

Referred specimens: the other two specimens on slide UC 44408 described by Croneis and Gale, 1939, pp. 262-263.

Stratigraphic position: Upper Mississippian, Golconda Formation, Locality 151.

Remarks: UC 44408 consists of three complete carapaces on one slide. Scott in Moore, 1961, p. Q413, states that: "Type speci- 
mens examined by Scott, who considered them to be molds of unknown ostracodes," he places the name Golcondella Croneis and Gale, 1939, in nomina dubia.

Graphiadactyllis catenulatus (Van Pelt)

See: Graphiodactylus catenulatus Van Pelt, 1933

\section{Graphiodactylus catenulatus Van Pelt, 1933}

Holotype: not designated; to be chosen from among UC $38610 \mathrm{~A}$ and UC 38610B described and illustrated by Van Pelt, 1933, pp. 333-334, pl. 39, figs. 31, 32 .

Stratigraphic position: Middle Devonian, Locality 124.

Remarks: the name Graphiodactylus Roth, 1929, is placed in the synonymy of Graphiadactyllis Roth, 1929, by Sohn and Stover in Moore, 1961, p. Q375, and by Pokorný, 1965, p. 233. Referred to Jenningsina catenulata (Van Pelt) by Coryell and Malkin, 1936, pp. 19-20; by Kesling and Weiss, 1953, p. 62; and by Sohn and Stover in Moore, 1961, p. Q375.

Halliella bellipuncta (Van Pelt)

See: Amphissites bellipunctus Van Pelt, 1933

Halliella jaynesi Roy, 1941

Holotype: by original designation, P 28880 described and illustrated by Roy, 1941, pp. 172-173, text-figs. 140a-d.

Stratigraphic position: Upper Ordovician, Richmond, Locality 243. Remarks: P 28880 is a free intact carapace.

Hamiltonella punctulifera (Hall)

See: Primitiopsis unicornis Van Pelt, 1933

Hastacypris bradyi Croneis and Gutke, 1939

Holotype: by original designation, UC 45180 described and illustrated by Croneis and Gutke, 1939, p. 61, pl. 2, figs. 16-17. Cited by Shaver in Moore, 1961, p. Q208.

Stratigraphic position: Upper Mississippian, Renault Formation, Locality 182 (published) and 185 (on slide and in Museum catalogs).

Haworthina bulleta (Harris and Lalicker)

Referred specimens: six specimens UC 51682 described by Kellett, 1935, p. 161. 
Stratigraphic position: Lower Permian, Neva Limestone, Locality 132 .

Healdia compressa Kellett, 1935

Referred specimens: UC 51683 described by Kellett, 1935, pp. 142143.

Stratigraphic position: Upper Pennsylvanian, Wabaunsee Group, Howard Formation, Locality 131.

Remarks: UC 51683 consists of 11 complete specimens and nine single valves. Kellett, 1936, p. 776, substituted the new name Healdia coryelli Kellett, 1936, for this species to rectify a homonymy. Referred by Cooper, 1946, p. 82, to Healdia coryelli Kellett, 1936.

Healdia coryelli Kellett, 1936

See: Healdia compressa Kellett, 1935

Healdia goniapleura Croneis and Bristol, 1939

Holotype: by original designation, UC 45139 described and illustrated by Croneis and Bristol, 1939, pp. 97-98, pl. 3, fig. 22.

Stratigraphic position: Upper Mississippian, Menard Formation, Locality 160.

Healdia ? menardensis Croneis and Bristol, 1939

Holotype: by original designation, UC 45140 described and illustrated by Croneis and Bristol, 1939, p. 98, pl. 3, fig. 28.

Stratigraphic position: Upper Mississippian, Menard Formation, Locality 160.

Remarks: referred by Cooper, 1941, p. 35, to Tetratylus menardensis (Croneis and Bristol).

Healdia opima Croneis and Gale, 1939

Holotype: lost

Referred specimen: UC 44443 described by Croneis and Gale, 1939, p. 290.

Stratigraphic position: Upper Mississippian, Golconda Formation, Locality 151.

Remarks: holotype was on same slide with referred specimen. Referred specimen should be designated holotype. 
Healdia ornata Morey, 1935

See: Healdia triangularis Croneis and Gale, 1939

Healdia parallela Kellett, 1935

Referred specimens: UC 51712 described by Kellett, 1935, p. 143.

Stratigraphic position: Lower Permian, Elmdale Formation, Locality 197.

Remarks: UC 51712 consists of two single valves only.

Healdia simplex Roundy, 1926

Referred specimens: UC 51710 described by Kellett, 1935, p. 142. Stratigraphic position: Middle Pennsylvanian, Stanton Limestone, Locality 192.

Remarks: UC 51710 consists of three complete specimens and one single valve.

Healdia triangularis Croneis and Gale, 1939

Holotype: by original designation, UC 44444 described and illustrated by Croneis and Gale, 1939, pp. 290-291, pl. 6, fig. 22. Cited and illustrated by Shimer and Shrock, 1944, p. 682, pl. 287, fig. 3.

Stratigraphic position: Upper Mississippian, Golconda Formation, Locality 151.

Remarks: referred by Cooper, 1941, p. 32, to Healdia ornata, Morey, 1935.

Healdia winfieldensis Upson, 1933

Referred specimens: UC 51711 described by Kellett, 1935, p. 143. Stratigraphic position: Permian, Chase Group, Wreford Formation, Locality 137.

Remarks: UC 51711 consists of four complete specimens and one single valve.

Hollina devoniana Van Pelt, 1933

Holotype: not designated; to be chosen from among UC 38611AUC $38611 \mathrm{D}$ described and illustrated by Van Pelt, 1933, pp. 327, 328, pl. 39, figs. 33-36.

Stratigraphic position: Middle Devonian, Bell Shale, Locality 124. Remarks: all specimens consist of single valves only. 
Hollinella burlingamensis Kellett, 1933

Referred specimen: UC 37821 described by Kellett, 1933, p. 72.

Stratigraphic position: Upper Pennsylvanian, Wabaunsee Group,

Burlingame Limestone, Locality 140.

Remarks: UC 37821 consists of single valve.

Hollinella crassamarginata Kellett, 1929

Referred specimens: UC 37822 described by Kellett, 1929, pp. 206207.

Stratigraphic position: Pennsylvanian, Wabaunsee Formation, Neva Member, Locality 200.

Remarks: UC 37822 consists of one complete specimen and three single valves. Referred by Bassler and Kellett, 1934, p. 332, to Hollinella crassimarginata Kellett, 1929.

Hollinella crassimarginata Kellett, 1929

See: Hollinella crassamarginata Kellett, 1929

- Hollinella emaciata (Ulrich and Bassler)

Referred specimens: UC 37820 described by Kellett, 1929, pp. 202203.

Stratigraphic position: Permian, Chase Formation, Fort Riley Limestone Member, Locality 208.

Remarks: UC 37820 consists of two specimens; one is complete, the other consists of a single valve only.

Hollinella gibbosa Kellett, 1929

Referred specimens: UC 37923 described by Kellett, 1929, pp. 207208.

Stratigraphic position: Pennsylvanian, Wabaunsee Formation, Americas? Member, Locality 205.

Remarks: UC 37923 consists of two single valves and one fragment.

Hollinella moreyi Croneis and Bristol, 1939

Holotype: by original designation, UC 45114 described and illustrated by Croneis and Bristol, 1939, pp. 77-78, pl. 4, fig. 18. Cited and illustrated by Shimer and Shrock, 1944, p. 669, pl. 282, fig. 4 .

Referred specimen: the other specimen UC 51704 described by Croneis and Bristol, 1939, pp. 77-78. 
Stratigraphic position: Upper Mississippian, Menard Formation, Locality 167.

Remarks: referred by Cooper, 1941, p. 46, to Hollinella radiata (Jones and Kirkby).

Hollinella nevensis Kellett, 1929

Referred specimens: five specimens UC 37924 described by Kellett, 1929, pp. 201-202.

Stratigraphic position: Permian, Wabaunsee Formation, Neva Member, Locality 206.

\section{Hollinella radiata (Jones and Kirkby)}

See: Hollinella moreyi Croneis and Bristol, 1939 Hollinella sp.

Hollinella shawneensis Kellett, 1929

See: Hollinella shawnensis Kellett, 1929

Hollinella shawnensis Kellett, 1929

Referred specimens: four specimens UC 37825 described by Kellett, 1929, p. 209.

Stratigraphic position: Pennsylvanian, Shawnee Formation, Howard Member, Locality 204.

Remarks: referred by Bassler and Kellett, 1934, p. 335, to Hollinella shawneensis Kellett, 1929.

\section{Hollinella ulrichi (Knight)}

Referred specimens: UC 37826 described by Kellett, 1933, pp. $70-$ 71.

Stratigraphic position: Lower Permian, Council Grove Group, Cottonwood Formation, Locality 134.

Remarks: UC 37826 consists of two free specimens on slide; one is a single valve and one is a fragment.

\section{Hollinella sp.}

Referred specimens: UC 44456 described and illustrated by Croneis and Funkhouser, 1939, p. 341, pl. 9, fig. 15.

Stratigraphic position: Upper Mississippian, Clore Formation, Locality 187. 
Remarks: UC 44456 consists of three specimens and three fragments on one slide. Referred by Cooper, 1941, p. 46, to Hollinella radiata (Jones and Kirkby).

\section{Hyphasmaphora textiligera Van Pelt, 1933}

Holotype: by original designation, UC 38612 described and illustrated by Van Pelt, 1933, p. 340, pl. 39, fig. 5 .

Referred specimen: the other specimen UC 38613 described and illustrated by Van Pelt, 1933, p. 340, pl. 39, figs. 3, 4, 6, 7.

Stratigraphic position: Middle Devonian, Bell Shale, Localities 124 (holotype) and 125 (referred specimen).

Remarks: both specimens consist of single valves only.

Idiomorpha insignis Croneis and Gale, 1939

Holotype: by original designation, UC 44435 described and illustrated by Croneis and Gale, 1939, pp. 284-285, pl. 6, fig. 4 .

Referred specimens: four other specimens on slide UC 44435 described by Croneis and Gale, 1939, pp. 284-285.

Stratigraphic position: Upper Mississippian, Golconda Formation, Locality 151.

Remarks: UC 44435 consists of five single valves on one slide. Croneis and Gale in Croneis, 1939, p. 28, proposed the new generic name Idiomorphina to rectify a homonymy. Referred by Cooper, 1941, p. 43, to Glyptopleurina insignis (Croneis and Gale). The name Idiomorpha Croneis and Gale, 1939, is placed in the synonymy of Glyptopleurina Coryell, 1928, by Scott, in Moore, 1961, p. Q184.

Idiomorpha ornata Croneis and Gale, 1939

Holotype: by original designation, UC 44437 described and illustrated by Croneis and Gale, 1939, pp. 285-286, pl. 6, figs. 1-2.

Stratigraphic position: Upper Mississippian, Golconda Formation, Locality 157.

Remarks: Croneis and Gale in Croneis, 1939, p. 28, proposed the new generic name Idiomorphina to rectify a homonymy. Referred by Cooper, 1941, p. 43, to Glyptopleurina ornata (Croneis and Gale). The name Idiomorpha Croneis and Gale, 1939, is placed in the synonymy of Glyptopleurina Coryell, 1928, by Scott in Moore, 1961, p. Q184. 
Idiomorphina insignis (Croneis and Gale)

See: Idiomorpha insignis Croneis and Gale, 1939

Remarks: the name Idiomorphina Croneis and Gale, 1939, is placed in the synonymy of Glyptopleurina Coryell, 1928, by Cooper, 1941, p. 42; and by Scott in Moore, 1961, p. Q184.

Idiomorphina oehersi Croneis and Bristol, 1939

Holotype: by original designation, UC 45134 described and illustrated by Croneis and Bristol, 1939, p. 94, pl. 4, fig. 17.

Referred specimen: the other specimen UC 51705 described by Croneis and Bristol, 1939, p. 94.

Stratigraphic position: Upper Mississippian, Menard Formation, Locality 160.

Remarks: the name Idiomorphina Croneis and Gale, 1939, is placed in the synonymy of Glyptopleurina Coryell, 1928, by Cooper, 1941, pp. 42-43, and by Scott in Moore, 1961, p. Q184.

Idiomorphina ornata (Croneis and Gale)

See: Idiomorpha ornata Croneis and Gale, 1939

Remarks: the name Idiomorphina Croneis and Gale, 1939, is placed in the synonymy of Glyptopleurina Coryell, 1928, by Cooper, 1941, pp. 42-43; and by Scott in Moore, 1961, p. Q184.

\section{Isochilina convexa Roy, 1941}

Holotype: by original designation, P 28877 described and illustrated by Roy, 1941, p. 170, text-fig. 137a.

Referred specimens: other specimens P 28877 described and illustrated by Roy, 1941, p. 170, text-figs. 137b and c.

Stratigraphic position: Upper Ordovician, Richmond, Locality 243.

Remarks: holotype is a right valve marked by an $\mathrm{x}$, with a fragment missing from the antero-ventral portion; it measures $5.1 \times$ $4 \mathrm{~mm}$. Referred specimens are both left valves, measuring $6.2 \times 4.9 \mathrm{~mm}$. and $5.3 \times 4.1 \mathrm{~mm}$. Undescribed complete right valve measuring $5.4 \times 4.2 \mathrm{~mm}$., is included with holotype and referred specimens.

Jenningsina catenulata (Van Pelt)

See: Graphiodactylus catenulatus Van Pelt, 1933 
Jonesina bolliaformis (Ulrich and Bassler)

Referred specimens: UC 37827 described by Kellett, 1933, pp. 7879 .

Stratigraphic position: Lower Permian, Council Grove Group, Cottonwood Formation, Locality 134.

Remarks: UC 37827 consists of 13 free specimens on slide; five are complete and eight are single valves. Referred by Cooper, 1946, p. 115, to Sansabella bolliaformis (Ulrich and Bassler).

Jonesina consimilis Croneis and Bristol, 1939

Holotype: by original designation, UC 45109 described and illustrated by Croneis and Bristol, 1939, pp. 74-75, pl. 30, figs. 29-30.

Stratigraphic position: Upper Mississippian, Menard Formation, Locality 164.

Remarks: referred by Cooper, 1941, p. 56, to Jonesina puncta Morey, 1935.

\section{Jonesina distenta Kellett, 1933}

Referred specimens: UC 37829 described by Kellett, 1933, pp. 8283.

Stratigraphic position: Upper Pennsylvanian, Wabaunsee Group, Howard Formation, Locality 131.

Remarks: UC 37829 consists of three free complete specimens on slide. Referred by Bassler and Kellett, 1934, p. 297, to Ellipsella distenta Kellett, 1933. Kellett, 1935, p. 162, states that "Jonesina distenta Kellett" should have read "Ellipsella distenta Kellett."

Jonesina ? dubia Croneis and Gale, 1939

Holotype: by original designation, UC 44412, described and illustrated by Croneis and Gale, 1939, pp. 265-266, pl. 5, fig. 29.

Stratigraphic position: Upper Mississippian, Golconda Formation, Locality 151.

Remarks: Croneis and Gale in Croneis, 1939, p. 28, substituted the new name Jonesina? skinneri for this species to rectify a homonymy. Referred by Cooper, 1941, p. 59 , to Sansabella bradfieldi (Coryell and Sohn).

Jonesina holli Croneis and Gutke, 1939

Holotype: by original designation, UC 45156 described and illustrated by Croneis and Gutke, 1939, p. 41, pl. 1, figs. 14-15. 
Referred specimen: the other specimen UC 51754 described by Croneis and Gutke, 1939, p. 41.

Stratigraphic position: Upper Mississippian, Renault Formation, Localities 182 (published) and 185 (on slides).

Remarks: referred by Cooper, 1941, p. 61, to Sansabella vinitaensis (Harlton).

Jonesina howardensis Kellett, 1933

Referred specimens: UC 37830 described by Kellett, 1933, pp. 8182.

Stratigraphic position: Upper Pennsylvanian, Wabaunsee Group, Howard Formation, Locality 131.

Remarks: UC 37830 consists of two free specimens on slide: one is complete and one is a fragment. Kellett, 1935, pp. 161-162, substituted the new name Jonesina upsoni for this species to rectify a homonymy.

Jonesina intermedia Croneis and Bristol, 1939

Holotype: by original designation, UC 45110 described and illustrated by Croneis and Bristol, 1939, p. 75, pl. 3, figs. 10-11.

Referred specimen: the other specimen UC 51706 described by Croneis and Bristol, 1939, p. 75.

Stratigraphic position: Upper Mississippian, Menard Formation, Locality 164.

Jonesina insculpta Croneis and Funkhouser, 1939

Holotype: by original designation, UC 44458 described and illustrated by Croneis and Funkhouser, 1939, pp. 342-343, pl. 10, figs. 21-22. Cited by Cooper, 1941, p. 43.

Referred specimens: other four specimens, UC 44480A and UC 44480B, described by Croneis and Funkhouser, 1939, pp. $342-$ 343.

Stratigraphic position: Upper Mississippian, Clore Formation, Locality 188.

Remarks: referred by Cooper, 1941, p. 43, to Glyptopleurina insculpta (Croneis and Funkhouser).

Jonesina lalickeri Croneis and Bristol, 1939

Holotype: by original designation, UC 45111 described and illustrated by Croneis and Bristol, 1939, pp. 75-76, pl. 3, fig. 9. 
Stratigraphic position: Upper Mississippian, Menard Formation, Locality 160.

Remarks: the holotype consists of one valve.

Jonesina persulcata Croneis and Gale, 1939

Holotype: by original designation, UC 44411 described and illustrated by Croneis and Gale, 1939, p. 265, pl. 6, fig. 21.

Referred specimen: the other specimen on slide UC 44411 described by Croneis and Gale, 1939, p. 265.

Stratigraphic position: Upper Mississippian, Golconda Formation, Locality 151.

Remarks: UC 44411 consists of two specimens, one is a complete carapace, the other a single valve.

Jonesina primitioides Harris and Lalicker, 1932

Referred specimens: UC 37828 described by Kellett, 1933, pp. 7981.

Stratigraphic position: Lower Permian, Neva Limestone, Locality 132.

Remarks: UC 37828 consists of five complete, free specimens on slide.

Jonesina puncta Morey, 1935

See: Jonesina consimilis Croneis and Bristol, 1939

Jonesina ? skinneri Croneis and Gale in Croneis, 1939

See: Jonesina? dubia Croneis and Gale, 1939

Jonesina spinosa Croneis and Funkhouser, 1939

Holotype: by original designation, UC 44459 described and illustrated by Croneis and Funkhouser, 1939, pp. 343-344, pl. 10, fig. 14 .

Referred specimen: UC 44459B, a valve, described by Croneis and Funkhouser, 1939, pp. 343-344.

Stratigraphic position: Upper Mississippian, Clore Formation, Locality 188, published, and Locality 187 on slide.

Remarks: UC 44459 consists of a single valve.

Jonesina (?) tumida Croneis and Thurman, 1939

Holotype: by original designation, UC 44505 described and illustrated by Croneis and Thurman, 1939, pp. 305-306, pl. 7, fig. 11. 
Stratigraphic position: Upper Mississippian, Kinkaid Formation, Locality 146.

Remarks: holotype consists of single valve. Referred by Cooper, 1941, p. 58, to Perprimitia funkhouseri Croneis and Thurman, 1939.

\section{Jonesina upsoni Kellett, 1935}

See: Jonesina howardensis Kellett, 1933

Jonesina wrighti Croneis and Gutke, 1939

Holotype: by original designation, UC 45157 described and illustrated by Croneis and Gutke, 1939, pp. 41-42, pl. 1, figs. 22-23.

Referred specimen: the other specimen UC 51755 described by Croneis and Gutke, 1939, pp. 41-42.

Stratigraphic position: Upper Mississippian, Renault Formation, Locality 180.

Remarks: referred by Cooper, 1941, p. 61, to Sansabella vinitaensis (Harlton).

\section{Kellettina robusta (Kellett)}

See: Ulrichia robusta Kellett, 1933

Kirkbya aequalis Croneis and Funkhouser, 1939

Holotype: by original designation, UC 44461 described and illustrated by Croneis and Funkhouser, 1939, pp. 345-346, pl. 10, figs. 17-19.

Referred specimen: the other specimen UC 44481 described by Croneis and Funkhouser, 1939, pp. 345-346.

Stratigraphic position: Upper Mississippian, Clore Formation, Locality 187.

Kirkbya bifrons Croneis and Thurman, 1939

Holotype: by original designation, UC 44506 described and illustrated by Croneis and Thurman, 1939, pp. 308-309, pl. 7, figs. $1-2$.

Stratigraphic position: Upper Mississippian, Kinkaid Formation, Locality 148.

Kirkbya canyonensis Harlton, 1929

Referred specimens: UC 37831 described by Kellett, 1933, p. 89. 
Stratigraphic position: Lower Permian, Elmdale Formation, Locality 138.

Remarks: UC 37831 consists of two free single valves on slide. Referred by Cooper, 1946, p. 105 to Kirkbya kellettae Harlton, 1929.

Kirkbya fossula Croneis and Bristol, 1939

Holotype: by original designation, UC 45116 described and illustrated by Croneis and Bristol, 1939, pp. 78-79, pl. 4, fig. 3.

Referred specimen: the other specimen, UC 51707 described by Croneis and Bristol, 1939, pp. 78-79.

Stratigraphic position: Upper Mississippian, Menard Formation, Locality 160.

Remarks: UC 45116 consists of one valve.

Kirkbya intermedia Croneis and Thurman, 1939

Holotype: by original designation, UC 44507 described and illustrated by Croneis and Thurman, 1939, pp. 309-310, pl. 7, fig. 3.

Stratigraphic position: Upper Mississippian, Kinkaid Formation, Locality 145.

Kirkbya kellettae Harlton, 1929

See: Kirkbya canyonensis Harlton, 1929

Kirkbya marginata Croneis and Funkhouser, 1939

Holotype: by original designation, UC 44462 described and illustrated by Croneis and Funkhouser, 1939, p. 346, pl. 10, fig. 20. Illustrated by Shimer and Shrock, 1944, pl. 282, fig. 21.

Referred specimen: the other specimen UC 44482 described by Croneis and Funkhouser, 1939, p. 346.

Stratigraphic position: Upper Mississippian, Clore Formation, Locality 189.

Remarks: UC 44482 consists of a single valve.

Kirkbya pergrandis Kellett, 1933

Referred specimen: UC 37832 described by Kellett, 1933, pp. 8586.

Stratigraphic position: Pennsylvanian, Shawnee Group, Deer Creek Formation, Ervine Creek Limestone Member, Locality 130. 
Kirkbya regularia Croneis and Gale, 1939

Holotype: by original designation, UC 44415 described and illustrated by Croneis and Gale, 1939, pp. 268-269, pl. 5, fig. 10. Illustrated by Shimer and Shrock, 1944, pl. 282, fig. 19.

Stratigraphic position: Upper Mississippian, Golconda Formation, Locality 151.

Remarks: UC 44415 consists of a single valve.

Kirkbya symmetrica Croneis and Thurman, 1939

Holotype: by original designation, UC 44508A described and illustrated by Croneis and Thurman, 1939, pp. 310-311, pl. 7, figs. 4-6.

Referred specimen: UC 44508B, a complete carapace, described by Croneis and Thurman, 1939, pp. 310-311.

Stratigraphic position: Upper Mississippian, Kinkaid Formation, Locality 148.

Kirkbya turrita Croneis and Gale, 1939

Holotype: by original designation, UC 44414 described and illustrated by Croneis and Gale, 1939, pp. 267-268, pl. 5, fig. 12.

Referred specimens: the other specimens on slide UC 44414 described by Croneis and Gale, 1939, pp. 267-268.

Stratigraphic position: Upper Mississippian, Golconda Formation, Locality 151.

Remarks: UC 44414 consists of three single valves.

Kirkbya wymani Kellett, 1933

Referred specimens: UC 37833 described by Kellett, 1933, pp. 9192.

Stratigraphic position: Lower Permian, Chase Group, Winfield Formation, Locality 136.

Remarks: UC 37833 consists of four specimens on slide; three are single valves and one is a fragment.

Kirkbyella bellipuncta (Van Pelt)

See: Amphissites bellipunctus Van Pelt, 1933

Kirkbyella gutkei Croneis and Bristol, 1939

Holotype: by original designation, UC 45123 described and illustrated by Croneis and Bristol, 1939, pp. 84-85, pl. 4, figs. 14-15. Illustrated by Pokorný, 1965, fig. 819 . 
Stratigraphic position: Upper Mississippian, Menard Formation, Locality 160.

Remarks: referred by Cooper, 1946, p. 106, to Kirkbyella cf. K. gutkei Croneis and Bristol, 1939.

Kirkbyella cf. K. gutkei Croneis and Bristol, 1939

See: Kirkbyella gutkei Croneis and Bristol, 1939

Kirkbyella quadrata Croneis and Gutke, 1939

Holotype: by original designation, UC 45165 described and illustrated by Croneis and Gutke, 1939, pp. 48-49, pl. 1, fig. 12.

Referred specimen: the other specimen UC 51722 described by Croneis and Gutke, 1939, pp. 48-49.

Stratigraphic position: Upper Mississippian, Renault Formation, Locality 182 (published) and 185 (on slides and in Museum catalogs).

\section{Knightina ampla Kellett, 1933}

Referred specimens: UC 37836 described by Kellett, 1933, p. 100. Stratigraphic position: Pennsylvanian, Shawnee Group, Lower (?) Deer Creek Formation, Locality 129.

Remarks: UC 37836 consists of two free single valves on slide.

Knightina bassleri Kellett, 1933

Referred specimens: UC 37837 described by Kellett, 1933, pp. 101102.

Stratigraphic position: Lower Permian, Chase Group, Wreford Formation, Locality 137.

Remarks: UC 37837 consists of three free specimens on slide; one is complete and two are single valves.

Knightina harltoni Kellett, 1933

Referred specimen: UC 37839 described by Kellett, 1933, pp. 99100.

Stratigraphic position: Middle Pennsylvanian, Stanton (?) Limestone, Locality 141.

Remarks: UC 37839 consists of a single valve.

Knightina incurva Kellett, 1933

Referred specimen: UC 37835 described by Kellett, 1933, p. 102. 
Stratigraphic position: Lower Permian, Chase Group, Winfield Formation, Locality 136.

Remarks: UC 37835 consists of single valve on slide.

Knightina minuta (Harris and Lalicker)

Referred specimens: UC 37840 described by Kellett, 1933, pp. 102 103.

Stratigraphic position: Lower Permian, Chase Group, Fort Riley Limestone, Locality 135.

Remarks: UC 37840 consists of two free specimens on slide; one is complete and one is a single valve.

Knightina neglecta Croneis and Gale, 1939

Holotype: by original designation, UC 44423 described and illustrated by Croneis and Gale, 1939, pp. 273-274, pl. 5, fig. 4.

Referred specimens: the other nine specimens on slide UC 44423 described by Croneis and Gale, 1939, pp. 273-274.

Stratigraphic position: Upper Mississippian, Golconda Formation, Locality 151.

Remarks: UC 44423 consists of ten specimens on slide; two specimens are complete, six are single valves, and two are fragments.

Knightina nodobliqua Croneis and Gale, 1939

Holotype: by original designation, UC 44424 described and illustrated by Croneis and Gale, 1939, pp. 274-275, pl. 5, fig. 1.

Stratigraphic position: Upper Mississippian, Golconda Formation, Locality 151.

Remarks: UC 44424 consists of a single valve. Referred by Cooper, 1941, p. 53, to Polytylites? nodobliquus (Croneis and Gale).

Knightina pinguoides Croneis and Gale, 1939

Holotype: by original designation, UC 44422 described and illustrated by Croneis and Gale, 1939, p. 273, pl. 5, fig. 15.

Referred specimen: the other specimen on slide UC 44422 described by Croneis and Gale, 1939, p. 273.

Stratigraphic position: Upper Mississippian, Golconda Formation, Locality 151.

Remarks: UC 44422 consists of two single valves on one slide. 
Knightina texana (Harlton)

Referred specimens: UC 37838 described by Kellett, 1933, pp. 100101.

Stratigraphic position: Lower Permian, Council Grove Group, Cottonwood Formation, Locality 134.

Remarks: UC 37838 consists of four single valves on slide.

Knoxina exu ta (Croneis and Gutke)

See: Chesterella exuta Croneis and Gutke, 1939

Knoxina fissurata (Croneis and Gutke)

See: Chesterella fissurata Croneis and Gutke, 1939

Knoxina indistincta Coryell and Rogatz, 1932

Referred specimens: five complete carapaces UC 48659 cited by Read, 1943, p. 479.

Stratigraphic position: Permian, Mabelle Limestone, Locality 209.

Knoxina inflata Croneis and Gale, 1939

Holotype: by original designation, UC 44413 described and illustrated by Croneis and Gale, 1939, pp. 266-267, pl. 6, figs. 17-18. Stratigraphic position: Upper Mississippian, Golconda Formation, Locality 157.

Knoxina rogatzi Croneis and Gutke, 1939

Holotype: by original designation, UC 45158 described and illustrated by Croneis and Gutke, 1939, pp. 42-43, pl. 2, figs. 26-27.

Referred specimen: the other specimen UC 51756 described by Croneis and Gutke, 1939, pp. 42-43.

Stratigraphic position: Upper Mississippian, Renault Formation, Locality 180.

Krausella cf. K. inaequalis Ulrich, 1894

Referred specimen: P 28884, described and illustrated by Roy, 1941, p. 175, text-figs. 144a and b.

Stratigraphic position: Upper Ordovician, Richmond, Locality 243. Remarks: the specimen is a complete free carapace.

Krausella rawsoni Roy, 1941

Holotype: by original designation, P 28883 described and illustrated by Roy, 1941, pp. 174-175, text-figs. 143a and b. 
Stratigraphic position: Upper Ordovician, Richmond, Locality 243. Remarks: P 28883 is a complete free carapace.

Lamarella thurmani Croneis and Funkhouser, 1939

Holotype: by original designation, UC 44451 described and illustrated by Croneis and Funkhouser, 1939, p. 336, pl. 9, figs. 1112.

Stratigraphic position: Upper Mississippian, Clore Formation, Locality 187.

Remarks: referred by Cooper, 1941, p. 60 , to Sansabella harrisi Croneis and Funkhouser, 1939. The name Lamarella Croneis and Funkhouser, 1939, is placed in the synonymy of Sansabella Roundy, 1926, by Sohn in Moore, 1961, p. Q187.

Leightonella torta Croneis and Gale, 1939

Holotype: by original designation, UC 44409 described and illustrated by Croneis and Gale, 1939, pp. 263-264, pl. 5, fig. 19.

Stratigraphic position: Upper Mississippian, Golconda Formation, Locality 153.

Remarks: UC 44409 consists of a single valve. Referred by Cooper, 1941, p. 54, to Deloia spinosa Croneis and Bristol, 1939. The name Leightonella Croneis and Gale, 1939, is placed in the synonymy of Beyrichiopsis Jones and Kirkby, 1886, by Sohn in Moore, 1961, p. Q185. Pokorný, 1965, p. 215, places Leightonella Croneis and Gale, 1939, in synonymy of Deloia Croneis and Thurman, 1939, and suggests that it may be congeneric with Beyrichiopsis Jones and Kirkby, 1886.

\section{Leperditella ornata S. Weller, 1903}

Holotype: not selected; should be selected from among UC 10255 . Referred specimens: other specimens UC 10255 described and illustrated by S. Weller, 1903, pp. 209-210, pl. 13, figs. 13-15.

Stratigraphic position: Ordovician, Trenton Limestone, Locality 223.

Remarks: UC 10255 consists of four complete carapaces.

Leperditia altoides S. Weller, 1903

Holotype: not selected, should be selected from among UC 10419. Referred specimens: UC 10419A, B, C, described and illustrated by S. Weller, 1903, pp. 252-253, pl. 23, fig. 1 (UC 10419A), and 
fig. 2 (UC 10419B); by Ulrich and Bassler, 1913, p. 513, pl. 97, figs. 8 and 9.

Stratigraphic position: Silurian, Decker Ferry Formation (Weller, 1903) and Rondout (Bassler and Kellett, 1934). Locality 215.

Remarks: UC 10419 consists of eight specimens on three chips of black limestone. UC 10419A (left valve) and UC 10419B (right valve) are illustrated by Weller, 1903 . UC 10419B also contains one unfigured specimen. UC $10419 \mathrm{C}$ contains five smaller specimens.

Leperditia byrnesi S. A. Miller, 1874

Holotype: UC 8823 described and illustrated by Miller, 1874, p. 123, text-fig. 10; cited and illustrated by Miller, 1889, p. 552, text-fig. 1020.

Referred specimens: the other ten original specimens UC 8823, described by Miller, 1874, p. 123.

Stratigraphic position: Ordovician, Cincinnatian, Locality 227.

Remarks: referred by Jones, 1890, p. 12 to Aechmina byrnesi (Miller). Referred to Dicranella byrnesi (Miller) by Ulrich, 1897, pp. 664-665; by Bassler, 1915, p. 415; and by Bassler and Kellett, 1934, p. 286.

Leperditia caecigena S. A. Miller, 1881

Holotype: UC 8883 described and illustrated by S. A. Miller, 1881, p. 262, pl. 6, figs. 5, 5a; by S. A. Miller, 1889, p. 552, text-fig. 1021.

Stratigraphic position: Ordovician, Cincinnatian, Locality 224.

Remarks: UC 8883 is a complete carapace.

Leperditia carbonaria (Hall)

Referred specimen: UC 14878 described and illustrated by S. Weller, 1916, p. 263, pl. 19, fig. 23.

Stratigraphic position: Mississippian, Ste. Genevieve Limestone, Locality 213.

Remarks: UC 14878 is a complete carapace.

Leperditia juvenis Croneis and Gale, 1939

Holotype: by original designation, UC 44400 described and illustrated by Croneis and Gale, 1939, pp. 255-256, pl. 5, fig. 20. 
Stratigraphic position: Upper Mississippian, Golconda Formation, Locality 152.

Leperditia cf. L. ulrichi Troedsson, 1928

Referred specimens: P 28876 described and illustrated by Roy, 1941, pp. 169-170, text-figs. 136a and b.

Stratigraphic position: Upper Ordovician, Richmond, Locality 243. Remarks: $\mathrm{P} 28876$ consists of two right valves on separate pieces of grey limestone. The larger chip of limestone measures $9 \times$ $7 \times 2.5 \mathrm{~mm}$.; the valve itself $6.5 \times 4 \mathrm{~mm}$. (fig. 136a); the smaller chip measures $5 \times 4 \mathrm{~mm}$., the valve itself $4.9 \times 3 \mathrm{~mm}$. (fig. 136b).

Macrocypris biconcava Croneis and Gutke, 1939

Holotype: by original designation, UC 45179 described and illustrated by Croneis and Gutke, 1939, p. 60, pl. 1, figs. 16-17.

Stratigraphic position: Upper Mississippian, Renault Formation, Locality 182 (published) and 185 (on slide and in Museum catalogs).

Macrocypris chapmani Croneis and Bristol, 1939

Holotype: by original designation, UC 45141 described and illustrated by Croneis and Bristol, 1939, p. 99, pl. 3, fig. 19.

Stratigraphic position: Upper Mississippian, Menard Formation, Locality 160.

Macrocypris garrisonensis Upson, 1933

Referred specimen: UC 51733 described by Kellett, 1935, p. 139. Stratigraphic position: Middle Pennsylvanian, Shawnee Group, Kanwaka Shale, Locality 202.

Mauryella golcondensis (Croneis and Gale)

See: Veracosella golcondensis Croneis and Gale, 1939

Michrocheilinella inflata Kellett, 1935

See: Microchilinella inflata Kellett, 1935

Microcheilinella pergracilis Croneis and Gale, 1939

Holotype: by original designation, UC 44447 described and illustrated by Croneis and Gale, 1939, p. 293, pl. 6, figs. 23-24.

Stratigraphic position: Upper Mississippian, Golconda Formation, Locality 154. 
Microchilinella inflata Kellett, 1935

Referred specimens: two specimens UC 51734 described by Kellett, 1935 , p. 140.

Stratigraphic position: Lower Permian, Elmdale Formation, Locality 138.

Remarks: Kellett, 1935, pp. 139-140, changed the spelling of Michrocheilinella to Microchilinella.

Microparaparchites inornatus Croneis and Bristol, 1939

Holotype: by original designation, UC 45101 described and illustrated by Croneis and Bristol, 1939, p. 69, pl. 3, fig. 31 .

Stratigraphic position: Upper Mississippian, Menard Formation, Locality 159.

Remarks: the name Microparaparchites Croneis and Gale, 1939, is placed in the synonymy of Pseudoparaparchites Kellett, 1933, by Scott in Moore, 1961, p. Q194.

Microparaparchites spinosus Croneis and Gale, 1939

Holotype: by original designation, UC 44402 described and illustrated by Croneis and Gale, 1939, pp. 256-257, pl. 6, figs. 30-31.

Referred specimens: the other specimen on slide UC 44402 described by Croneis and Gale, 1939, pp. 256-257. UC 45102 described and illustrated by Croneis and Bristol, 1939, pp. 6970, pl. 4, figs. 11, 12 .

Stratigraphic position: Upper Mississippian, Golconda Formation, Locality 153 (UC 44402); Menard Formation, Locality 160 (UC 45102).

Remarks: UC 44402 consists of two specimens, holotype is a complete carapace, referred specimen (UC 44402) consists of a single valve. The name Microparaparchites Croneis and Gale, 1939, is placed in the synonymy of Pseudoparaparchites Kellett, 1933, by Scott in Moore, 1961, p. Q194.

Milleratia cincinnatiensis (S. A. Miller)

See: Beyrichia cincinnatiensis S. A. Miller, 1875

Monoceratina furcula Croneis and Gale, 1939

Holotype: by original designation, UC 44406 described and illustrated by Croneis and Gale, 1939, p. 260, pl. 5, figs. 21-22.

Stratigraphic position: Upper Mississippian, Golconda Formation, Locality 153. 
Monoceratina lewisi Harris and Lalicker, 1932

Referred specimens: UC 51719 described by Kellett, 1935, pp. 158159.

Stratigraphic position: Permian, Chase Group, Fort Riley Limestone, Locality 135.

Remarks: UC 51719 consists of six single valves and one fragment.

Moorites minutus (Warthin)

Referred specimens: UC 37842 described by Kellett, 1933, pp. 104105.

Stratigraphic position: Upper Pennsylvanian, Wabaunsee Group, Howard Formation, Locality 131.

Remarks: UC 37842 consists of three free complete specimens on slide.

Moorites rhomboidalis (Croneis and Bristol)

See: Youngiella rhomboidalis Croneis and Bristol, 1939

Neokloedenella prima Croneis and Funkhouser, 1939

Holotype: lost

Referred specimens: the other specimens UC 44479 described by Croneis and Funkhouser, 1939, p. 342.

Stratigraphic position: Upper Mississippian, Clore Formation, Locality 188.

Remarks: UC 44479 consists of two complete specimens and one single valve. One of these specimens should be designated holotype. The name Neokloedenella Croneis and Funkhouser, 1939, is placed in the synonymy of Oliganisus Geis, 1932, by Sohn in Moore, 1961, p. Q182.

Neokloedenella secunda Croneis and Bristol, 1939

Holotype: by original designation, UC 45113 described and illustrated by Croneis and Bristol, 1939, p. 77, pl. 3, figs. 24, 25.

Stratigraphic position: Upper Mississippian, Menard Formation, Locality 166.

Remarks: the name Neokloedenella Croneis and Funkhouser, 1939, is placed in the synonymy of Oliganisus Geis, 1932, by Sohn in Moore, 1961, p. Q182. 
Neokloedenella subquadrata Croneis and Gutke, 1939

Holotype: by original designation, UC 45160 described and illustrated by Croneis and Gutke, 1939, p. 44, pl. 1, fig. 10.

Referred specimen: the other specimen UC 51758 described by Croneis and Gutke, 1939, p. 44.

Stratigraphic position: Upper Mississippian, Renault Formation, Locality 184 (published) and 186 (indicated on slides and $\mathrm{Mu}$ seum catalogs).

Remarks: the name Neokloedenella Croneis and Funkhouser, 1939, is placed in the synonymy of Oliganisus Geis, 1932, by Sohn in Moore, 1961, p. Q182.

\section{Octonaria crescentiformis Van Pelt, 1933}

Holotype: by original designation, UC 38614 described and illustrated by Van Pelt, 1933, pp. 334-335, pl. 39, fig. 58.

Referred specimens: other specimens, UC $38615 \mathrm{~A}$ and UC $38615 \mathrm{~B}$ described and illustrated by Van Pelt, 1933, pp. 334-335, pl. 39, figs. 55, 56, 57, 59 and 60 .

Stratigraphic position: Middle Devonian, Bell Shale, Localities 124 (holotype) and 127 (referred specimens).

\section{Octonaria percarinata Van Pelt, 1933}

Holotype: by original designation, UC 38618 described and illustrated by Van Pelt, 1933, pp. 335-336, pl. 39, fig. 52.

Referred specimens: other specimens UC 38319A and UC 38319B described and illustrated by Van Pelt, 1933, pp. 335-336, pl. 39, figs. 53, 54 .

Stratigraphic position: Middle Devonian, Bell Shale, Localities 124 (holotype) and 125 (referred specimens).

Remarks: UC 38319 and UC 38618 consist of single valves only. Referred by Bassler and Kellett, 1934, p. 419; by Warthin, 1934, pp. 220-221; by Kesling and Kilgore, 1952, p. 10, and by Kesling and Weiss, 1953, p. 58, to Euglyphella sigmoidalis (Jones).

\section{Octonaria quadricostata Van Pelt, 1933}

Holotype: by original designation, UC 38620 described and illustrated by Van Pelt, 1933, pp. 336-338, pl. 39, fig. 45.

Referred specimens: other specimens UC 38621A - UC 38321J described and illustrated by Van Pelt, 1933, pp. 336-338, pl. 39, figs. $41-44$ and $46-51$. 
Stratigraphic position: Middle Devonian, Bell Shale, Locality 124. Remarks: holotype consists of complete specimen; referred specimens consist of seven single valves, and of three complete carapaces.

Octonaria singularis Van Pelt, 1933

Holotype: by original designation, UC 38622 described and illustrated by Van Pelt, 1933, pp. 338-339, pl. 39, fig. 16.

Referred specimen: other specimen UC 38623 described by Van Pelt, 1933, pp. 338-339.

Stratigraphic position: Middle Devonian, Bell Shale, Locality 124. Remarks: holotype consists of a complete carapace; referred specimen consists of single valve only.

\section{Oliganisus distenta (Kellett)}

See: Ellipsella distenta Kellett, 1935

Oliganisus geisi Croneis and Gutke, 1939

Holotype: by original designation, UC 45159 described and illustrated by Croneis and Gutke, 1939, pp. 43-44, pl. 2, fig. 10.

Referred specimen: the other specimen UC 51757 described by Croneis and Gutke, 1939, pp. 43-44.

Stratigraphic position: Upper Mississippian, Renault Formation, Locality 180.

Oliganisus primus (Croneis and Funkhouser)

See: Neokloedenella prima Croneis and Funkhouser, 1939

Oliganisus secundus (Croneis and Bristol)

See: Neokloedenella secunda Croneis and Bristol, 1939

Oliganisus subquadratus (Croneis and Gutke)

See: Neokloedenella subquadrata Croneis and Gutke, 1939

Orthonotella faberi S. A. Miller, 1882

Holotype: lost, UC 8875 described and illustrated by Miller, 1882, p. 117, pl. 5, figs. 7 and $7 \mathrm{a}$ and $7 \mathrm{~b}$.

Stratigraphic position and locality: Ordovician, Cincinnatian, Maysville; Ohio River at Cincinnati, Ohio.

Remarks: Specimen is irrevocably lost, and is missing from vial. 
Paraparchites carbonarius (Hall)

See: Leperditia carbonaria (Hall)

Paraparchites cyclopeus (Girty)

See: Paraparchites robustus Croneis and Gutke, 1939

Paraparchites humerosus Ulrich and Bassler, 1906

Referred specimens: UC 37841 described by Kellett, 1933, pp. 6465.

Stratigraphic position: Lower Permian, Chase Group, Fort Riley Limestone, Locality 135.

Remarks: UC 37841 consists of four free specimens on slide; two are complete and two are single valves.

\section{Paraparchites inornatus (McCoy)}

Referred specimens: UC 44401 described and illustrated by Croneis and Gale, 1939, p. 256, pl. 6, fig. 33; UC 45151, UC 51750, and UC 51751 described by Croneis and Gutke, 1939, p. 37; UC 45151 illustrated by them on pl. 1, fig. 13; the specimen UC 45144 described by Croneis and Bristol, 1939, pp. 68-69.

Stratigraphic position: Upper Mississippian, UC 44401 from Golconda Formation, Locality 151; UC 45151, UC 51750, and UC 51751 from Renault Formation, Locality 180; UC 45144 from Menard Formation, Locality 158.

Remarks: UC 44401 consists of two complete carapaces.

Paraparchites kinkaidensis Croneis and Thurman, 1939

Holotype: by original designation, UC 44500 described and illustrated by Croneis and Thurman, 1939, p. 301, pl. 7, fig. 22.

Stratigraphic position: Upper Mississippian, Kinkaid Formation, Locality 144.

Paraparchites oviformis Coryell and Rogatz, 1932

Referred specimens: UC 48660 cited by Read, 1943, p. 479.

Stratigraphic position: Permian, Mabelle Limestone, Locality 209. Remarks: UC 48660 consists of five complete carapaces.

Paraparchites robustus Croneis and Gutke, 1939

Holotype: by original designation, UC 45152 described and illustrated by Croneis and Gutke, 1939, pp. 37-38, pl. 1, fig. 11. 
Referred specimen: the other specimen UC 51752 described by Croneis and Gutke, 1939, pp. 37-38.

Stratigraphic position: Upper Mississippian, Renault Formation, Locality 180.

Remarks: referred by Cooper, 1941, p. 61 to Paraparchites cyclopeus (Girty).

Perprimitia ? bicornis Croneis and Gale, 1939

Holotype: by original designation, UC 44405 described and illustrated by Croneis and Gale, 1939, p. 259, pl. 5, fig. 24.

Stratigraphic position: Upper Mississippian, Golconda Formation, Locality 152.

Remarks: the name Perprimitia Croneis and Gale, 1939, is placed in the synonymy of Geisina Johnson, 1936, by Sohn in Moore, 1961, p. Q182. Referred by Sohn, 1954, p. 19 to Coryellina bicornis (Croneis and Gale).

Perprimitia elegans Croneis and Gutke, 1939

Holotype: by original designation, UC 45153 described and illustrated by Croneis and Gutke, 1939, pp. 38-39, pl. 1, figs. 3-4. Cited by Cooper, 1941, p. 63.

Stratigraphic position: Upper Mississippian, Renault Formation, Locality 181.

Remarks: referred by Cooper, 1941, p. 63, and by Sohn, 1954, p. 19, to Coryellina elegans (Croneis and Gutke). The name Perprimitia Croneis and Gale, 1939, is placed in the synonymy of Geisina Johnson, 1936, by Sohn in Moore, 1961, p. Q182.

Perprimitia funkhouseri Croneis and Thurman, 1939

Holotype: by original designation, UC 44504 described and illustrated by Croneis and Thurman, 1939, pp. 304-305, pl. 7, figs. $18-19$.

Stratigraphic position: Upper Mississippian, Kinkaid Formation, Locality 144.

Remarks: see Jonesina (?) tumida Croneis and Thurman, 1939. The name Perprimitia Croneis and Gale, 1939, is placed in the synonymy of Geisina Johnson, 1936, by Sohn in Moore, 1961, p. Q182. 
Perprimitia matheri Croneis and Bristol, 1939

Holotype: by original designation, UC 45107 described and illustrated by Croneis and Bristol, 1939, pp. 72-73, pl. 3, fig. 16.

Stratigraphic position: Upper Mississippian, Menard Formation, Locality 162.

Remarks: UC 45107 consists of single valve only. The name Perprimitia Croneis and Gale, 1939, is placed in the synonymy of Geisina Johnson, 1936, by Sohn in Moore, 1961, p. Q182.

\section{Perprimitia robusta Croneis and Gale, 1939}

Holotype: by original designation, UC 44403 described and illustrated by Croneis and Gale, 1939, pp. 257-258, pl. 5, fig. 23. Illustrated by Shimer and Shrock, 1944, pl. 281, fig. 20. Described by Pokorný, 1965, p. 210.

Stratigraphic position: Upper Mississippian, Golconda Formation, Locality 151.

Remarks: see Perprimitia spinosa Croneis and Gale, 1939. The name Perprimitia Croneis and Gale, 1939, is placed in the synonymy of Geisina Johnson, 1936, by Sohn in Moore, 1961, p. Q182.

Perprimitia spinosa Croneis and Gale, 1939

Holotype: by original designation, UC 44404 described and illustrated by Croneis and Gale, 1939, pp. 258-259, pl. 5, fig. 28. Cited by Cooper, 1941, p. 58.

Stratigraphic position: Upper Mississippian, Golconda Formation, Locality 151.

Remarks: UC 44404 consists of a single valve. Referred by Cooper, 1941, p. 58, to Perprimitia robusta Croneis and Gutke, 1939. The name Perprimitia Croneis and Gale, 1939, is placed in the synonymy of Geisina Johnson, 1936, by Sohn in Moore, 1961, p. Q182.

Perprimitia turrita Croneis and Gutke, 1939

Holotype: by original designation, UC 45154 described and illustrated by Croneis and Gutke, 1939, pp. 39-40, pl. 1, figs. 24-25.

Stratigraphic position: Upper Mississippian, Renault Formation, Locality 182.

Remarks: the name Perprimitia Croneis and Gale, 1939, is placed in the synonymy of Geisina Johnson, 1936, by Sohn in Moore, 1961, p. Q182. 
Persansabella harrisi (Croneis and Funkhouser)

See: Sansabella harrisi Croneis and Funkhouser, 1939

Persansabella johnsoni (Croneis and Thurman)

See: Sansabella johnsoni Croneis and Thurman, 1939

Polytylites biforatus (Croneis and Thurman)

See: Amphissites biforatus Croneis and Thurman, 1939

Polytylites bradfieldi (Croneis and Funkhouser)

See: Amphissites bradfieldi (Croneis and Funkhouser)

Amphissites lineatus Croneis and Bristol, 1939

Amphissites rothi Croneis and Funkhouser, 1939

Polytylites concavus (Croneis and Bristol)

See: Amphissites concavus Croneis and Bristol, 1939

Polytylites elongatus (Croneis and Bristol)

See: Amphissites elongatus Croneis and Bristol, 1939

Polytylites fossilis (Croneis and Thurman)

See: Amphissites fossilis Croneis and Thurman, 1939

Poly tylites grovei (Croneis and Gutke)

See: Amphissites grovei Croneis and Gutke, 1939

Polytylites? nodobliquus (Croneis and Gale)

See: Knightina nodobliqua Croneis and Gale, 1939

Polytylites similis (Croneis and Gale)

See: Amphissites similis Croneis and Gale, 1939

Polytylites sublineatus (Croneis and Thurman)

See: Amphissites sublineatus Croneis and Thurman, 1939

Polytylites superus (Crones and Gale)

See: Amphissites superus Croneis and Gale, 1939

Polytylites trilobus (Croneis and Gale)

See: Amphissites trilobus Croneis and Gale, 1939 
Polytylites wilsoni (Croneis and Gutke)

See: Amphissites wilsoni Croneis and Gutke, 1939

\section{Ponderodictya punctulifera (Hall)}

See: Primitiopsis unicornis Van Pelt, 1933

Ponderodictya unicornis (Van Pelt)

See: Primitiopsis unicornis Van Pelt, 1933

Primitia byrnesi (S. A. Miller)

See: Leperditia byrnesi S. A. Miller, 1874

\section{Primitia cincinnatiensis (S. A. Miller)}

Referred specimens: P 28879 described and illustrated by Roy, 1941, pp. 172, 196, text-figs. 139a and b.

Stratigraphic position: Upper Ordovician, Richmond, Locality 243.

Remarks: P 28879 consists of two specimens, one right and one left valve.

Also see: Beyrichia cincinnatiensis S. A. Miller, 1875

Primitiopsis ? striatus Croneis and Funkhouser, 1939

Holotype: by original designation, UC 44455 described and illustrated by Croneis and Funkhouser, 1939, p. 340, pl. 10, fig. 13.

Stratigraphic position: Upper Mississippian, Clore Formation, Locality 188.

Remarks: UC 44455 consists of single valve. Referred by Cooper, 1941, pp. 44-45, and by Shimer and Shrock, 1944, p. 681, to Venula striata (Croneis and Funkhouser).

\section{Primitiopsis unicornis Van Pelt, 1933}

Holotype: not designated; to be chosen from among UC 38624AUC 38624D described and illustrated by Van Pelt, 1933, pp. 326-327, pl. 39, figs. 24 (UC 38624A); 25 (UC 38624D); 26 (UC 38624B); and fig. 27 (UC 38624C).

Stratigraphic position: Middle Devonian, Bell Shale, Locality 124. Remarks: all specimens consist of single valves. Referred by Bassler and Kellett, 1934, p. 466, to Primitiopsis ? unicornis Van Pelt, 1933; by Coryell and Malkin, 1936, p. 16, to Ponderodictya unicornis (Van Pelt); by Stewart, 1936, p. 756, to Hamiltonella punctulifera (Hall); by Warthin, 1934, pp. 222-223, to Cytherel- 
lina punctulifera (Hall); and by Kesling and Weiss, 1953, p. 66, to Ponderodictya punctulifera (Hall).

Primitiopsis ? unicornis Van Pelt 1933

See: Primitiopsis unicornis Van Pelt, 1933

Pseudoparaparchites (?) aclis Croneis and Thurman, 1939

Holotype: by original designation, UC 44501 described and illustrated by Croneis and Thurman, 1939, pp. 301-302, pl. 7, fig. 12.

Stratigraphic position: Upper Mississippian, Kinkaid Formation, Locality 149.

Remarks: holotype consists of single valve.

Pseudoparaparchites inornatus (Croneis and Bristol)

See: Microparaparchites inornatus Croneis and Bristol, 1939

Pseudoparaparchites spinosus (Croneis and Gale)

See: Microparaparchites spinosus Croneis and Gale, 1939

Pterocodella inconsueta Croneis and Gutke, 1939

Holotype: by original designation, UC 45155 described and illustrated by Croneis and Gutke, 1939, p. 40, pl. 1, figs. 7-8. Described by Cooper, 1941, p. 24.

Referred specimen: the other specimen UC 51753 described and illustrated by Croneis and Gutke, 1939, p. 40, pl. 1, fig. 9.

Stratigraphic position: Upper Mississippian, Renault Formation, Localities 183 (holotype) and 180 (referred specimen).

Remarks: Croneis and Gutke labelled the localities on their slides UC 45155 and UC 51753 as localities 180 and 183. This is reverse of the published localities. Referred by Cooper, 1941, p. 24, to Triceratina inconsueta (Croneis and Gutke). The name Pterocodella Croneis and Gale, 1939, is placed in the synonymy of Tetrasacculus Stewart, 1936, by Kesling in Moore, 1961, p. Q140.

Pterocodella mirablilis Croneis and Gale, 1939

Holotype: by original designation, UC 44407 described and illustrated by Croneis and Gale, 1939, pp. 261-262, pl. 5, figs. 25-27.

Referred specimens: two other specimens on slide UC 44407 described by Croneis and Gale, 1939, pp. 261-262.

Stratigraphic position: Upper Mississippian, Golconda Formation, Locality 151. 
Remarks: UC 44407 consists of a complete carapace (holotype) and two single valves (referred specimens). Referred by Cooper, 1941, pp. 63-64, to Tetrasacculus mirablilis (Croneis and Gale). The name Pterocodella Croneis and Gale, 1939, is placed in the synonymy of Tetrasacculus Stewart, 1936, by Kesling in Moore, 1961, p. Q140.

Ropolonellus papillatus Van Pelt, 1933

Holotype: by original designation, UC 38625 described and illustrated by Van Pelt, 1933, p. 339, pl. 39, fig. 29. Described by Pokorný, 1965, p. 232.

Referred specimen: the other specimen described and illustrated by Van Pelt, 1933, p. 339, pl. 39, fig. 30.

Stratigraphic position: Middle Devonian, Bell Shale, Locality 124.

Remarks: holotype consists of a complete carapace; referred specimen consists of a single valve only.

\section{Roundyella simplicissima (Knight)}

See: Amphissites (?) simplicissimus Knight, 1928

Sansabella bolliaformis (Ulrich and Bassler)

See: Jonesina bolliaformis (Ulrich and Bassler)

Sansabella bradfieldi (Coryell and Sohn)

See: Jonesina ? dubia Croneis and Gale, 1939

Sansabella laevis Croneis and Thurman, 1939

Sansabella johnsoni Croneis and Thurman in Croneis, 1939

Sansabella depressa (Croneis and Funkhouser)

See: Carboprimitia depressa Croneis and Funkhouser, 1939

Sansabella harrisi Croneis and Funkhouser, 1939

Holotype: by original designation, UC 44450 described and illustrated by Croneis and Funkhouser, 1939, pp. 334-335, pl. 9, figs. 7-8.

Referred specimens: the other three specimens UC 44476 described by Croneis and Funkhouser, 1939, pp. 334-335.

Stratigraphic position: Upper Mississippian, Clore Formation, Locality 188.

Remarks: referred by Sohn, 1940, pp. 154-159, to Persansabella harrisi (Croneis and Funkhouser). 
See: Sansabella thurmani (Croneis and Funkhouser)

Lamarella thurmani Croneis and Funkhouser, 1939

Sansabella johnsoni Croneis and Thurman in Croneis, 1939

Referred specimen: UC 45103 described and illustrated by Croneis and Bristol, 1939, p. 70, pl. 3, figs. 5-7.

Stratigraphic position: Upper Mississippian, Menard Formation, Locality 160.

Remarks: referred by Cooper, 1941, p. 59, to Sansabella bradfieldi (Coryell and Sohn). Referred by Sohn, 1940, pp. 154, 159, to Persansabella johnsoni (Croneis and Thurman).

See: Sansabella laevis Croneis and Thurman, 1939

Sansabella laevis Croneis and Thurman, 1939

Holotype: by original designation, UC 44502 described and illustrated by Croneis and Thurman, 1939, pp. 302-303, pl. 7, figs. 13-14.

Stratigraphic position: Upper Mississippian, Kinkaid Formation, Locality 143.

Remarks: Croneis and Thurman in Croneis, 1939, p. 29, substituted the new name Sansabella johnsoni for this species to rectify a homonymy. Referred by Cooper, 1941, p. 59, to Sansabella bradfieldi (Coryell and Sohn).

Sansabella rotunda (Croneis and Funkhouser)

See: Carboprimitia rotunda Croneis and Funkhouser, 1939

Sansabella rotunda var. tumida (Croneis and Funkhouser)

See: Carboprimitia rotunda var. tumida Croneis and Funkhouser, 1939

Sansabella simulans (Croneis and Thurman)

See: Carboprimitia simulans Croneis and Thurman, 1939

Sansabella spinosa (Croneis and Bristol)

See: Carboprimitia spinosa, Croneis and Bristol, 1939

Sansabella thurmani (Croneis and Funkhouser)

See: Lamarella thurmani Croneis and Funkhouser, 1939 
Remarks: the name Sansabella thurmani (Croneis and Funkhouser) is placed in the synonymy of Sansabella harrisi Croneis and Funkhouser, 1939, by Cooper, 1947a and 1947b, p. 91.

Sansabella vinitaensis (Harlton)

See: Jonesina holli Croneis and Gutke, 1939

Jonesina wrighti Croneis and Gutke, 1939

Sargentina crassimarginata (Croneis and Thurman)

See: Sulcella crassimarginata Croneis and Thurman, 1939

Seminolites sohni Croneis and Bristol, 1939

Holotype: by original designation, UC 45142 described and illustrated by Croneis and Bristol, 1939, pp. 99-100, pl. 3, figs. 26-27.

Stratigraphic position: Upper Mississippian, Menard Formation, Locality 160.

Silenites lenticularis (Knight)

Referred specimens: UC 51716 described by Kellett, 1935, p. 151.

- Stratigraphic position: Lower Permian, Elmdale Formation, Locality 198.

Remarks: UC 51716 consists of seven complete specimens, four single valves, and one fragment.

Sulcella crassimarginata Croneis and Thurman, 1939

Holotype: by original designation, UC 44526 described and illustrated by Croneis and Thurman, 1939, pp. 328-329, pl. 7, figs. $15-16$.

Stratigraphic position: Upper Mississippian, Kinkaid Formation, Locality 146.

Remarks: referred by Cooper, 1941, p. 39; $1947 \mathrm{a}$ and 1947 b, p. 91 , to Sargentina crassimarginata (Croneis and Thurman).

Tetrasacculus distinctus (Croneis and Gale)

See: Workmanella distincta Croneis and Gale, 1939

Tetrasacculus inconsuetus (Croneis and Gutke)

See: Pterocodella inconsueta Croneis and Gutke, 1939

Tetrasacculus mirablilis (Croneis and Gale)

See: Pterocodella mirablilis Croneis and Gale, 1939

Workmanella distincta Croneis and Gale, 1939 
Tetratylus menardensis (Croneis and Bristol)

See: Healdia ? menardensis Croneis and Bristol, 1939

Triceratina inconsueta (Croneis and Gutke)

See: Pterocodella inconsueta Croneis and Gutke, 1939

\section{Ulrichia robusta Kellett, 1933}

Referred specimens: UC 37834 described by Kellett, 1933, pp. 9293.

Stratigraphic position: Lower Permian, Chase Group, Wreford Formation, Locality 133.

Remarks: UC 37834 consists of five free single valves on slide. Referred by Cooper, 1946, p. 103, by Pokorný, 1965, p. 192, by Shimer and Shrock, 1944, p. 673, and by Swartz, 1936, pp. 577, 585 , to Kellettina robusta (Kellett).

Venula striata (Croneis and Funkhouser)

See: Primitiopsis ? striatus Croneis and Funkhouser, 1939

Verrucosella golcondensis Croneis and Gale, 1939

Holotype: by original designation, UC 44425 described and illustrated by Croneis and Gale, 1939, pp. 275-276, pl. 5, fig. 8.

Referred specimen: UC 45124 described and illustrated by Croneis and Bristol, 1939, p. 85, pl. 4, fig. 6.

Stratigraphic position: Upper Mississippian, Golconda Formation, Locality 152 (UC 44425) and Menard Formation, Locality 160 (UC 45124).

Remarks: referred by Cooper, 1941, p. 39, to Cornigella golcondensis (Croneis and Gale). The name Verrucosella Croneis and Gale, 1939, is placed in the synonymy of Mauryella Ulrich and Bassler, 1928, by Sohn, in Moore, 1961, pp. Q126-Q127.

Workmanella distincta Croneis and Gale, 1939

Holotype: by original designation, UC 44427 described and illustrated by Croneis and Gale, 1939, p. 277, pl. 5, fig. 11.

Referred specimen: the other specimen on slide UC 44427 described by Croneis and Gale, 1939, p. 277.

Stratigraphic position: Upper Mississippian, Golconda Formation, Locality 152. 
Remarks: UC 44427 consists of two single valves. Referred by Cooper, 1941, pp. 63-64, to Tetrasacculus mirablilis (Croneis and Gale). The name Workmanella Croneis and Gale, 1939, is placed in the synonymy of Tetrasacculus Stewart, 1938, by Kesling, in Moore, 1961, p. Q140.

Youngiella rhomboidalis Croneis and Bristol, 1939

Holotype: by original designation, UC 45143 described and illustrated by Croneis and Bristol, 1939, pp. 100-101, pl. 3, fig. 23.

Referred specimen: the other specimen UC 51708 described by Croneis and Bristol, 1939, pp. 100-101.

Stratigraphic position: Upper Mississippian, Menard Formation, Locality 160.

Remarks: referred by Cooper, 1941, p. 65, to Moorites rhomboidalis (Croneis and Bristol). 


\section{CATALOG OF CASTS}

Alu ta rotundata (Walcott)

See: Aristozoe rotundata Walcott, 1887

Alu ta troyensis (Ford)

See: Aristozoe troyensis (Ford)

Aparchites (?) robustus Matthew, 1898

Cast UC 13295 of holotype described and illustrated by Matthew, 1898, pp. 132-133, pl. 1, figs. 4a-c and by Ulrich and Bassler, 1931, pp. 22-23, pl. 1, fig. 1.

Stratigraphic position: Lower Cambrian, St. John Group, Locality 242.

Remarks: referred to Indiana? robusta (Matthew) by Matthew, 1902, p. 461 and by Bassler and Kellett, 1934, p. 160. Referred to Bradoria robusta (Matthew) by Ulrich and Bassler, 1931, p. 22; by Shimer and Shrock, 1944, p. 655; and by Sylvester-Bradley in Moore, 1961, p. Q102.

\section{Aristozoe rotundata Walcott, 1887}

Cast UC 26153 of USNM 17446 described and illustrated by Walcott, 1887, pp. 193-194, pl. 1, fig. 9; by Walcott, 1890, p. 627, pl. 80, fig. 13; by Ulrich and Bassler, 1931, p. 60, pl. 8, fig. 18. Stratigraphic position: Cambrian, Locality 216.

Remarks: referred to Aluta rotundata (Walcott) by Ulrich and Bassler, 1931, p. 60.

\section{Aristozoe troyensis (Ford)}

Cast UC 26152a of USNM 17447 described and illustrated by Walcott, 1887, p. 193, pl. 1, fig. 8; by Walcott, 1890, p. 628, pl. 80, fig. $2 \mathrm{a}$; and by Ulrich and Bassler, 1931, pp. 58-59, pl. 8, figs. $16-17$.

Stratigraphic position: Cambrian, Locality 217.

Remarks: UC 26152a is a left valve. Referred by Ulrich and Bassler, 1931, pp. 58-59 to Aluta troyensis (Ford). Associated with UC $26152 \mathrm{a}$ is a wax squeeze of a right valve, according to mu- 
seum catalog a "plastotype" from the same location. This specimen is not described or illustrated.

Beyrichona papilio Matthew, 1886

Cast UC 13280 of holotype described and illustrated by Matthew, 1886, pp. 65-66, pl. 6, figs. 20, 20a, 20b; by Matthew, 1895, p. 134, pl. 7, figs. 4a-c; and by Ulrich and Bassler, 1931, p. 43, pl. 7, fig. 5, and described by Miller, 1889, p. 535 .

Stratigraphic position: Cambrian, St. John Group, Locality 239.

Remarks: UC 13280 consists of an articulated right and left valve.

Beyrichona planata Matthew, 1895

Cast UC 13281 of holotype described and illustrated by Matthew, 1895, pp. 134-135, pl. 7, fig. 7; and by Ulrich and Bassler, 1931, pp. $45-46$, pl. 7 , fig. 1 .

Stratigraphic position: Cambrian, St. John Group, Locality 239.

Remarks: referred by Ulrich and Bassler, 1931, p. 45 to Beyrichona tinea planata (Matthew).

Beyrichona tinea Matthew, 1886

Cast UC 13282 of holotype described and illustrated by Matthew, 1886, p. 66, pl. 6, figs. 21, 21a, 21b; by Matthew, 1895, p. 134, pl. 7, figs. 6a-c; and by Ulrich and Bassler, 1931, pp. 43-44, pl. 7, fig. 4; and described by Matthew, 1894, p. 97.

Stratigraphic position: Cambrian, St. John Group, Locality 239.

Remarks: UC 13282 is a left valve. The description of anterior and posterior ends in Matthew, 1886 should be reversed (Matthew, 1894, p. 97, and Matthew, 1895, p. 134).

Beyrichona tinea planata (Matthew)

See: Beyrichona planata Matthew, 1895

Beyrichona tinea triangula (Matthew)

See: Beyrichona triangula Matthew, 1895

\section{Beyrichona trinagula Matthew, 1895}

Cast UC 13283 of holotype described and illustrated by Matthew, 1895, p. 135, pl. 7, fig. 5; and by Ulrich and Bassler, 1931, p. 44, pl. 7, figs. 8,9 .

Stratigraphic position: Cambrian, St. John Group, Locality 239. 
Remarks: Ulrich and Bassler, 1931, p. 44, contend that Matthew's 1895 , pl. 7, fig. 5 , is a composite of two specimens. Referred by Ulrich and Bassler, 1931, p. 44, to Beyrichona tinea triangula (Matthew).

\section{Bradoria cambrica (Matthew)}

See: Schmidtella cambrica Matthew, 1895

\section{Bradoria concinna (Matthew)}

See: Schmidtella? pervetus mut. concinna Matthew, 1902

\section{Bradoria? ornata Matthew, 1902}

Cast UC 13292 of holotype described and illustrated by Matthew, 1902, pp. 456-457, pl. 2, figs. 4a-c; by Matthew, 1903, pp. 166167, pl. 13, figs. 4a-c; and by Ulrich and Bassler, 1931, p. 30, pl. 1, fig. 24.

Stratigraphic position: Lower Cambrian, Lower Etcheminian, Locality 241.

Remarks: Ulrich and Bassler, 1931, p. 30, state that "the single example is too poor to be definitely placed ... the name should be dropped."

\section{Bradoria perspicator (Matthew)}

See: Bradorona observator Matthew, 1902

Bradorona perspicator Matthew, 1902

\section{Bradoria robusta (Matthew)}

See: A parchites? robustus (Matthew), 1898

\section{Bradoria spectator (Matthew)}

See: Bradorona spectator Matthew, 1902

\section{Bradorona observator Matthew, 1902}

Cast UC 13289 of specimen described and illustrated by Matthew, 1902 , pp. 448-449, pl. 1, figs. 15a-c; by Matthew, 1903, p. 160, pl. 12, figs. 15a-c; and by Ulrich and Bassler, 1931, pp. 24-25, pl. 1, fig. 7 .

Stratigraphic position: Lower Cambrian, Lower Etcheminian. Locality 240.

Remarks: UC 13289 is a wax squeeze of a left valve. Referred to Bradoria perspicator (Matthew) by Ulrich and Bassler, 1931, pp. 24-25. 
Bradorona perspicator Matthew, 1902

Cast UC 13290 of specimen described and illustrated by Matthew, 1902 , pp. 444-445, pl. 1, figs. 8a-d; by Matthew, 1903, pp. 156 157, pl. 12, figs. 8a-d; and by Ulrich and Bassler, 1931, pp. 2425, pl. 1, fig. 6, pl. 3, fig. 12(1).

Stratigraphic position: Lower Cambrian, Lower Etcheminian. Locality 232.

Remarks: UC 13290 is a wax squeeze of a left valve. Referred to Bradoria perspicator (Matthew) by Ulrich and Bassler, 1931, pp. 25-26.

\section{Bradorona spectator Matthew, 1902}

Cast UC 13291 of original specimen described and illustrated by Matthew, 1902, p. 447, pl. 1, figs. 12a-c; by Matthew, 1903, pp. 158-159, pl. 12, figs. 12a-c; and by Ulrich and Bassler, 1931, pp. 25-26, pl. 1, fig. 19.

Stratigraphic position: Lower Cambrian, Lower Etcheminian, Locality 240.

Remarks: UC 13291 is a wax squeeze of a left valve. Referred to Bradoria perspicator (Matthew) by Ulrich and Bassler, 1931, pp. 25-26.

Cypridina subovata Ulrich and Bassler, 1906

Casts UC 29762 of USNM 35626 described and illustrated by Ulrich and Bassler, 1906, pp. 162-163, pl. 11, figs. 23-26; and illustrated by Grabau and Shimer, 1910, text-figs. 1667x and y.

Stratigraphic position: Pennsylvanian, Lawrence Shale, Locality 212.

Remarks: UC 29762 consists of two wax squeezes taken from the right and left valves of USNM 35626.

Entomis waldronensis Ulrich, 1891

Cast UC 29632 of holotype USNM 41566, described and illustrated by Ulrich, 1891, p. 183, pl. 12, figs. $3 \mathrm{a}$ and $3 \mathrm{~b}$; and by Grabau and Shimer, 1910, p. 363, figs. $1668 \mathrm{~m}$ and $n$.

Stratigraphic position: Silurian, Niagaran, Locality 214.

Remarks: UC 29632 is a wax squeeze of a right valve USNM 41566.

\section{Hipponicharion cavatum Matthew, 1894}

Cast UC 13286 of specimen described and illustrated by Matthew, 1894, p. 99, pl. 17, figs. 3a and b; by Matthew, 1895, p. 133, 
pl. 7, figs. 2a and b; and by Ulrich and Bassler, 1931, p. 63, pl. 7, fig. 32 .

Stratigraphic position: Cambrian, St. John Group, Locality 239.

Remarks: Matthew's 1894 and 1895 figures appear identical but specimen is equivocally described as a right valve in 1894 and as a left valve in 1895 .

Hipponicharion eos Matthew, 1886

Cast UC 13285 of specimen described and illustrated by Matthew, 1886, pp. 64-65, pl. 6, figs. 19, 19a and b; by Matthew, 1895, p. 132, pl. 7, figs. 1a-c; by Ulrich and Bassler, 1931, pp. 6263, pl. 7, fig. 31; cited and illustrated by Sylvester-Bradley, in Moore 1961, p. Q102, text-fig. 39, 1 a.

Stratigraphic position: Cambrian, St. John Group, Locality 239.

Remarks: UC 13285 is a wax cast of a right valve only.

Hipponicharion minus Matthew, 1894

Cast UC 13284 of specimen described and illustrated by Matthew, 1894, p. 99, pl. 17, figs. 4a and b; by Matthew, 1895, p. 133, pl. 7, figs. $3 \mathrm{a}$ and b; and by Ulrich and Bassler, 1931, p. 63, pl. 7, fig. 30 .

Stratigraphic position: Cambrian, St. John Group, Locality 239.

Indiana dermatoides (Walcott)

See: Leperditia dermatoides Walcott, 1887

Indiana fusiformis (Matthew)

See: Primitia? fusiformis Matthew, 1895

Indiana pyriformis (Matthew)

See: Primitia pyriformis Matthew, 1898

Indiana? robusta (Matthew)

See: Aparchites? robustus Matthew, 1898

Isochilina amiana Ulrich, 1891

Cast UC 29467 of specimens described and illustrated by Ulrich, 1891, p. 180, pl. 11, figs. 12a-c; and by Swain, 1957, pp. 551-552, pl. 60 , fig. $3 \mathrm{a}$ and $\mathrm{b}$.

Stratigraphic position: Ordovician (Chazy), Beekmantown. Locality 237. 
Remarks: UC 29467 is a wax squeeze of the holotype and 16 other valves. Referred to Isochilina gregaria (Whitfield) by Bassler, 1915, p. 673; by Bassler and Kellett, 1934, p. 339; and by Swain 1957, pp. 551-552.

Isochilina amiana var. insignis Ulrich, 1891

Cast UC 29468 of holotype described and illustrated by Ulrich, 1891, p. 181, pl. 11, fig. 13; and described by Swain, 1957, p. 557.

Stratigraphic position: Ordovician (Chazy), Beekmantown, Locality 237.

Remarks: referred to Isochilina cristata (Whitfield) by Bassler, 1915, p. 672; by Bassler and Kellett, 1934, p. 337; and by Swain, 1957, p. 557.

Isochilina ampla Ulrich, 1891

Cast UC 29547 of USNM 41291 described and illustrated by Ulrich, 1891, p. 179, pl. 11, fig. 8d; by Swain, 1957, pp. 554-555, pl. 60, fig. 9a, text-fig. 9a; and cited by Scott in Moore, 1961, p. Q109.

Stratigraphic position: Ordovician, Trenton Group, Catheys Limestone, Dove member, Locality 238.

Remarks: UC 29547 is a wax squeeze of an internal mold of a right valve.

Isochilina cristata (Whitfield)

See: Isochilina amiana var. insignis Ulrich, 1891

Isochilina gregaria (Whitfield)

See: Isochilina amiana Ulrich, 1891

Isochilina subnodosa Ulrich, 1891

Cast UC 29545 of holotype USNM 41294 described and illustrated by Ulrich, 1891, pp. 177-178, pl. 11, figs. 7a-c; by Grabau and Shimer, 1910, p. 342, text-figs. $1656 \mathrm{i}-\mathrm{k}$; and by Swain, 1957, p. 554 , pl. 60 , fig. 8 .

Stratigraphic position: Ordovician, Trenton Group, Locality 236. Remarks: UC 29545 is a wax squeeze of a left valve.

Jonesella digitata Ulrich, 1890

Cast UC 29610 of holotype USNM 41358 described and illustrated by Ulrich, 1890, pp. 122-123, pl. 7, figs. 10a-c. 
Stratigraphic position: Ordovician, Cincinnatian (Arnheim), Locality 222.

Remarks: UC 29610 is a right valve. Referred to Jonesella? (? Kloedenella) digitata Ulrich, 1890 by Bassler and Kellett, 1934, p. 343.

Jonesella? (?Kloedenella) digitata Ulrich, 1890

See: Jonesella digitata Ulrich, 1890

Leperditella sulcata var. ventricornis (Ulrich)

See: Leperditia sulcata var. ventricornis Ulrich, 1892

Leperditia appressa Ulrich, 1891

Cast UC 29542 of specimen described and illustrated by Ulrich, 1891, p. 176, pl. 11, figs. 5a-c.

Stratigraphic position: Ordovician, Trenton Limestone, Locality 225.

Remarks: UC 29542 is a cast of one of the two original specimens of Ulrich, 1891.

Leperditia? argenta Walcott, 1886

Cast UC 26150 of specimen described and illustrated by Walcott, 1886, pp. 146-147, pl. 8, fig. 5.

Stratigraphic position: Middle Cambrian, Locality 220.

Remarks: referred by Resser, 1938, p. 25 to Tuzoia argenta (Walcott).

Leperditia bivia White, 1874

Cast UC 29613 of specimen described by White, 1874, p. 11; and described and illustrated by White, 1877, pp. 58-59, pl. 3, figs. $2 a-d(?)$.

Stratigraphic position: Ordovician, Upper Pogonip, Locality 228.

Remarks: UC 29613 is a wax squeeze of USNM 17411 but it is impossible to determine whether UC 29613 is the right valve (White, 1877, pl. 3, figs. 7b and d) or the left valve (White, 1877, pl. 2, figs. 7a and c). Stated by Jones, 1884, pp. 346-347 to be closely related to Leperditia canadensis var. labrosa Jones, 1858.

Leperditia dermatoides Walcott, 1887

Cast UC 26151 of the holotype USNM 17474 described and illustrated by Walcott, 1887, pp. 192-193, pl. 1, figs. 13 and 13a; 
by Walcott, 1890, pp. 626-627, pl. 80, figs. 1 and 1a; and by Ulrich and Bassler, 1931, p. 75, pl. 9, figs. 16, 16(1) and 17.

Stratigraphic position: Cambrian, Limestone interbedded in "shaly Taconic slate," Locality 218.

Remarks: referred to Indiana dermatoides (Walcott) by Ulrich and Bassler, 1931, p. 75.

Leperditia sulcata var. ventricornis Ulrich, 1892

Cast UC 29507 of holotype USNM 41314 described and illustrated by Ulrich, 1892, pp. 266-267, 270, pl. 9, figs. 22-23; cited and illustrated by Ulrich, 1897 , p. 636 , text-fig. $46 \mathrm{k}$.

Stratigraphic position: Ordovician (Black River), Lowville Limestone, Locality 231.

Remarks: It is not possible to discern the retrorsely directed ventral prominence in UC 29507. Ulrich, 1892, p. 270, indicates that the specimen is a right valve but the same illustration Ulrich, 1897, text-fig. 46k is described as a left valve. Referred by Ulrich, 1897, p. 636; Bassler, 1915, p. 697; and Bassler and Kellett, 1934, p. 375 to Leperditella sulcata var. ventricornis (Ulrich).

\section{Leperditia tumidula Ulrich, 1891}

Cast UC 29539 of holotype USNM 41284 described and illustrated by Ulrich, 1891, pp. 175-176, pl. 11, figs. 4a-c.

Stratigraphic position: Ordovician, Trenton, Locality 229.

\section{Mononotella fusiformis (Matthew)}

See: Primitia? fusiformis Matthew, 1895

\section{Nothozoe? vermontana Whitfield, 1884}

Cast UC 26154 of specimen described and illustrated by Walcott, 1890 , p. 628 , pl. 80 , fig. 4 .

Stratigraphic position: Lower Cambrian, Locality 219.

Remarks: UC 26154 is a poor wax impression. Moore, 1961, pp. Q413-414, places Nothozoe in nomina dubia, citing excessive size but suggesting possibility of its being a leperditiid.

\section{Primitia? fusiformis Matthew, 1895}

Cast UC 13293 of holotype described and illustrated by Matthew, 1895, p. 137, pl. 8, figs. 3a and b; and by Ulrich and Bassler, 1931, pp. 92-93, pl. 8, fig. 22. 
Stratigraphic position: Cambrian, St. John Group, Locality 239.

Remarks: Ulrich and Bassler, 1931, pp. 92-93, point out that the holotype is a left valve and the description by Matthew, 1895, should be reversed. Referred to Indiana fusiformis (Matthew) by Matthew, 1902, pp. 460-461; referred to Mononotella fusiformis (Matthew) by Ulrich and Bassler, 1931, pp. 92-93; by Bassler and Kellett, 1934, p. 444; and by Sylvester-Bradley in Moore, 1961, p. Q103. UC catalog gives locality 242; this undoubtedly is an error.

\section{Primitia pyriformis Matthew, 1898}

Cast UC 13294 of holotype described and illustrated by Matthew, 1898, p. 132, pl. 1, figs. 3a-c; and by Ulrich and Bassler, 1931, pp. $72-73$, pl. 9, fig. 11 .

Stratigraphic position: Cambrian, St. John Group, Locality 242.

Remarks: referred to Indiana pyriformis (Matthew) by Matthew, 1902, pp. 460-461; by Ulrich and Bassler, 1931, pp. 72-73; by Bassler and Kellett, 1934, p. 453; and by Sylvester-Bradley in Moore 1961, p. Q103.

\section{Schmidtella cambrica Matthew, 1895}

Cast UC 13287 of holotype described and illustrated by Matthew, 1895, p. 137, pl. 7, figs. 10a and b; and by Ulrich and Bassler, 1931, p. 28, pl. 1, fig. 10 .

Stratigraphic position: Cambrian, St. John Group, Locality 239.

Remarks: referred to Bradoria cambrica (Matthew) by Ulrich and Bassler, 1931, p. 28 and by Bassler and Kellett, 1934, p. 471.

Schmid tella? pervetus mut. concinna Matthew, 1902

Cast UC 13288 of holotype described by Matthew, 1902, pp. 464465; by Matthew, 1903, p. 173; described and illustrated by Ulrich and Bassler, 1931, p. 28, pl. 3, fig. 9.

Stratigraphic position: Lower Cambrian, Lower Etcheminian, Locality 240.

Remarks: referred to Bradoria cuncinna (Matthew) by Ulrich and Bassler, 1931, p. 28.

Tuzoia argenta (Walcott)

See: Leperditia? argenta Walcott, 1886 


\section{GATALOG OF LOGALITIES}

Locality 124.-Van Pelt collection. Shale pocket in the Dundee Limestone in Calcite quarry, Rogers City, Presque Isle County, Michigan.

Locality 125.-Van Pelt collection. Quarry in Alpena, Michigan.

Locality 126.-Van Pelt collection. Road cut, two miles south of town of Bell, Michigan.

Locality 127.-Van Pelt collection. Rockport quarry, two miles south of Rogers City, Michigan.

Locality 128.-Van Pelt collection. Rockport quarry, two miles south of Rogers City, and Rogers City, Michigan.

Locality 129.-Kellett's (1933) locality no. 1. Decomposed limestone from outcrop on Highway $73 \mathrm{~W}$, one-quarter mile west of Oskaloosa, Jefferson County, Kansas.

Locality 130.-Kellett's (1933) locality no. 3. Quarry at Oskaloosa, Jefferson County, Kansas.

Locality 131.-Kellett's (1933) locality no. 25. Brick plant cut in field, north of Gage Park, Topeka, Shawnee County, Kansas.

Locality 132.-Kellett's (1933) locality no. 42. South of the Kansas State Agricultural College and near cemetery, Manhattan, Riley County, Kansas.

Locality 133.--Kellett's (1933) locality no. 43. Outcrops on hill along Highway 40 opposite the soldiers' monument, Camp Funston, Geary County, Kansas.

Locality 134.-Kellett's (1933) locality no. 44. Limestone on Highway 40 at Ogden, Riley County, Kansas.

Locality 135.-Kellett's (1933) locality no. 45. On Highway 40 opposite cemetery, Fort Riley, Geary County, Kansas. 
Locality 136.--Kellett's (1933) locality no. 56. Outcrop on hillside at junction of country road and highway, eight miles southeast of Lincolnville, Marion County, on route to Elmdale, Kansas. There are two limestones, separated by a yellow shale; the upper of the limestones is concretionary.

Locality 137.-Kellett's (1933) locality no. 57. Low outcrop by north-south road, north of District No. 17 School, Chase County, Kansas. This locality is between Lincolnville and Elmdale, and only a few miles from the latter. There are three limestones, the lower one being very cherty and overlain by yellow shale.

Locality 138.-Kellett's (1933) locality no. 64. Very carbonaceous fossiliferous shale on top of the massive buff limestone. Thick section exposed near the Cottonwood River bridge east of Elmdale, Chase County, Kansas, where the road winds up the hill.

Locality 139.-Kellett's (1933) locality no. 67. Shale above the fusulinid limestone. Thick section exposed near the Cottonwood River bridge east of Elmdale, Chase County, Kansas, where the road winds up the hill.

Locality 140.-Kellett's (1933) locality no. 71. On Highway 50N, four miles north of Burlingame, Osage County, Kansas.

Locality 141.-Kellett's (1933) locality no. 21B. Sample collected from partings in thinly-bedded but very thick limestone at the top of the hill on Highway 32, above Kansas River and Union Pacific Railroad, one-quarter mile west of Linwood, Leavenworth County, Kansas.

Locality 142.-Croneis and Thurman's (1939) locality no. K1; Illinois State Geological Survey locality no. 0419.50 P55 (41/2). Limestone and shale in railroad cut three miles east of Simpson, Pope County, Illinois.

Locality 143.-Croneis and Thurman's (1939) locality K2; Illinois State Geological Survey locality no. 0419.91 P56 (A). Shale outcrop, ten feet thick, in road half a mile southeast of Robbs, Pope County, Illinois. Fossiliferous shale at top.

Locality 144.-Croneis and Thurman's (1939) locality K3; Illinois State Geological Survey locality no. 0428.75 P51B. Limestone, 
coal, fossiliferous shale, and sandstone, in draw three-quarters of a mile southeast of Glendale, Pope County, Illinois.

Locality 145.-Croneis and Thurman's (1939) locality K4; Illinois State Geological Survey locality no. 0520.76 P65A. Fossiliferous, yellow shale with white calcareous nodules, in road one-half mile south of Veach School, Johnson County, Illinois.

Locality 146.-Croneis and Thurman's (1939) locality K5; Illinois State Geological Survey locality no. 0521.47 P65T. Limestone and shale in ravine one mile northwest of Bloomfield, Johnson County, Illinois.

Locality 147.-Croneis and Thurman's (1939) locality K6; Illinois State Geological Survey locality no. 0523.11 P69 (A). Fossiliferous gray clay shale along road 11/4 miles east of Bloomfield, Johnson County, Illinois.

Locality 148.-Croneis and Thurman's (1939) locality K7; Illinois State Geological Survey locality no. 0524.0(?) P71 (A). Yellow shale soft, sticky, and fossiliferous, one-quarter mile east of old Whiteside School, Johnson County, Illinois.

Locality 149.-Croneis and Thurman's (1939) locality K8; Illinois State Geological Survey locality no. 0524.84 P70 3. In creek three-quarters of a mile northeast of Whiteside School, Johnson County, Illinois.

Locality 150.-Croneis and Thurman's (1939) locality K9; Illinois State Geological Survey locality no. 0535.SW4 P39 H. Presumably in SW 1/4, sec. 35, about two miles southeast of Bloomfield, Johnson County, Illinois.

Locality 151.-Croneis and Gale's (1939) locality G1; Illinois State Geological Survey locality no. 0225.70 P10 Sp.A. Limestone and shale in road cut near Douglas School, Hardin County, Illinois.

Locality 152.-Croneis and Gale's (1939) locality G2; Illinois State Geological Survey locality no. 0726.82. In old quarry west of railroad track in SE 1/4, sec. 26, 31/4 miles southeast of Waltersburg, Pope County, Illinois.

Locality 153.-Croneis and Gale's (1939) locality G3; Illinois State Geological Survey locality 0705.90. Presumably in bluff, west 
bank of Lusk Creek, two miles north of Waltersburg, Pope County, Illinois.

Locality 154.-Croneis and Gale's (1939) locality G4; Illinois State Geological Survey locality no. 0414.56 P26 I. Exposure where Brushy Fork cuts west bank just north of center of sec. 14, two miles northwest of Hicks, Hardin County, Illinois.

Locality 155.-Croneis and Gale's (1939) locality G5; Illinois State Geological Survey locality no. 0616.88 P13 Sp.D. Shale, light gray, fossiliferous, NE 1/4, sec. 16, T. 12S., R. 7E., Hardin County, Illinois.

Locality 156.-Croneis and Gale's (1939) locality G6; Illinois State Geological Survey locality no. 0324.04 P15 Sp.C. In road cut 11/4 miles northeast of Grass, Hardin County, Illinois. Sample from shaly limestone with thin shale layers.

Locality 157.-Croneis and Gale's (1939) locality G7; Illinois State Geological Survey locality no. W.595. Southwest of Ruma, Randolph County, Illinois. Designation of the number "W.595" to Illinois State Geological Survey is probably incorrect.

Locality 158.-Croneis and Bristol, 1939, list the locality as Illinois State Geological Survey locality no. “022814 no. 7(C)." Letter "(C)" refers to a preliminary crude sorting by shape that does not identify the locality. The "No. 7" refers to sample or bottle number of which the Illinois State Geological Survey has no longer any record. No. "022814" refers to Carbondale Quadrangle, Union County, Illinois. SE $1 / 4$ SW $1 / 4$ sec. $28, T$ 11S., R. $1 \mathrm{~W}$. Upper Menard. Beginning at top of small scarp or water-fall of Palestine Sandstone on south side of road. The sandstone forms one side of fault. Down creek down section. J. E. Lamar locality.

Locality 159.-Croneis and Bristol, 1939, list the locality as Illinois State Geological Survey locality no. "061972 No. A." No explanation of the number is available on file at the Illinois Geological Survey, hence the locality is considered as unknown.

Locality 160.-Croneis and Bristol, 1939, list the locality as Illinois State Geological Survey locality "P66A 0431.92." No explanation of this number exists on file at the Illinois State Geological Survey, hence the locality has to be considered as unknown. 
Locality 161.-Croneis and Bristol, 1939, list the locality as Illinois State Geological Survey locality "C6(D)." Letter "(D)" refers to a preliminary crude sorting by shape that does not identify the locality. "C6" is the same as locality 158.

Locality 162.-Croneis and Bristol, 1939, list the locality as Illinois State Geological Survey locality "022814 No. 5." "No. 5" refers to sample or bottle numbers of which the Illinois State Geological Survey has no longer any records. "022814" is the same as locality 158.

Locality 163.-Croneis and Bristol, 1939, list the locality as Illinois State Geological Survey locality no. "C6(F)." Letter " $(F)$ " refers to a preliminary crude sorting by shape that does not identify the locality. "C6" is the same as locality 158 .

Locality 164.-Croneis and Bristol, 1939, list the locality as Illinois State Geological Survey locality no. "P51A 0803.49." Number "P51A" equals page 51, sample A in Workman's notebook 550. Number “0803.49" refers to Brownfield Quadrangle, Pope County, Illinois. NE $1 / 4$ NW $1 / 4$ sec. 3, T. 13S., R. 5E. Menard Shale. Top of Menard just below house east of road. L. E. Workman locality.

Locality 165.-Croneis and Bristol, 1939, list the locality as Illinois State Geological Survey locality no. "M 022814 No. 11 (F)." The "No. 11" refers to sample or bottle number of which the Illinois State Geological Survey has no longer any record. The letter " $(\mathrm{F})$ " refers to a preliminary crude sorting by shape, and does not identify the locality. Letter "M" stands for Menard. "022814" is the same as locality 158 .

Locality 166.-Croneis and Bristol, 1939, list the locality as Illinois State Geological Survey locality no. "C6 (c)." Letter "(c)" refers to a preliminary crude sorting by shape and does not identify the locality. "C6" is the same as locality 158.

Locality 167.-Croneis and Bristol, 1939, list the locality as Illinois State Geological Survey locality no. "022814 No. 1 (F)." The "No. 1" refers to sample or bottle number of which the Illinois State Geological Survey has no longer any record. The letter "(F)" refers to a preliminary crude sorting by shape, and does not identify the locality. No. "022814" is the same as locality 158 . 
Locality 168.-Croneis and Bristol, 1939, list the locality as Illinois State Geological Survey locality "Sec. 20 S.E. 1/4." The information about this locality as published is too incomplete to locate on file at the Illinois State Geological Survey. The locality is here considered as unknown.

Locality 169.-Croneis and Bristol, 1939, list the locality as Illinois State Geological Survey locality "Sec. 18RC/M." No explanation of this locality is available on file at the Illinois State Geological Survey. The locality is here considered as unknown.

Locality 170.-Croneis and Bristol, 1939, list the locality as Illinois State Geological Survey locality no. "022814 No. 11 (E)." The "No. 11" refers to sample or bottle number of which the Illinois State Geological Survey has no longer any record. The letter "(E)" refers to a preliminary crude sorting by shape, and it does not identify the locality. No. "022814" is the same as locality 158.

Locality 171.-Croneis and Bristol, 1939, list the locality as Illinois State Geological Survey locality "P66A 0931.92." No explanation of this number exists on file at the Illinois State Geological Survey, hence the locality has to be considered as unknown.

Locality 172.-Croneis and Bristol, 1939, list the locality as Illinois State Geological Survey locality no. "022814 No. 5 (b)." The "No. 5" refers to sample or bottle number of which the Illinois State Geological Survey has no longer any record. The letter "(b)" refers to a preliminary crude sorting by shape, and does not identify the locality. No. "022814" is the same as locality 158.

Locality 173.-Croneis and Bristol, 1939, list the locality as Illinois State Geological Survey locality no. "C6(b)." Letter “(b)" refers to a preliminary crude sorting by shape and does not identify the locality. "C6" is the same as locality 158.

Locality 174.- Croneis and Bristol, 1939, list the locality as Illinois State Geological Survey locality no. "022814 No. 13 (b)." The "No. 13" refers to sample or bottle number of which the Illinois State Geological Survey has no longer any record. The letter "(b)" refers to a preliminary crude sorting by shape, and does not identify the locality. No. "022814" is the same as locality 158. 
Locality 175.-Croneis and Bristol, 1939, list the locality as Illinois State Geological Survey locality no. "022814 No. 7 (b)." The "No. 7" refers to sample or bottle number of which the Illinois State Geological Survey has no longer any record. The letter "(b)" refers to a preliminary crude sorting by shape, and it does not identify the locality. No. "022814" is the same as locality 158.

Locality 176.-Croneis and Bristol, 1939, list the locality as Illinois State Geological Survey locality no. "C4(C)." The letter "(C)" refers to a preliminary crude sorting by shape and does not identify the locality. "C4" refers to Carbondale Quadrangle, Union County, Illinois. SW $1 / 4$ SW $1 / 4$ sec. 29 , T. 11S., R. 1W. Upper Menard. Abandoned quarry along road. J. E. Lamar locality.

Locality 17\%.-Croneis and Bristol, 1939, list the locality as Illinois State Geological Survey locality no. "C6(C)." Letter " $(\mathrm{C})$ " refers to a preliminary crude sorting by shape that does not identify the locality. "C6" is the same as locality 158.

Locality 178.- - Listed as Illinois State Geological Survey locality no. 022814 No. 11 (D). Letter "(D)" refers to a preliminary crude sorting by shape that does not identify the locality. The "No. 11" refers to sample or bottle number of which the Illinois State Geological Survey has no longer any record. No. "022814" is the same as locality 158.

Locality 179.-Listed as Illinois State Geological Survey locality no. $\mathrm{C} 6(\mathrm{E})$. Letter "(E)" refers to a preliminary crude sorting by shape that does not identify the locality. Number " $\mathrm{C} 6$ " is the same as locality 158.

Locality 180.-Croneis and Gutke, 1939, list the locality as Illinois State Geological Survey locality no. ".0526.41 P29.Q." Number "P29" refers to page 29 in Workman's notebook 550; letter "Q" refers to bed in Workman's section. Number ".0526.41" refers to Golconda Quadrangle, Hardin County, Illinois. SE 1/4 SW 1/4 sec. 26, T. 12S., R. 7E. Section of Renault above Union School in roadcut, beds dipping somewhat to north. L. E. Workman locality.

Locality 181.-Croneis and Gutke, 1939, list the locality as Illinois State Geological Survey locality no. "45.9W602.74." In the Illinois State Geological Survey the locality reads "corrected=1102.74. Very much garbled. 4S., 9W., sec. 2 Renault Quadrangle, Monroe 
County, Illinois. NW 1/4 SE $1 / 4$ sec. 2, T. 4S., R. 9W. Renault limestone in old quarry in steep ravine one mile $\mathrm{N}$. of Lohrberg School."

Locality 182.-Croneis and Gutke, 1939, list the locality as Illinois State Geological Survey locality no. ".0905.52D." Golconda Quadrangle, Hardin County, Illinois. SE $1 / 4$ SW 1/4 sec. 5, T. 13S., R. 8E. Section of Renault-Shetlerville in cliff above Ohio River at place where railroad spur runs down into river, east of Extension Shaft. Letter "D" refers to sample " $D$ " in Workman's section. L. E. Workman locality.

Locality 183.-Croneis and Gutke, 1939, list the locality as Illinois State Geological Survey locality no. ".0511.51." This is Golconda Quadrangle, Hardin County, Illinois. SE 1/4 SW 1/4 sec. 11, T. 12S., R. 7E. Renault Shale, roadside below top of knob. L. E. Workman locality.

Locality 184.-Croneis and Gutke, 1939, list the locality as Illinois State Geological Survey locality no. “.0526.42." According to Illinois State Geological Survey this locality is corrected to "0526.52" Golconda Quadrangle, Hardin County, Illinois. SE 1/4 SW 1/4 sec. 26, T. 12S., R. 7E. Sample shale from Renault-Shetlerville 500 feet south of Union School in roadcut, west side. L. E. Workman locality.

Locality 185.- - Listed as Illinois State Geological Survey locality no. .0908.56A. According to Illinois State Geological Survey, it is corrected to 0905.52. Section of Renault-Shetlerville in steep slope above locality 182. Letter "A" refers to a sample in Workman's section. L. E. Workman locality. According to Geis, Journal of Paleontology, vol. 10 , p. 448 , the locality is: "NW 1/4 SW 1/4 NE $1 / 4$ sec. 8 , T. 13S., R. 8E."

Locality 186.-Illinois State Geological Survey locality no. .0526.52. Same as locality 184.

Locality 18\%.-Croneis and Funkhouser's (1939) locality C1. Illinois State Geological Survey locality no. 0619.20 P71-4. Limestone and shale in ravine north of road one mile east of Whiteside School, Johnson County, Illinois. 
Locality 188.-Croneis and Funkhouser's (1939) locality C2. Illinois State Geological Survey locality no. 0311.73 P15-Sp.A. Shale, gray, sandy and fossiliferous near bottom, exposed in road cut south of Loves Store, 700 feet north of Philadelphia School, Hardin County, Illinois.

Locality 189.-Croneis and Funkhouser's (1939) locality C3. Illinois State Geological Survey locality no. 0619.20 No. 4. Essentially same location as locality 187.

Locality 190.-Croneis and Funkhouser's (1939) locality C4. Illinois State Geological Survey locality no. 05A19.06 25 (A). Along road and Whiteside Branch of Hayes Creek four miles east and one-half mile north of Glendale, Pope County, Illinois.

Locality 191.-Kellett's (1933) locality no. 17. Railroad cut by Kansas River just west of the Shawnee-Douglas County line crossing Highway 10. In Shawnee County, Kansas.

- Locality 192.-Kellett's (1933) locality no. 23. U. S. Highway 73E, two miles south of Lansing by Nine Mile School, District No. 17, Leavenworth County, Kansas.

Locality 193.-Kellett's (1933) locality no. 24. Gray limestone in road cut about 600 feet south of the Missouri River Bridge at the Fort Leavenworth Military Reservation. Leavenworth County, Kansas.

Locality 194. - Kellett's (1933) locality no. 34. Abandoned quarry in SW $1 / 4$ of sec. 7, T. 12S., R. 16E., on Shriner road just east of Highway 73, south of Topeka, Kansas.

Locality 195.--Kellett's (1933) locality no. 40. A rather massive, gray limestone, three feet thick, and containing many pelecypods; road cut at foot of hill in Wabaunsee County, about one mile south of Wamego, Kansas, but across the Kansas River on Kansas State Highway 29. This limestone is the first prominent one outcropping along the road west of the German Lutheran Church.

Locality 196.-Kellett's (1933) locality no. 47. Small quarry in road cut of Highway 40, about four miles west of Junction City, Kansas. This quarry is at the north side of the road. 
Locality 197.-Kellett's (1933) locality no. 60. Massive limestone about eight feet thick, exposed below the road and up-stream near the bridge. There is a thin shale parting about the middle, below which fusulinids are abundant. Ostracodes collected from this shale parting and from the shale on top of the limestone are beautifully preserved, many showing the muscle spots on the interior of the valves. This is a thick section exposed near the Cottonwood River bridge east of Elmdale, Chase County, Kansas, where the road winds up the hill.

Locality 198.-Kellett's (1933) locality no. 60X. This includes several collections from the limestones and shales collected a little farther upstream than locality 197 (Kellett's 60), at the place where there is a prominent Fusulina-limestone at the water level. The several collections of $60 \mathrm{X}$ were made in the limestones and shales above the water level and below the road. Localities 60 and $60 \mathrm{X}$ are in part equivalent horizons.

Locality 199.-Kellett's (1933) locality no. 61. A thick section exposed near the Cottonwood River bridge east of Elmdale, Chase County, Kansas, where the road winds up the hill.

Locality 200.-Kellett's (1933) locality no. 65. A lighter-colored shale continuing above the carbonaceous shale, where the road bends about half-way up the hill. Section exposed near the Cottonwood River bridge east of Elmdale, Chase County, Kansas.

Locality 201.-Kellett's (1933) locality no. 72. Outcrop along road just east of Scranton, Osage County, Kansas. About five feet of shale is exposed below limestone.

Locality 202.-Kellett's (1935) locality no. 78. Along U. S. Highway 166, three miles west of Sedan, Chautauqua County, Kansas, in sec. 5, T. 34S., R. 11E. Beside the ostracodes many small gastropods were present in the fauna.

Locality 203.-Nodular zone, 52 feet below the top of the dolomite as exposed in the Federal Stone Company Quarry at the western limits of Chicago, Illinois. The nodules have a vertical extent of about three feet and a sporadic lateral occurrence of about 400 feet.

Locality 204.-Kellett's (1929) locality no. 25. Brick plant cut, north of Gage Park, Topeka, Kansas. 
Locality 205.-Kellett's (1929) locality no. 40. Road cut at foot of hill about one mile west of Belvue, Wamego County, Kansas.

Locality 206.-Kellett's (1929) locality no. 42. South of State Agricultural School, Manhattan, Kansas.

Locality 207.-Kellett's (1929) locality no. 65. Exposure in bluff along Cottonwood Falls River at bridge east of Elmdale, Chase County, Kansas.

Locality 208.-Kellett's (1929) locality 45. On Highway 40 opposite cemetery, Fort Riley, Geary County, Kansas.

Locality 209.-Mabelle Draw locality. One-half mile east from the point on U. S. Highway 283 three miles north of the intersection at Mabelle; along a fork of Mitchell Creek in northeast portion of Baylor County, Texas.

Locality 210.-Olson Collection. Near La Salle, La Salle County, Illinois.

Locality 211.-Olson Collection. SW 1/2, Sec. 15, T. 7N., R. 3E., about $31 / 2$ miles south-east of Falmouth, Jasper County, Illinois.

Locality 212.-Bassler Collection. In the Lawrence Shale. Lawrence, Kansas.

Locality 213.-Weller Collection. S. Weller's (1916, p. 244) locality. Arenaceous, oölitic limestone bed, no. 8 in a rock gorge on Fountain Creek, two miles southwest of Waterloo, Monroe County, Illinois.

Locality 214.-Bassler Collection. Near Waldron, Indiana.

Locality 215.-Weller Collection. S. Weller's (1903, p. 71) locality 109B. The lower beds of the Decker Ferry Formation resting directly on the Bossardville limestone; containing large amounts of arenaceous material with intercalated calcareous highly fossiliferous beds; the commonest species being Chonetes jerseyensis Weller. Along the creek below the lime kiln at Flatbrookville, New Jersey.

Locality 216.-Bassler Collection. Limestones interbedded in shaly slates two miles southeast of North Granville, Washington County, 
New York. Walcott (1890) cites the same locality as two miles southeast of North Greenwich, Washington County, New York.

Locality 217.-Bassler Collection. Limestones interbedded in shaly slates on a ridge east of Troy, New York and at the lowest fossiliferous horizon, one-half mile west of North Greenwich, Washington County, New York.

Locality 218.-Bassler Collection. Walcott (1877, p. 193) lists the following localities: (a) north part of Easton one mile south of Greenwich; (b) one and one-half miles west of North Greenwich; (c) three miles northeast and one and one-half miles east of North Greenwich; (d) one mile S.S.E. of Battenville in the town of Jackson. All these localities are in limestones interbedded in shaly "Taconic slate" in Greenwich township in Washington County, New York.

Locality 219.-Bassler Collection. It may be either in a boulder near Sunset Hill, near Lake Dunmore, Vermont, or in situ in quartzite east of Bennington, Vermont. Museum catalog locality is Stissing Mt., Dutchess County, New York.

Locality 220.-Bassler Collection. One mile below Argenta in Big Cottonwood Canyon, Wasatch Mountains, Utah.

Locality 221.- Hall Collection. In literature (Hall, 1872, p. 232) given as Cincinnati, Ohio; but specimen bears original label giving locality as Oxford, Ohio.

Locality 222.-Bassler Collection. Marion County, Kentucky.

Locality 223.-Weller Collection. S. Weller's (1903, p. 42) locality 137A. Two miles southeast of Newton, and one-half mile northwest of Iliff's pond, New Jersey.

Locality 224.-Faber Collection. Versailles, Indiana.

Locality 225.-Bassler Collection. Near Harrodsburg, Kentucky.

Locality 226.-Bassler Collection. At Savannah, Illinois.

Locality 227.-Faber Collection. Under the bank of the Ohio River at 7-14 feet above low watermark in the First Ward of Cincinnati, Ohio. 
Locality 228.-Bassler Collection. At Queen Spring Hill, Schell Creek Range, Nevada.

Locality 22.9.-Bassler Collection. In siliceous limestones near top of the Trenton Limestone at Danville, Kentucky.

Locality 230.-Faber Collection. On the I. C. R. R. in limestone slabs associated with Beyrichia quadrilirata, "about 300 feet below the Upper Silurian." Three miles east of Weisburg, Ohio.

Locality 231.-Bassler Collection. At the top of the gorge, High Bridge, Kentucky.

Locality 232.-Bassler Collection. In Division 1, Band d at Dugald Brook, Escasonie, Nova Scotia.

Locality 233.-Faber Collection. "Near the top of the hills of Cincinnati"; Ohio.

- Locality 234.-Faber Collection. 430 feet above low watermark; at the top of Vine Street hill, in Cincinnati, Ohio.

Locality 235.-Faber Collection. Near Wilmington, Clinton County, Ohio.

Locality 236.-Bassler Collection. Found associated with Leperditia linneyi. At Perryville, Kentucky.

Locality 237.-Bassler Collection. An erratic block of limestone found in Sussex Street, Ottawa, Canada.

Locality 238.-Bassler Collection. At Blind Asylum, Nashville, Tennessee.

Locality 239.- Bassler Collection. In Division 1, Band b at Hanford Brook, St. Martins, New Brunswick, Canada.

Locality 240.-Bassler Collection. In Division 1, Band d at Boundary Brook, Escasonie, Nova Scotia, Canada.

Locality 241.-Bassler Collection. In Division 1, Band c at Dugald Brook, Escasonie, Nova Scotia, Canada. 
Locality 242.-Bassler Collection. Division 1, Band b of the St. John Group as found in the valley of the Kennebecasis River on the southern shore of Long Island on Kennebecasis Bay, Nova Scotia, Canada.

Locality 243.-Roy Collection. Silliman's Fossil Mount. At the west side of the terminus of the bay, about 300 feet from high tide and $21 / 2$ miles south of the Jordan River. It is a longitudinal mount of horizontally-bedded limestone which lies unconformably on the rocks of the hills of Meta Incognita. $63^{\circ} 43^{\prime} \mathrm{N}$. Lat., and $69^{\circ} 2^{\prime}$ W. Long. Frobisher Bay, Baffin Land, Canada. 


\section{REFERENCES}

BAssler, R. S.

1913. Revision of the Ostracoda, pp. 735-742, text-figs. 1423-1436. In Zittel, K. A. von and C. R. Eastman. Textbook of Palaeontology, 2d ed., vol. 1, London.

1915. Bibliographic index of American Ordovician and Silurian fossils, 2 vols., Smithsonian Inst. U. S. Nat. Mus., Bull. 92, 1521 pp.

1927. Ostracoda, pp. 340-350. In Twenhofel, W. H. Geology of Anticosti Island. Geol. Surv. Canada, Mem., 154.

BASSLER, R. S. and B. KELletT

1934. Bibliographic Index of Paleozoic Ostracoda. Geol. Soc. Am., Special Papers, no. 1; 500 pp., 24 figs., tables.

Chernysheva, N. E., ed.

1960. Arthropods-trilobitomorphs and crustaceans. Vol. 8, Osnovy paleontologii, Moscow, USSR. 515 pp., 18 pls., 1318 text figs.

COOPER, C. L.

1941. Chester Ostracodes of Illinois. Ill. State Geol. Surv., Rept. Investigations, no. 77, 101 pp., 14 pls.

1946. Pennsylvanian Ostracodes of Illinois. Ill. State Geol. Surv. Bull., no. 70, 177 pp., 21 pls., 31 text figs.

1947a. Upper Kinkaid (Mississippian) Microfauna from Johnson County, Illinois. Jour. Paleontol., 21, pp. 81-94, pls. 19-23.

1947b. Upper Kinkaid (Mississippian) Microfauna from Johnson County, Illinois. Ill. State Geol. Surv., Rept. Investigations, no. 122,13 pp., 5 pls.

Coryell, H. N. and D. S. MALKIN

1936. Some Hamilton Ostracodes from Arkona, Ontario. Am. Mus. Novitates, no. 891,20 pp., 2 pls.

Croneis, C.

1939. Taxonomy of Chester Ostracodes. Denison Univ. Bull., Jour. Sci. Lab., 34, pp. 28-32.

Croneis, C. and H. M. Bristol

1939. New Ostracodes from the Menard Formation. Denison Univ. Bull., Jour. Sci. Lab., 34, pp. 65-102, pls. 3-4.

1942. Denisonella, New name for Denisonia. Jour. Paleont., 16, no. 6, p. 777.

Croneis, C. and H. J. Funkhouser

1939. New Ostracodes from the Clore Formation. Denison Univ. Bull., Jour. Sci. Lab., 33, pp. 331-360, pls. 9-10.

Croneis, C. and A. S. Gale, JR.

1939. New Ostracodes from the Golconda Formation. Denison Univ. Bull. Jour. Sci. Lab., 33, pp. 251-295, pls. 5-6.

Croneis, C. and R. L. Gutke

1939. New Ostracodes from the Renault Formation. Denison Univ. Bull., Jour. Sci. Lab., 34, pp. 33-63, pls. 1-2. 
Croneis, C. and F. A. Thurman

1939. New Ostracodes from the Kinkaid Formation. Denison Univ. Bull., Jour. Sci. Lab., 33, pp. 297-330, pls. 7-8.

Cummings, R. E.

1908. Stratigraphy and Paleontology of the Ordovician rocks of Indiana. Geol. Surv. Indiana, 32 nd Ann. Rep., pp. 605-1188, 55 pls.

Grabau, A. W. and H. W. Shimer

1910. North American Index Fossils. Invertebrates, 2, 909 pp., 726 text-figs., New York.

\section{Grubbs, D. M.}

1939. Fauna of the Niagaran Nodules of the Chicago Area. Jour. Paleontol., 13 , no. 6 , pp. $543-560$, pls. $61-62,2$ text figs.

HALL, J.

1871. Description of some new species of fossils, from the shales of the Hudson River Group, in the vicinity of Cincinnati, Ohio. Published in advance of the 24 th Ann. Rept., N. Y. State Cab. Nat. Hist., 8 pp., 2 pls.

1872. Description of new species of fossils from the Hudson River Group, in the vicinity of Cincinnati, Ohio. 24th Ann. Rept., N. Y. State Cab. Nat. Hist., pp. 225-232, pls. 7-8.

HALL, J. and R. P. WHITFIELD

1875. Fossils of the Hudson River Group (Cincinnati Formations). Geol. Surv. Ohio Rept., 2, Geol. Palaentol., part 2, Palaentol., pp. 67-110, 4 pls.

HuSSEY, R. C.

1926. The Richmond Formation of Michigan. Univ. Michigan, Mus. Geol. Contrib., 2, no. 8, pp. 118-187, 11 pls., 12 text-figs.

JONES, T. R.

1884. Notes on the palaeozoic bivalved Entomostraca.--No. XVII. Some North American Leperditae and allied forms. Ann. Mag. Nat. Hist., ser. 5, 14, pp. 339-347.

1890. On some Palaeozoic Ostracoda from North America, Wales and Ireland. Quart. Journ. Geol. Soc. London, 46, pp. 1-31, pls. 1-4, 2 text-figs.

KELLETT, B.

1929. The Ostracode genus Hollinella, expansion of the genus and description of some Carboniferous species. Jour. Paleontol., 3, pp. 196-217, pls. 25-26.

1933. Ostracodes of the Upper Pennsylvanian and the Lower Permian Strata of Kansas: I. The Aparchitidae, Beyrichiidae, Glyptopleuridae, Kloedenellidae, Kirkbyidae, and Youngiellidae. Jour. Paleontol., 7, no. 1, pp. 59-108, pls. $13-16$.

1934. Ostracodes from the Upper Pennsylvanian and the Lower Permian Strata of Kansas: II. The genus Bairdia. Jour. Paleontol., 8, no. 2, pp. 120-138, pls. $14-19$.

1935. Ostracodes of the Upper Pennsylvanian and the Lower Permian Strata of Kansas: III Bairdiidae (concluded), Cytherellidae, Cypridinidae, Entomoconchidae, Cytheridae and Cypridae. Jour. Paleontol., 9, no. 2, pp. 132-166, pls. $16-18$.

1936. Carboniferous Ostracodes. Jour. Paleontol., 10, no. 8, pp. 769-784.

KeSLiNG, R. V.

1952. Ostracods of the families Leperditellidae, Primitiidae, Drepanellidae, Aechminidae, and Kirkbyidae from the Middle Devonian Bell Shale of Michigan. Contr. Mus. Paleontol., Univ. Michigan, 10, no. 2, pp. 21-44, 5 pls. 
Kesling, R. V. and J. E. Kilgore

1952. Ostracods of the families Leperditellidae, Drepanellidae, Glyptopleuridae, Kloedenellidae, Bairdiidae, Barychilinidae, and Thlipsuridae from the Genshaw Formation of Michigan. Contr. Mus. Paleontol., Univ. Michigan, 10 , no. 1 , pp. 1-19, 4 pls.

Kesling, R. V. and M. Weiss

1953. Ostracods from the Norway Point Formation of Michigan. Contr. Mus. Paleontol., Univ. Michigan, 11, no. 3, pp. 33-76, 5 pls.

LEVINSON, S. A.

1950. The hingement of Paleozoic Ostracoda and its bearing on orientation. Journ. Paleontol., 24, no. 1, pp. 63-75, 16 text-figs.

1951. Thin sections of Paleozoic Ostracoda and their bearing on taxonomy and morphology. Journ. Paleontol., 25, no. 5, pp. 553-560, pl. 77, 1 text-fig.

Matthew, G. F.

1886. Illustrations of the fauna of the St. John Group continued. No. IIIDescription of new genera and species (including a description of a new species of Solenopleura by J. F. Whiteaves). Trans. Roy. Soc. Canada, 1885, 3, sec. 4 , pp. 29-84, pls. 5-7.

1894. Illustrations of the Fauna of the St. John Group. No. VIII. Trans. Roy. Soc. Canada, 1893, 11, sec. 4, pp. 85-130, pls. 16-17.

1895. The Protolenus Fauna. Trans. N. Y. Acad. Sci., 14, pp. 101-153, 11 pls.

1898. Studies on Cambrian Faunas No. 2. Proc. and Trans. Roy. Soc. Canada, ser. 2,4 , sec. 4 , pp. $123-153,2$ pls.

1902. Ostracoda of the basal Cambrian rocks in Cape Breton. Canadian Rec. Sci., 8, pp. 437-470, 2 pls.

1903. Report on the Cambrian Rocks of Cape Breton. Geol. Surv. Canada, 246 pp., 18 pls., numerous text-figs.

Miller, S. A.

1874. Monograph of the Crustacea of the Cincinnati Group. Cincinnati Quart. Jour. Sci., 1, no. 2, pp. 115-147, text-figs. 10-11.

1874a. Beyrichia duryi. Cincinnati Quart. Jour. Sci., 1, no. 3, pp. 232-233, text-figs. 24-25.

1874b. Beyrichia richardsoni. Cincinnati Quart. Jour. Sci., 1, no. 4, pp. 347348, text-fig. 40.

1875. Some new species of fossils from the Cincinnati Group and remarks upon some described forms. Cincinnati Quart. Jour. Sci., 2, no. 4, pp. 349-355, text-figs. $23-25$.

1878. Description of a new genus and eleven new species of fossils, with remarks upon others well known, from the Cincinnati Group. Jour. Cincinnati Soc. Nat. Hist., 1, pp. 100-108, pl. 3.

1881. Description of new species of fossils. Jour. Cincinnati Soc. Nat. Hist., 4, no. 3 , pp. 259-262, pl. 6 .

1882. Description of three new species and remarks upon others. Jour. Cincinnati Soc. Nat. Hist., 5, no. 3, pp. 116-117, pl. 5.

1889. North American geology and palaeontology for the use of amateurs, students, and scientists. $664 \mathrm{pp} .$, numerous text-figs. Cincinnati, Ohio.

1897. North American geology and palaeontology, 2nd Appendix, pp. 719-793, numerous text-figs.

Miller, S. A. and C. L. FABer

1894. Description of some Cincinnati fossils. Jour. Cincinnati Soc. Nat. Hist., 17 , no. 3 , pp. $137-158$, pls. $7-8$. 
MOORE, R. C., ed.

1961. Treatise on Invertebrate Paleontology. Part Q; Arthropoda 3 Crustacea Ostracoda. 442 pp., 334 figs.

Olson, E. C.

1946. Fresh and brackish-water vertebrate-bearing deposits of the Pennsylvanian of Illinois. Jour. Geol., 54, pp. 281-305.

Pokorny, V.

1965. Principles of zoological micropalaeontology, Vol. 2. Pergamon Press (Int. series of Monographs on Earth Science, vol. 20). Oxford, London, Edinburgh, New York, Paris, Frankfort. 465 pp., figs. 550-1077.

READ, W. F.

1943. Environmental significance of a small deposit in the Texas Permian. Jour. Geol., 51, pp. 473-487.

RESSER, C. E.

1938. Fourth contribution to nomenclature of Cambrian fossils. Smithsonian Misc. Coll., 97, no. $10,42 \mathrm{pp}$.

RoY, S. K.

1941. The Upper Ordovician fauna of Frobisher Bay, Baffin Land. Field Mus. Nat. Hist., Geol. Mem., 2, 212 pp., 146 text-figs.

SHIMER, H. W. and R. R. SHROCK

1944. Index fossils of North America. John Wiley and Sons, Inc., New York. 837 pp., 303 pls.

SoHN, I. G.

1940. Check list of Mississippian Ostracoda of North America. Jour. Paleontol., 14, pp. 154-160, 1 table.

1954. Ostracoda from the Permian of the Glass Mountains, Texas. U.S. Geol. Surv., Prof. Paper no. 264-A, 24 pp., 5 pls.

STEWART, G. A.

1936. Ostracodes of the Silica Shale, Middle Devonian of Ohio. Jour. Paleontol., 10, no. 8, pp. 739-763, pls. 100-102.

SWAIN, F. M , JR.

1957. Early Middle Ordovician Ostracoda of the Eastern United States. Part I. Stratigraphic data and description of Leperditiidae, Aparchitidae and Leperditellidae. Jour. Paleontol., 31, no. 3, pp. 528-570, pl. 59-62, 10 text-figs.

Swartz, F. M.

1936. Revision of the Primitiidae and Beyrichiidae, with new Ostracoda from the Lower Devonian of Pennsylvania. Jour. Paleontol., 10, no. 7, pp. 541586 , pl. $78-89$.

ULRICH, E. O.

1890. New and little known American Paleozoic Ostracoda. Jour. Cincinnati Soc. Nat. Hist., 13, no. 3, pp. 104-137, pls. 7-10.

1891. New and little known American Paleozoic Ostracoda. Jour. Cincinnati Soc. Nat. Hist., 13, no. 4, pp. 173-211, pls. 11-18.

1892. New Lower Silurian Ostracoda, no. 1. Am. Geol., 10, no. 5, pp. 263-270, pl. 9 .

1897. The Lower Silurian Ostracoda of Minnesota. Geol. Minn., 3, pt. 2, pp. 629-693, pls. 43-46, text-figs. 46-52.

ULRICH, E. O. and R. S. BASSLER

1906. New American Ostracoda. Notes and descriptions of Upper Carboniferous genera and species. Proc. U. S. Nat. Mus., 30, pp. 149-164, pl. 11. 
1908. New American Paleozoic Ostracoda. Preliminary revision of the Beyrichiidae with descriptions of new genera. Proc. U. S. Nat. Mus., 35, pp. 277-340, pls. 37-44, 61 text-figs.

1913. Ostracoda, pp. 513-542 in Maryland Geol. Surv. Lower Devonian Text; pls. 95-98 in Maryland Geol. Surv. Devonian Plates.

1923. Paleozoic Ostracoda: Their morphology, classification and occurrence, pp. 271-391, text-figs. 11-25 in Maryland Geol. Surv. Silurian.

1923a. Arthropoda: Class Crustacea: Superorder Ostracoda, pp. 500-704, pls. 36-95, text-fig. 27 in Maryland Geol. Surv. Silurian.

1931. Cambrian bivalved Crustacea of the order Conchostraca. Proc. U. S. Geol. Surv., 78, art. 4, 130 pp., 10 pls.

VAN Pelt, H. L.

1933. Some ostracodes from the Bell Shale, Middle Devonian of Michigan. Jour. Paleontol., 7, no. 3, pp. 325-342, pl. 39.

WaLCOTT, C. D.

1886. Second contribution to the studies on the Cambrian faunas of North America. Bull., U. S. Geol. Surv., 30, 369 pp., 33 pls.

1887. Fauna of the "Upper Taconic" of Emmons in Washington County, N. Y. Am. Jour. Sci., ser. 3, 34, pp. 187-199, 1 pl.

1890. The fauna of the Lower Cambrian or Olenellus zone. 10th Ann. Rept., U. S. Geol. Surv., pp. 515-658, pls. 49-98.

WARThin, A. S., JR.

1934. Common Ostracoda of the Traverse Group. Contr. Mus. Paleontol., Univ. Michigan, 4, no. 12, pp. 205-226, 1 pl.

- Weller, S.

1903. The Paleozoic Faunas. Geol. Surv. New Jersey Rept., Paleontol., 3, 462 pp., 53 pls.

1916. Description of a Ste. Genevieve Limestone fauna from Monroe County, Illinois. Walker Museum, Paleontol. Contrib., 1, no. 10, pp. 243-265, pls. 16-19.

White, C. A.

1874. Preliminary report upon the invertebrate fossils collected by the expeditions of 1871,1872 and 1873 with descriptions of new species. Geogr. and Geol. Explor. and Surv. west of the 100th meridian. Engineer Dept., U. S. Army, pp. 1-27.

1877. Part I. Report upon the invertebrate fossils collected in portions of Nevada, Utah, Colorado, New Mexico and Arizona by parties of the expeditions of $1871,1872,1873$ and 1874.219 pp., 21 pls. in U. S. Geog. Surv. west of the 100 th meridian, 4.

WiLMARTH, M. G.

1938. Lexicon of geologic names of the United States. Bull. U. S. Geol. Surv., 896,2 vols., $2396 \mathrm{pp}$.

ZiTTEL, K. A. von and C. R. EAstman

1913. Textbook of Palaeontology, 2nd ed., vol. 1, 839 pp., 1594 text-figs., London. 


. 






\section{Publication 1050}







UNIVERSITY OF ILLINOIS-URBANA

$550.5 \mathrm{FI}$

COO

FIELDIANA, GEOLOGY CHGO

$171967 / 68$

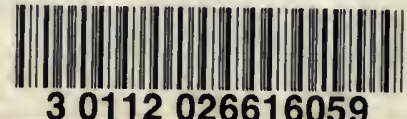

0112026616059 